\title{
A PLAN FOR STUDY OF WATER AND ITS RELATION TO ECONOMIC DEVELOPMENT IN THE GREEN RIVER AND GREAT DIVIDE BASINS IN WYOMING \\ Open-File Report 76-349
}
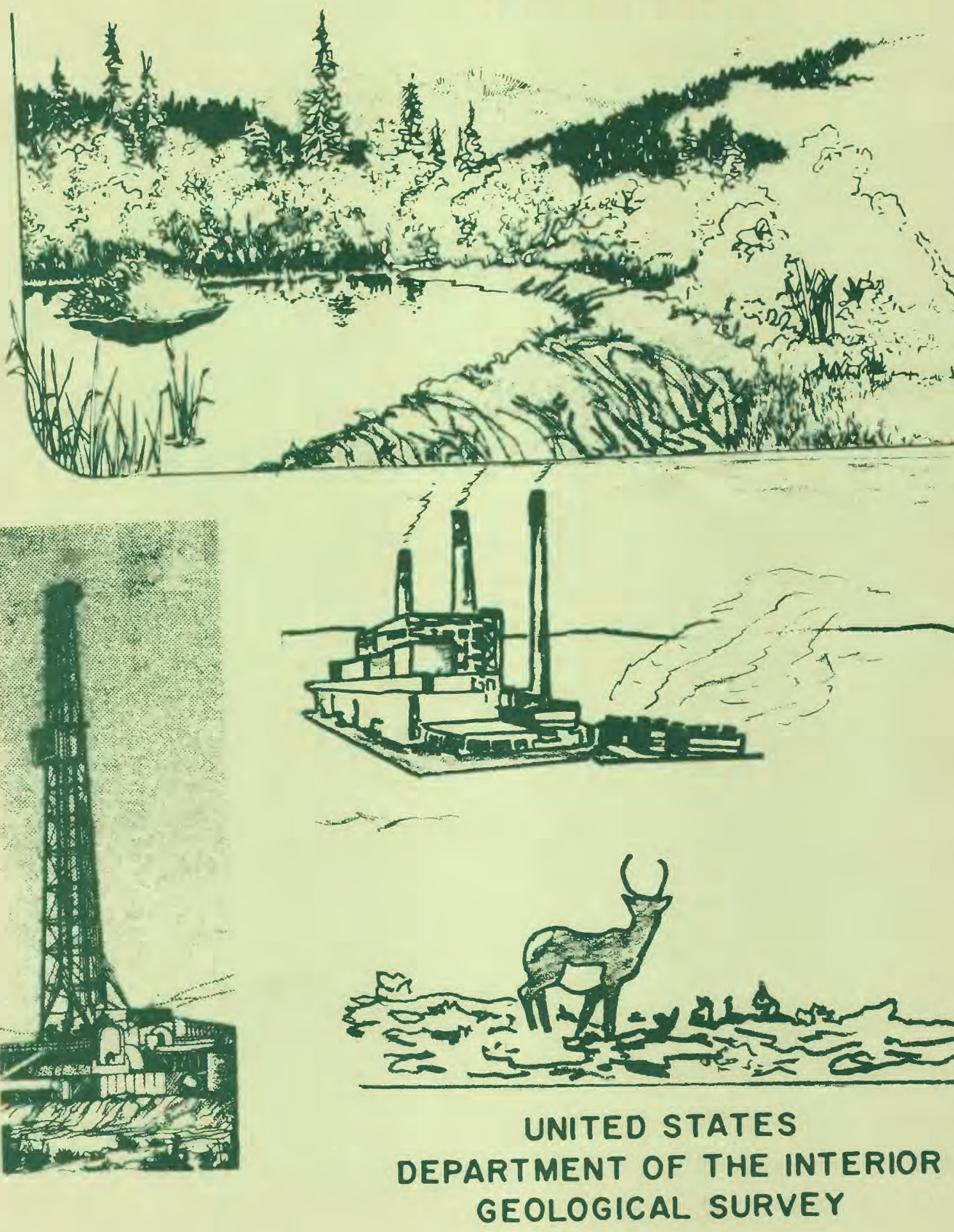
UNITED STATES

DEPARTMENT OF THE INTERIOR

GEOLOGICAL SURVEY

A PLAN FOR STUDY OF WATER AND ITS RELATION TO

ECONOMIC DEVELOPMENT IN THE GREEN RIVER AND

GREAT DIVIDE BASINS IN WYOMING

By H. W. Lowham, L. L. De Long, K. D. Peter, D. J. Wangsness, W. J. Head, and B. H. Ringen

Open-File Report 76-349

Cheyenne, Wyoming 


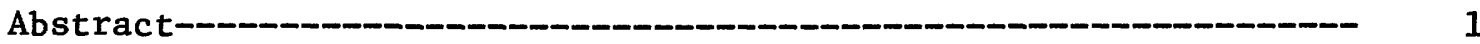

Introduction-

Description of the problem-_- 2

Scope of the investigation-_- 2

Objectives of the study-_- 3

Objectives-_-_- 3

Specific objectives-D- 3

Units of measurement- 3

Well and surface-water station numbering systems--_-_--_ 5

General description of the study area- 6

Location-_- 6

Physiography-1-_-_-_-_- 6

Geology-- 8

Climate--_-_-C_-_- 15

Vegetation-_-_-_-_-_- 21

Land use-- 21

Population and economic base-_- 21

Commerce-_-_-_-_-_- 21

Recreation-_-_-_-_-_-_- 21

Agriculture--_-_-_-_-_-_- 25

Energy mineral resources-_-_-_-_-_-_-_-_-_-_-_ 25

Non-energy minerals-_- 28

Land ownership-_-_-_- 28

Water resources-_- 34

General description of the hydrology-_an 34

Summary of existing data-_- 37

Summary of previous studies-_- 55

Water demands and uses-_-_- 56

Water supplies for future demands-_- 58

Description of the study plan-_- 60

Surface water-_-_- 60

Streamflow-_-_-_-_-_ 60

Chemical quality-_-_- 63

Biological quality-_-_-_- 67

Temperature--_-_-_-_- 67

Sediment-- 69

Channel characteristics-- 71

Ground water--_-_-_- 74

Determination of potential supply-_ 74

Effects of economic development-_-_- 77

Well and spring inventory-_- 78

Borehole geophysics-_- 78

Surface geophysics-_- 78

Drilling and well development-_- 85

Work schedule and report plans- 86

References-_- 87 


\section{ILLUSTRATIONS}

Figure 1. Map showing locations of Green River and Great Divide Basins in Wyoming-_-

2. Map showing location of study area in relation to major structural features of Wyoming--

3. Sketch of schematic section showing stratigraphic relation of the Wasatch, Green River, and Bridger Formations and their members-_-

4-14. Maps showing--

4. Mean annual precipitation-_-

5. Average growing season for forage crops-_-_--- 20

6. Vegetal cover types-_-_- 22

7. Locations of timber industries-_-__-_-_-_ 23

8. Major transportation systems-_-_- 24

9. $0 i 1$ and natural gas fields-_- 26

10. Areas of coal resources-__ 27

11. Locations of uranium mines and areas of major uranium exploration-_-_-_-_-

12. General locations of surface exposures of three oil-shale bearing members of the Green River Formation-_-_-

13. Area underlain by trona beds and locations of trona mines-_-_-_-_-_-_-_-

14. Approximate distribution of 1and ownership--

15. Hydrograph of mean daily discharge at station 09188500 Green River at Warren Bridge, near Danie1, Wyoming (average of 1931-71 water years)-_-__-_-

16. Hydrograph of daily discharge at station 09215000 Pacific Creek near Farson, Wyoming (1971 water year)-- 


\section{ILLUSTRATIONS--continued}

Page

Figure 17-24. Maps showing locations of--

17. Active streamflow and reservoir stations-_-_...

18. Discontinued streamflow and reservoir stations-_-

19. Partial-record gaging stations- 44

20. Chemical and biological quality-of-water sampling stations-

21. Suspended-sediment sampling stations-_-_-_..- 49

22. Observation wel1s- 51

23. Potential water-supply developments that would utilize surface waters--

24. Proposed new gaging stations- 61

25. Hydrograph of mean daily discharge, dissolvedsolids concentration, and dissolved-solids load at station 09188500 Green River at Warren Bridge, near Danie1, Wyoming

26-27. Graphs showing--

26. Relation of daily specific conductance to daily discharge at station 09217000 Green River near Green River, Wyoming (1972 water year)

27. Plot of differences between the simulated and observed values of daily specific conductance at station 09217000 Green River near Green River, Wyoming (1972 water year)

28. Map showing locations of proposed new biological measurement sites 


\section{ILLUSTRATIONS---continued}

Page

Figure 29-33. Graphs showing--

29. Relation of suspended-sediment concentration to discharge at station 09213500 Big Sandy River near Farson, Wyoming-_-

30. Changes of width, mean depth, and mean velocity with discharge at a channel cross section, station 09205500 North Piney Creek near Mason, Wyoming--

31. Stream width, mean depth, and mean velocity in relation to 2-year peak discharge as discharge increases downstream, Green River and tributaries, Wyoming-

32. Cross section of Delaney Draw near Red Desert, Wyoming--

33. Porosity and lithology as determined from an analysis of geophysical well logs-_-_-_---

34. Sketch showing example of surface-resistivity measurements in alluvium compared to drill $10 \mathrm{~g}$ and gamma $10 \mathrm{~g}$ of a nearby hole-

35. Sketch showing interpretations of resistivity measurements in till compared with lithologic $10 \mathrm{~g}$ information-_-_-_-

36. Map showing locations of proposed sites for resistivity studies of alluvial deposits-------

37. Graph showing example seismic section interpreted to show velocity segment analysis, depth, unit thickness, and geologic structure- 


\section{TABLES}

Fage

Table 1. Generalized column of geologic formations-- 10

2. Monthly and annual precipitation normals, in inches, for the period $1941-70$

3. Monthly and annual mean temperatures, in degrees Fahrenheit, for the period 1941-70- 19

4. Land ownership in the Green River and Great Divide Basins- 33

5. Active streamflow and reservoir stations-- 40

6. Discontinued streamflow and reservoir stations-- 42

7. Partial-record gaging stations- 45

8. Chemical and biological quality-of-water sampling stations- 47

9. Suspended-sediment sampling stations-- 50

10. Observation wells- 52

11. Summary of present and projected consumptive water uses in the Green River and Great Divide Basins-- 
A PLAN FOR STUDY OF WATER AND ITS RELATION TO ECONOMIC DEVELOPNFNT

IN THE GREEN RIVER AND GREAT DIVIDE BASINS IN WYOMING

\author{
By H. W. Lowham, L. L. De Long, K. D. Peter, D. J. Wangsness, \\ W. J. Head, and B. H. Ringen
}

\begin{abstract}
Development of extensive coal, oil, gas, trona, and oil-sha..e resources as well as other developments in the Green River and Great Divide Basins will require a projected increase in water consumption of 490,000 acre-ft $\left(600 \mathrm{hm}^{3}\right)$ per year by 2020 . Developments of energy resources in other parts of Wyoming will also require large amounts of water; transbasin diversion of Green River water to other areas could total an additional 270,000 acre-ft $\left(330 \mathrm{hm}^{3}\right)$ per year. In anticipation of this increased demand, water planners and managers need much nore information about available ground and surface waters, present quality of the waters, and hydrologic effects that would be caused by derelopment of energy resources.

The U.S. Geological Survey is conducting an extensive hydrologic study of the basins. This report summarizes the study plan and discusses particular methods of approach that would be utilized in the study. The principal objectives of the study are: 1) To describe the water resources and hydrologic relations that presently exist; 2) to develop predictive methods that can be used to describe future conditions, including reactions to increased water development; and 3) to establish monitoring programs for detecting possible changes in water conditions.

The most up-to-date methods available are being utilized to collect and analyze the hydrologic data. Regarding water quality, particular attention is being given to trace metals, biological characteristics, and trend analyses of salinity. Channel-geometry techniques, detailed statistical analyses, and mathematical models are being applied to surface-water studies. An updated well inventory, aquifer tests, and borehole and surface geophysical surveys are being used in ground-water studies.

Efforts will be made by the U.S. Geological Survey to coordinate this study with the needs of the prospective users of the results, including industries and government agencies.
\end{abstract}




\section{INTRODUCTION}

\section{Description of the Problem}

Water demands in the Green River and Great Divide Basins of W.oming are increasing rapidly due to development of extensive coal, oil, gas, uranium, and trona resources. The potential also exists for future development of extensive oil-shale resources. As these developments proceed, large supplies of water will be needed at widely separatef parts of the basins for recovery and utilization of the resources, for municipal supplies, and for recreation. The importance of water to the economic and social development of the area requires that careful attention be given to planning for the optimum control, conservation, and use of this resource.

Water planners and managers need much more information than is now available concerning ground and surface waters, present quality of the waters, and hydrologic effects caused by development of mineral resources.

\section{Scope of the Investigation}

The U.S. Geological Survey is conducting a study of water resources in the Green River and Great Divide Basins. The study began in Norember 1974 and is scheduled to continue through 1979. The study is designed to provide interested persons with up-to-date information concerning water resources of the area. This information is especially needet by decisionmakers and planners who must make judicious decisions regarding development and use of this land and its natural resources. Results of the study would provide sound background information for rational, wellconsidered decisions among alternative or competing uses of water and related land resources.

This report presents: 1) Objectives of the study; 2) a general description of the study area, including its mineral and water resources; 3) a summary of existing data and knowledge of the water resources of the area; 4) a detailed description of the study plan; and 5) a schedule of reports to be prepared by the study group. This report was prepared so that decisionmakers, planners, and others interested in the subject area may be made aware of the study. Comments regarding the proposed methods of approach are invited from interested persons. Efforts will be made by the U.S. Geological Survey to coordinate this study with the needs of the prospective users, including industries and government agencies. 


\section{Objectives of the Study}

Objectives

The principal objectives of the study are to: 1) Describe the existing water resources and hydrologic relations necessary to determine water supply and predict effects of proposed water development; and 2) design data-collection programs for the evaluation of the effects of water development.

\section{Specific Objectives}

Surface water.--1) Describe distribution and quality of streamflow areally and with time. Special emphasis would be directed toward ephemeral and intermittent streams. 2) Determine the relation of hydrology to other aspects of the environment, including erosion and sedimentation, the biologic community, and land use. 3) Define hydrologic relations necessary for estimating quantity and quality of surface water at sites not routinely gaged or sampled. 4) Develop methods to predict effects of proposed water development.

Ground water.--The present extent and distribution of ground-water withdrawals would be described. The extent and characteristics of the aquifers would be determined in order to predict potential water supplies available for new energy developments. Energy-development sites wiould be monitored to detect potential effects on ground water including:

1. Changes in permeability of confining beds due to mining.

2. Effects of heat from in-situ processing of oil shale on the hydrologic properties of aquifers and on water quality.

3. Changes in water quality resulting from shattering or pulverizing saline rocks in contact with ground waters; also, changes in the solvent action of ground water due to changes in temperature or changes in the content of dissolved gases.

\section{Units of Measurement}

The analyses and compilations in this report were made with English units of measurement. The equivalent metric units are given in the text and illustrations, where appropriate. English units only are shown in tables where, because of space limitations, the dual system of English and metric units would not be practicable. For those readers who may prefer to use metric units rather than English units, conversion factors for terms used in this report are as follows: 
Multiply English units

inches (in)

feet ( $f t$ )

miles (mi)

acres

square miles $\left(\mathrm{mi}^{2}\right)$

gallons (ga1)

gallons per ton (gal/ton)

cubic feet $\left(\mathrm{ft}^{3}\right)$

acre-feet (acre-ft)

barrels (bb1s)

cubic feet per second $\left(\mathrm{ft}^{3} / \mathrm{s}\right) \quad \frac{\text { Flow }}{28.32}$

gallons per minute (gal/min)

million gallons per day (Mgal/d) 43.81

pound (1b)

ton (short)

British therma1 units per pound (BTU/1b)

By

To obtain metric units

$$
28.32
$$

.02832

.04381

$2 \frac{\text { Length }}{25.4}$

.0254

.3048

1. 609

$$
\begin{gathered}
4047 \text { Area } \\
.4047 \\
.4047 \\
.004047 \\
2.590
\end{gathered}
$$

$\frac{\text { Volume }}{3.785}$

3.785

$3.785 \times 10^{-3}$

4.172

28.32

1233

$1.233 \times 10^{-3}$

$1.233 \times 10^{-6}$ 158.8

.06309

.06309

$6.309 \times 10^{-5}$

$453.6 \frac{\text { Mass }}{.6}$

.9072

Heat value
.04381

millimetres (mm)

metres (m)

metres (m)

kilometres $(\mathrm{km})$

square metres $\left(\mathrm{m}^{2}\right)$

hectares (ha)

square hectometre $\left(\mathrm{hm}^{2}\right)$

square kilometres $\left(\mathrm{km}^{2}\right)$

square kilometres $\left(\mathrm{km}^{2}\right)$

litres (1)

cubic decimetres $\left(\mathrm{dr}^{3}\right)$

cubic metres $\left(\mathrm{m}^{3}\right)$

litres per tonne $(1 / t)$

cubic decimetres $\left(d \eta^{3}\right)$

cubic metres $\left(\mathrm{m}^{3}\right)$

cubic metres $\left(\mathrm{m}^{3}\right)$

cubic hectometres $\left(\mathrm{hm}^{3}\right)$

cubic kilometres $\left(\mathrm{km}^{3}\right)$

litres (1)

litres per second ( $1 / \mathrm{s})$

cubic decimetres per second $\left(\mathrm{dm}^{3} / \mathrm{s}\right)$

cubic metres per serond $\left(\mathrm{m}^{3} / \mathrm{s}\right)$

litres per second ( $1 / \mathrm{s})$

cubic decimetres per

second $\left(\mathrm{dm}^{3} / \mathrm{s}\right)$

cubic metres per serond $\left(\mathrm{dm}^{3} / \mathrm{s}\right)$

cubic decimetres per

second $\left(\mathrm{dm}^{3} / \mathrm{s}\right)$

cubic metres per serond $\left(\mathrm{m}^{3} / \mathrm{s}\right)$

grams (gm)

tonne $(t)$

.5556 calorie, gram per gram (cal, $\underline{\mathrm{gm} / \mathrm{gm})}$ 
The location sites of wells, springs, and oil- and gas-test holes, referred to in this report, are designated by a numbering system based on the Federal system of land subdivision. The first number denotes the township, the second number denotes the range, and the third numbar denotes the section. One or more letters follow the section number and denote the location within the section. The section is divided into four quarters of 160 acres $\left(64.8 \mathrm{hm}^{2}\right)$ and lettered $a, b, c$, and $d$ in $a$ counterclockwise direction, beginning in the northeast quarter. Similarly, each quarter may be further divided into quarters of 40 acres $\left(16.2 \mathrm{hm}^{2}\right)$ and again into 10-acre $\left(4.05 \mathrm{hm}^{2}\right)$ tracts and lettered as before. The first letter following the section number denotes the quarter section; the second letter, if shown, denotes the quarter-quarter section; and the third letter denotes the quarter-quarter-quarter section, or 10-acre $\left(4.05 \mathrm{hm}^{2}\right)$ tract. For example, in the following illustration,

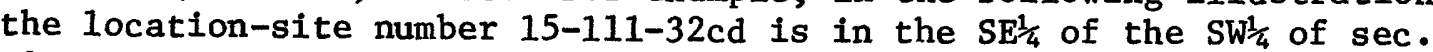
32, T. $15 \mathrm{~N} .$, R. $111 \mathrm{~W}$. :

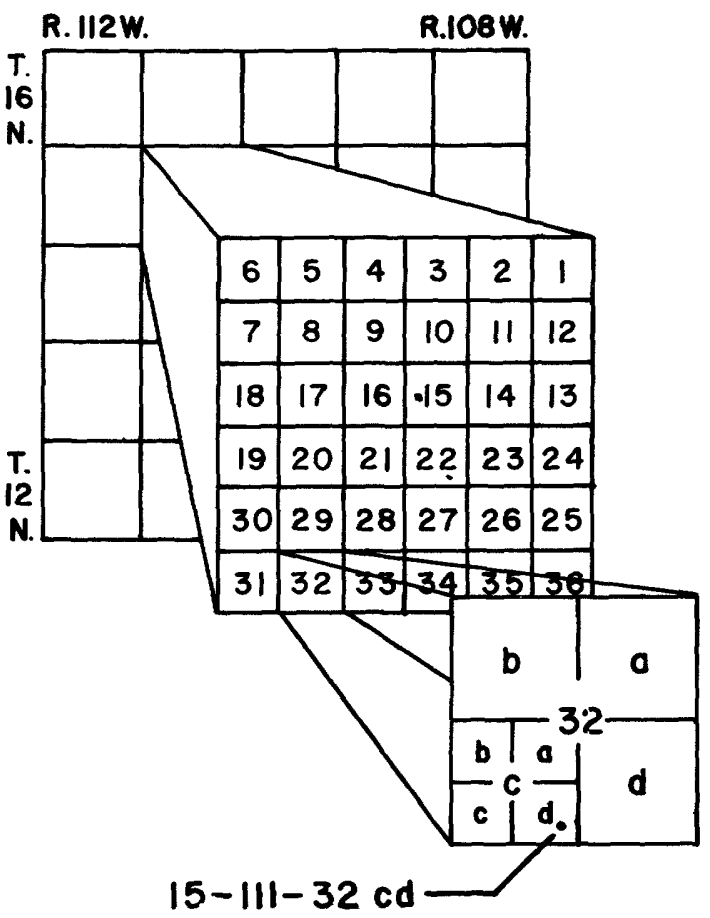

Each streamflow and water-quality station referred to in this report has a station number. The complete 8-digit number, such as 09188500, includes the part number "09" and a 6-digit station number. The first two digits designate the part number, which refers to the major drainage basin involved. The last six digits refer to individual station location with increasing numbers referring to locations progressively farther downstream. 


\section{Location}

The study area includes approximately $21,020 \mathrm{mi}^{2}\left(54,440 \mathrm{~km}^{2}\right)$ in southwestern Wyoming, bordering on the states of Utah and Colorado. Its location with reference to Wyoming is shown in figure 1 . The study area is that part of southwestern Wyoming drained by the Green River ard its tributaries, including the Little Snake River and other tributaries that join the Green River downstream from the State 1ine, and the Great:

Divide Basin. The Green River Basin is about $17,100 \mathrm{mi}^{2}\left(44,290 \mathrm{~lm} \mathrm{~m}^{2}\right)$, and the Great Divide Basin is about $3,920 \mathrm{mi}^{2}\left(10,150 \mathrm{~km}^{2}\right)$.

The Great Divide Basin is topographically closed, so all surface drainage is internal. The Great Divide Basin is technically considered to be part of the North Platte River system; however, it is incluced in this study because the Green River and Great Divide Basins have similar geologic features, and both have large deposits of oil shale and coal.

\section{Physiography}

The study area is a high desert plateau flanked by higher morntain ranges. The Wind River Range to the northeast, the Gros Ventre Range to the north, the Wyoming Range to the west, the Uinta Mountains to the south, and the Sierra Madre to the southeast border the interior flains. Elevations range from $6,050 \mathrm{ft}(1,840 \mathrm{~m})$ in the Green River drainage near the State line to $13,785 \mathrm{ft}(4,202 \mathrm{~m})$ at Gannett Peak in the Wind River Range.

More than 1,000 glacial lakes are located in headwater areas of streams that originate along the west slope of the Wind River Range. Numerous perennial streams originate in the mountain ranges.

The interior plains of the Green River Basin are characterized by shallow river valleys and scattered buttes rising from the basin floor. Ephemeral and intermittent streams originate in this area of treeless plains, mesas, and picturesque badlands. Active sand dunes are present in the central part of the basin.

The Great Divide Basin is a relatively shallow depression with isolated buttes, pan-like depressions, and sparse vegetation. The. Continental Divide is the hydrographic boundary separating the Great Divide and Green River Basins, but it is barely perceptible as a surface feature along much of its length. 


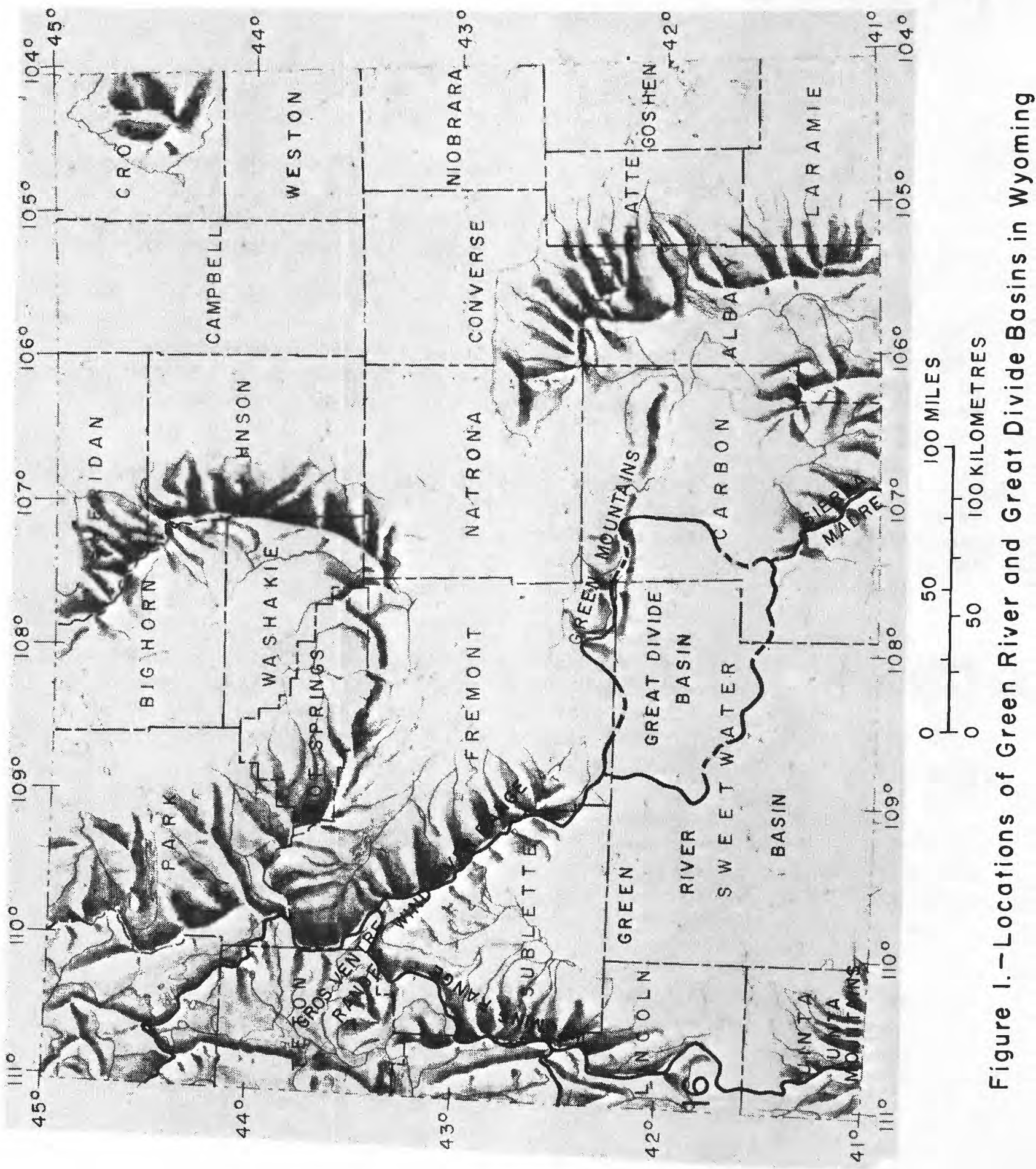




\section{$\underline{\text { Geology }}$}

The study area contains four major structural units: The Green River, Washakie, and Great Divide Basins; and the Rock Springs Uplift. Their geographic locations are shown in figure 2.

The Green River structural basin is a large (approximately $600 \mathrm{mi}^{2}$ or $1,600 \mathrm{~km}^{2}$ ) synclinal basin with a north trending axis. The beds of Tertiary rocks in most of the basin are nearly flat lying, with dips genera11y less than $1^{\circ}$. In a narrow margin around the perimeter of the basin dips are steeper, but less than $15^{\circ}$ in most areas. The southern margin is an exception, where dips up to $35^{\circ}$ occur and some beds are overturned as a result of a large thrust fault. The beds about $200 \mathrm{ft}(60 \mathrm{~m})$ north of this fault are dipping less than $15^{\circ}$ (Bradley, 1964, p. A-9, A-10).

The Washakie Basin is an almost circular synclinal basin also with a north trending axis and very low-dipping beds. Dips of Tertiary rocks range from nearly $0^{\circ}$ in most of the basin to $15^{\circ}$ along the margins. In the southern part of the basin, approximately from Shell Creek east to Baggs, Wyo., there are gentle folds and many northwest trending faults (Bradley, 1964, p. A-10).

The Great Divide Basin is an asymmetrical synclinal basin. The axis of the basin trends northwest, and rocks have an average dip of about $3^{\circ}$ on the southwest $1 \mathrm{imb}$ and more than $20^{\circ}$ on the northeast $1 \mathrm{imb}$ (Welder and McGreevy, 1966, p. 4). The northern end of the basin is bounded by the Wind River Range and the Green Mountains and is highly faulted.

The Rock Springs Uplift separates the Green River and Washakie Basins. It is an asymmetrical, doubly plunging anticline. Cretaceous rocks dip $12^{\circ}$ on the west flank and $5^{\circ}$ or $6^{\circ}$ on the east (Bradley, 1964, p. A-10). The axis of the uplift is north trending. The center of the uplift has been eroded, and rocks of the Mesaverde Group and the Baxter shale of Cretaceous age are exposed.

Extensive work has been done by several researchers on the geology of the Green River structural basin. Most of this work has been in the study of rocks of Late Cretaceous and Tertiary ages. Approximately 80 percent of the rocks exposed at the surface are post-Cretaceous in age. Depths to the top of rocks of Early Cretaceous age generally exceed $8,000 \mathrm{ft}(2,400 \mathrm{~m})$ except near the Rock Springs Up1ift.

A generalized column of the formations, groups, and some members in the study area is shown in table 1. 


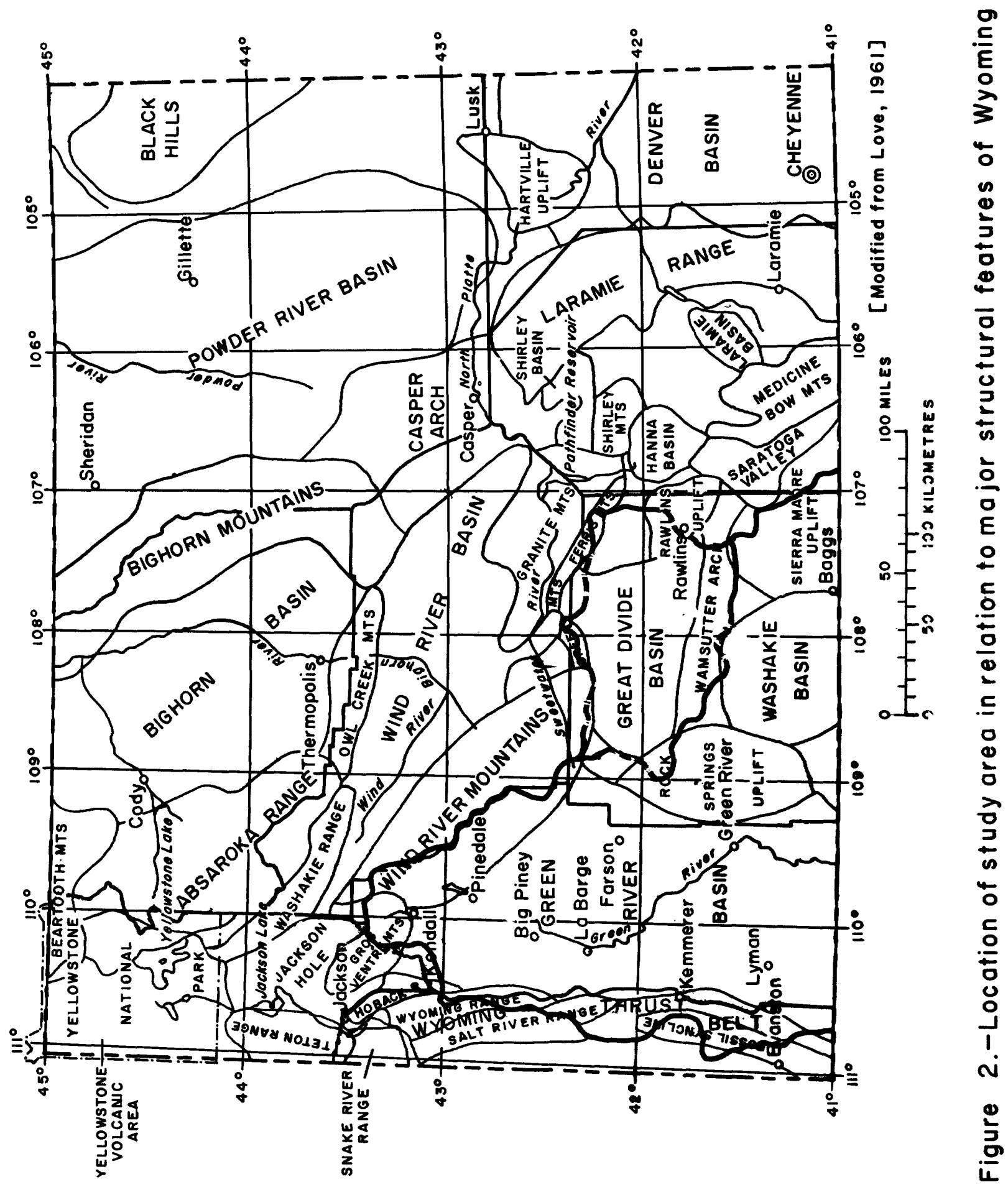




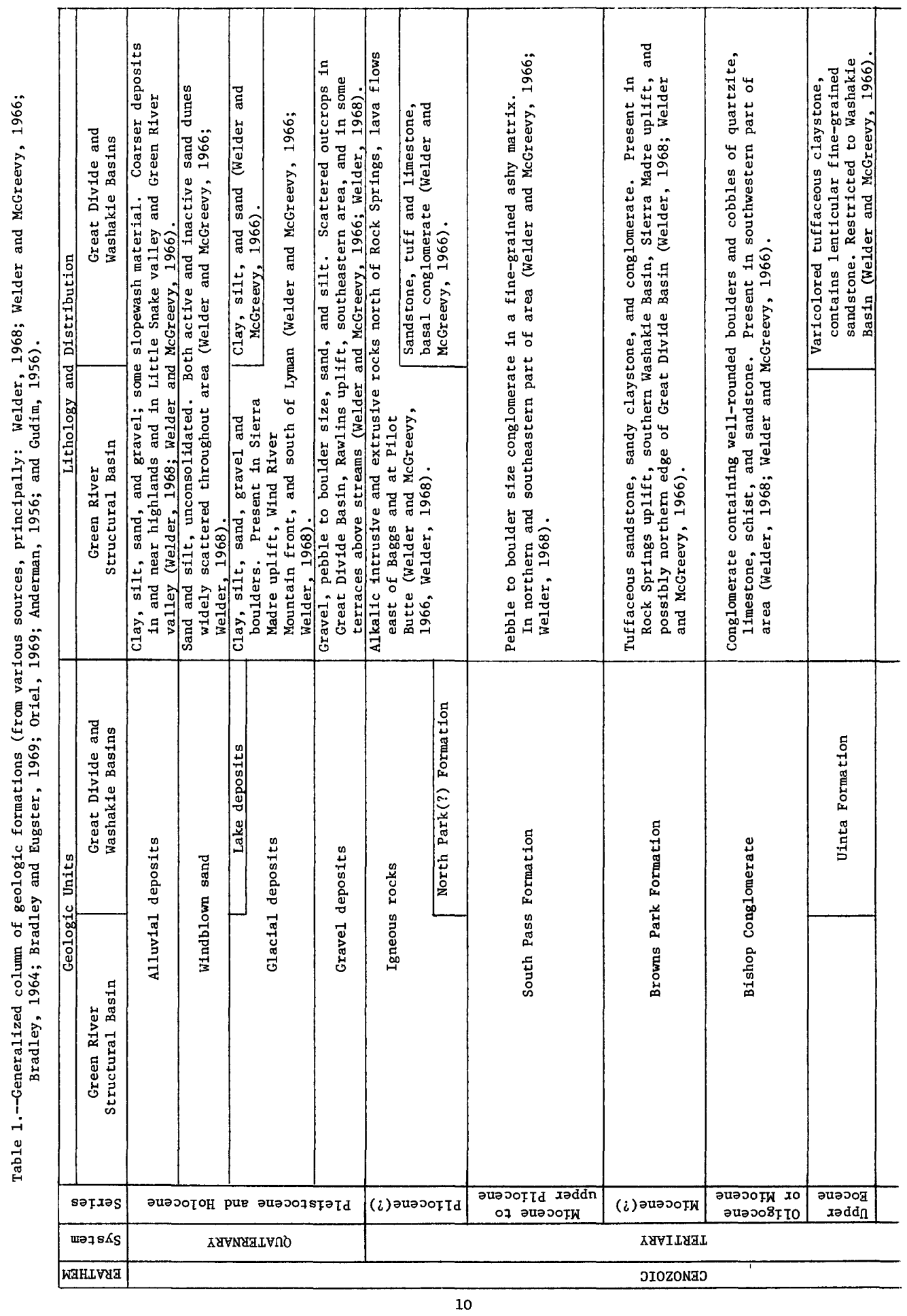




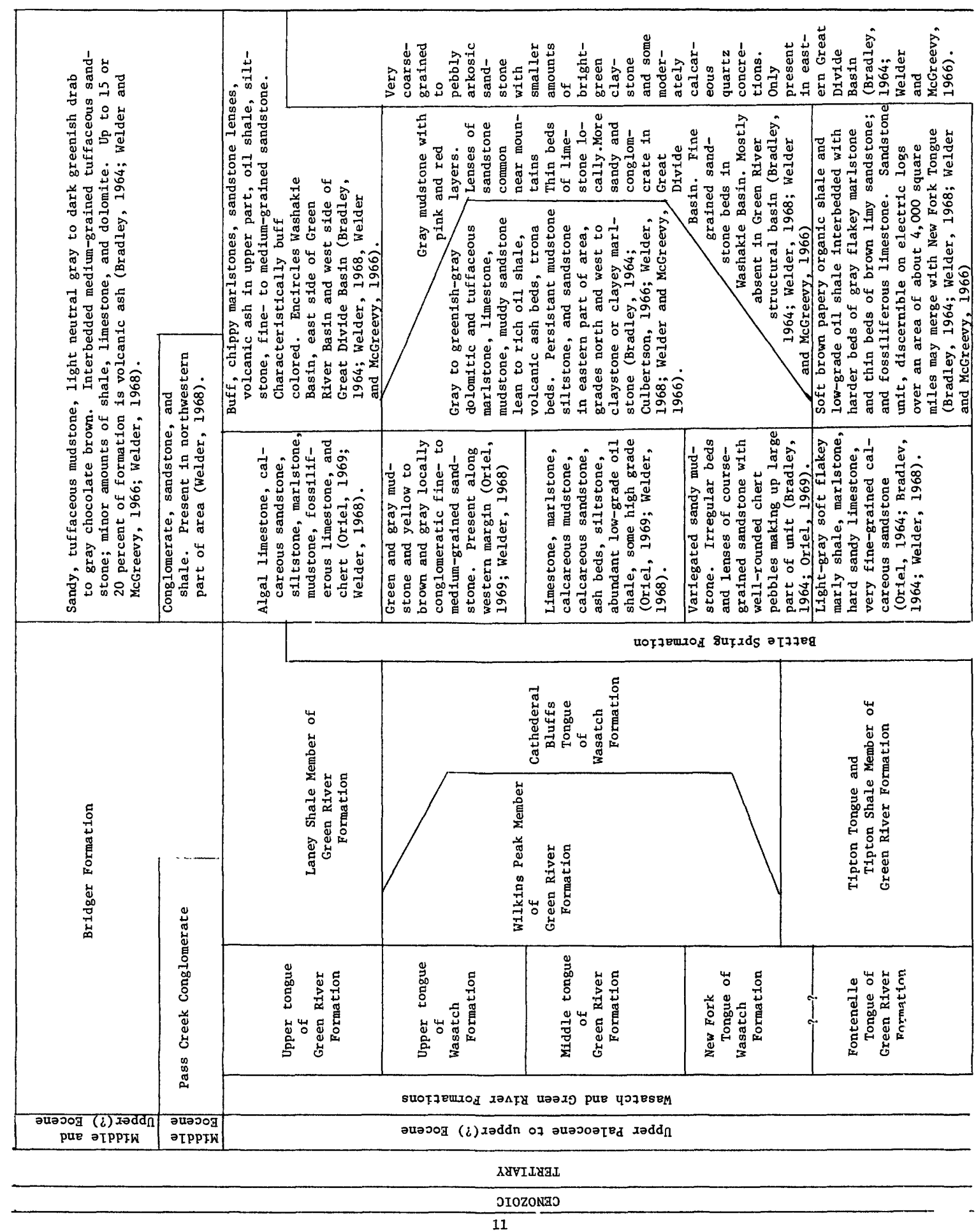




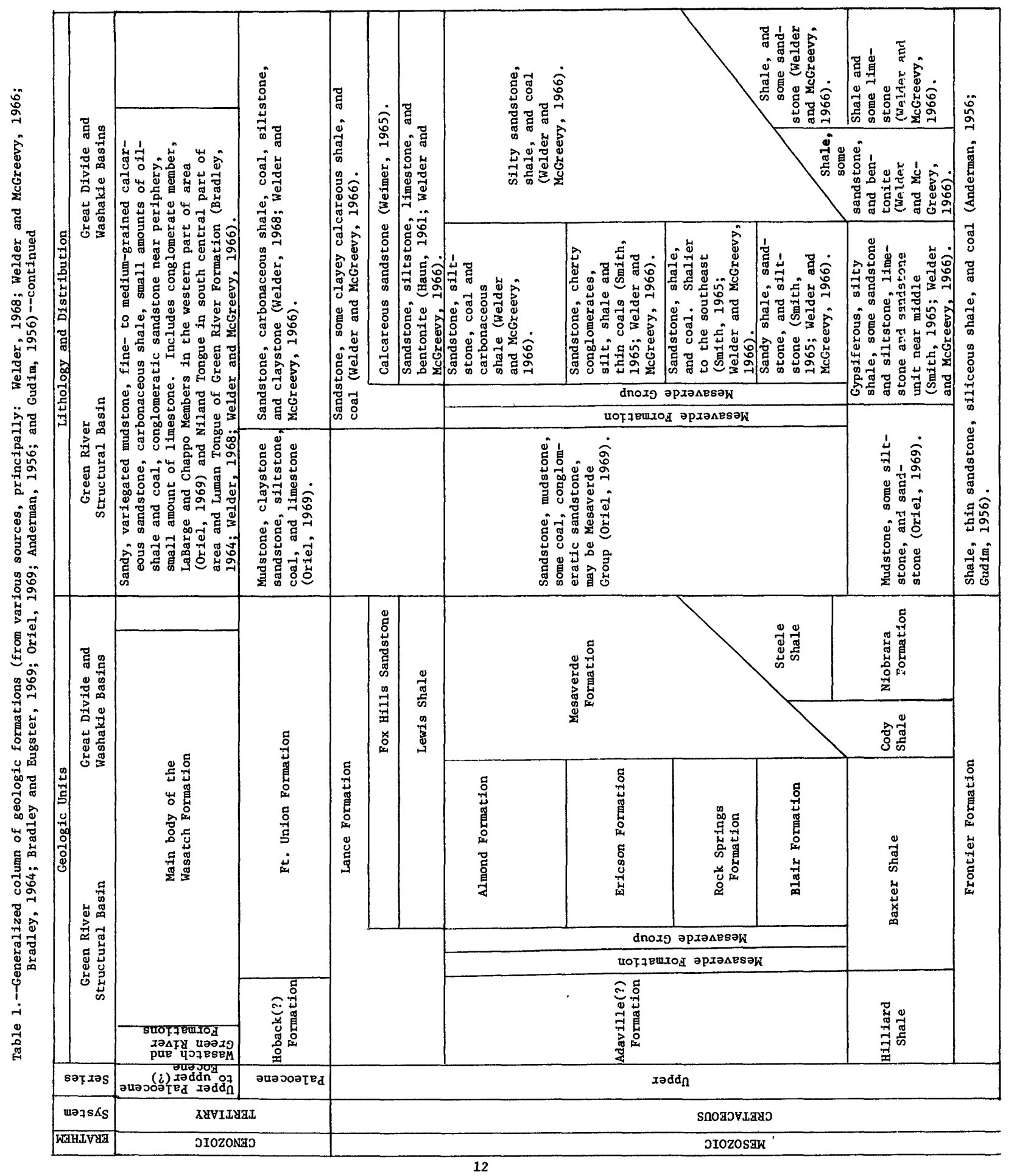




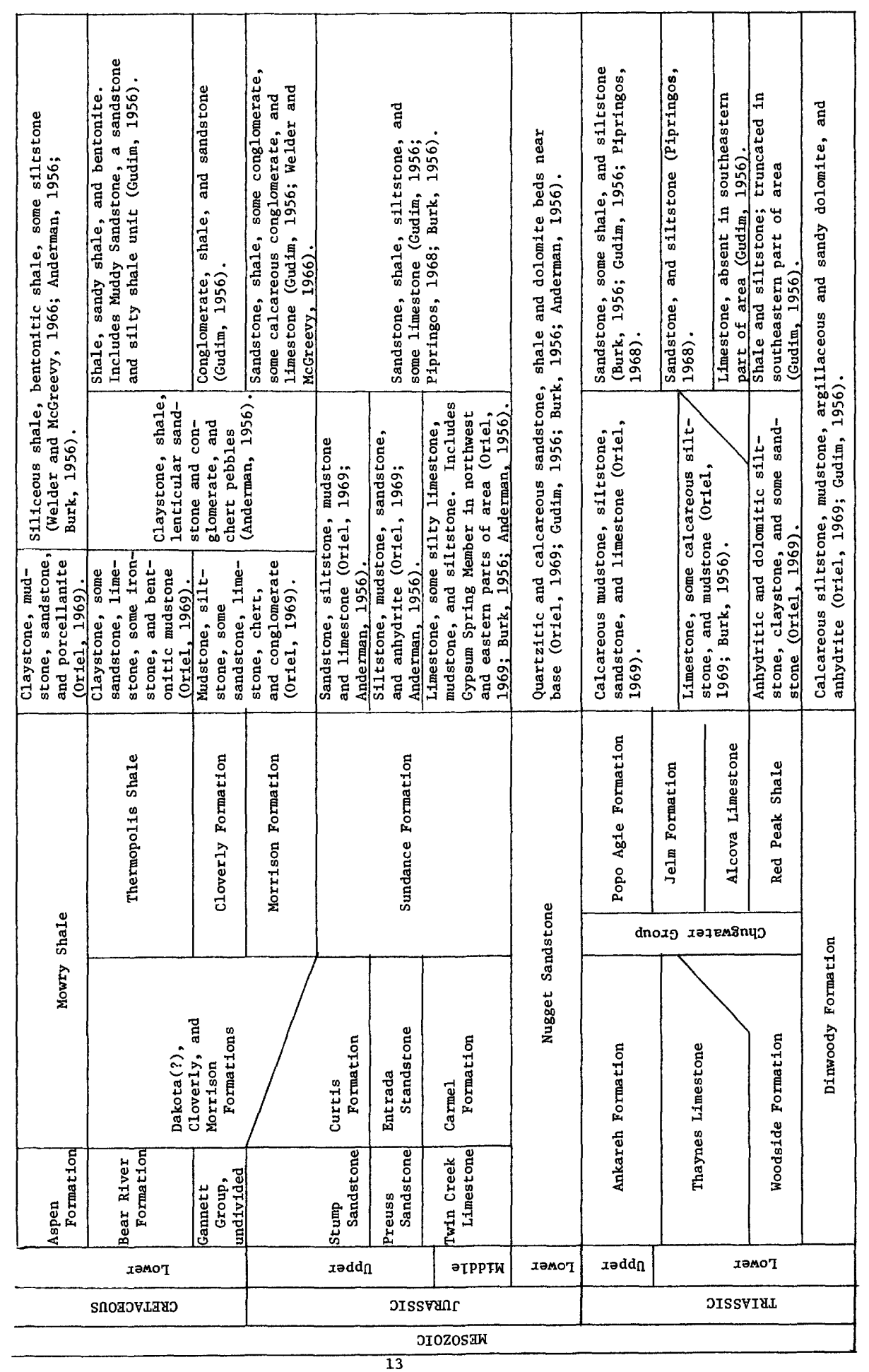




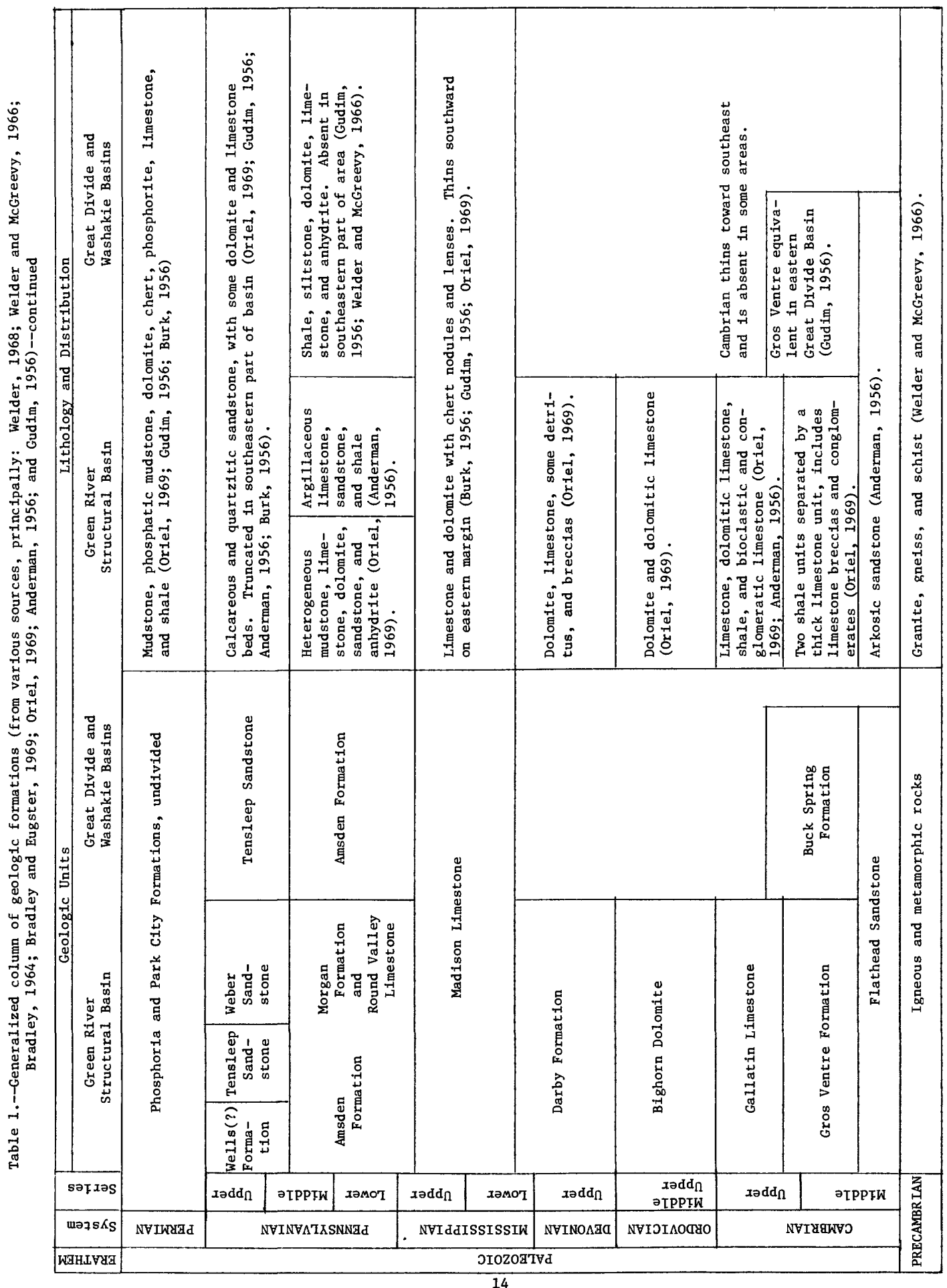


Most of the exposed and near surface formations are of Tertiary age, and those of particular importance are the Wasatch, Green Rirer, and Bridger Formations. The intertonguing relation of these three formations is shown in figure 3.

\section{Climate}

The climate within the study area varies widely according to location, elevation, and topography. The mountainous areas annually receive as much as 40 in $(1,000 \mathrm{~mm})$ of precipitation, while the interior plains area receives as little as 6 in $(150 \mathrm{~mm})$. The high elevation and northerly latitude of the area results in relatively low average temperatures and short growing seasons.

The main source of precipitation for the basins is maritime air masses from the Pacific Ocean. Canadian arctic air masses occasionally move into the area, but are usually blocked by the Wind River Range. The variation of mean annual precipitation in the basins is shown in figure 4 .

The variation of precipitation throughout the year is shown in table 2, which shows monthly averages for representative weather stations.

Variations of temperature at different sites throughout the year are shown in table 3, which shows monthly and annual mean temperatures. The relatively high elevation along with the varying warm and cold air masses that move through the area cause large annual and daily temperature ranges. The maximum recorded summer temperature is $107^{\circ} \mathrm{F}\left(41.7^{\circ} \mathrm{C}\right)$, at the Green River Aviation station. The coldest recorded winter temperature is $-55^{\circ} \mathrm{F}\left(-48.3^{\circ} \mathrm{C}\right)$, at Farson.

The average growing season of the basins is shown in figure 5. The growing season for the main crops of the study area, grass ant alfalfa, is between the last killing frost in the spring and the first killing frost in the fall. A killing frost for these crops is considered to occur when the minimum temperature dips to $28^{\circ} \mathrm{F}\left(-2.2^{\circ} \mathrm{C}\right)$ or lower.

Winds are relatively strong, especially in the plains areas. Wind velocity averages about $15 \mathrm{mi} / \mathrm{hr}(24 \mathrm{~km} / \mathrm{hr})$ during winter and spring, and about $8 \mathrm{mi} / \mathrm{hr}(13 \mathrm{~km} / \mathrm{hr})$ during summer. Strong winds of 30 to $40 \mathrm{mi} / \mathrm{hr}$ (48 to $64 \mathrm{~km} / \mathrm{hr}$ ) with stronger gusts sometimes prevail for several days. Wind direction is predominantly from the west. 


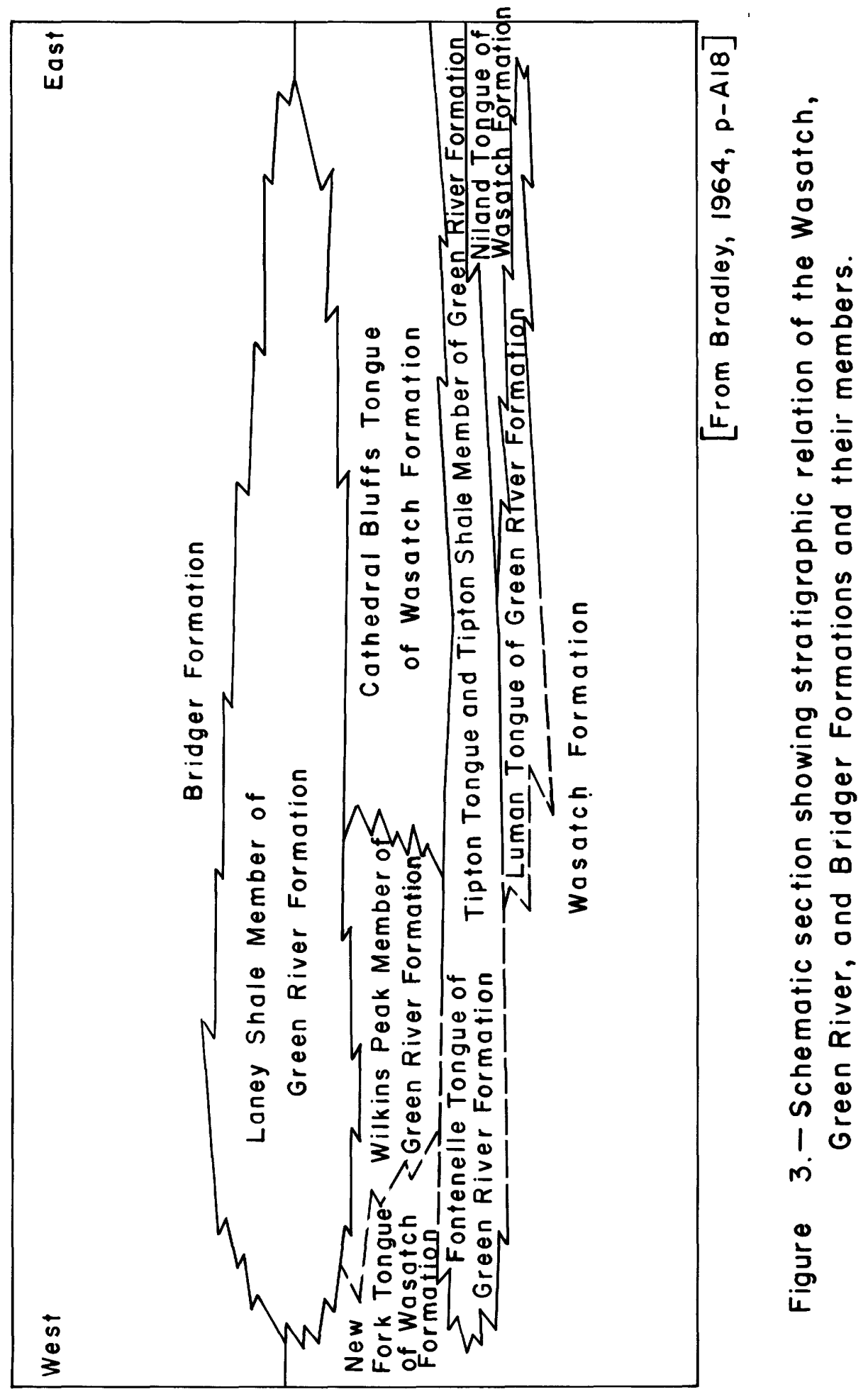




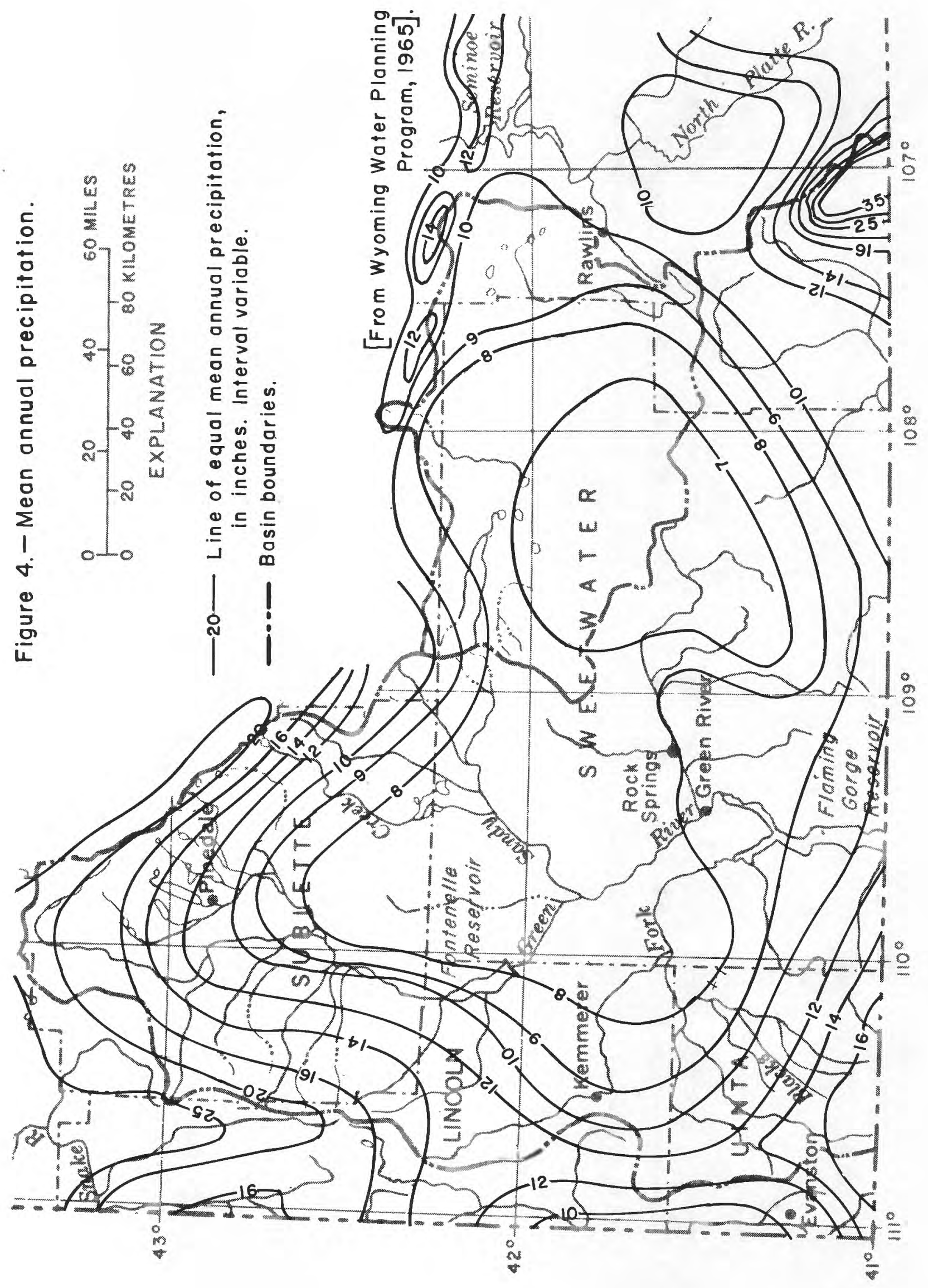




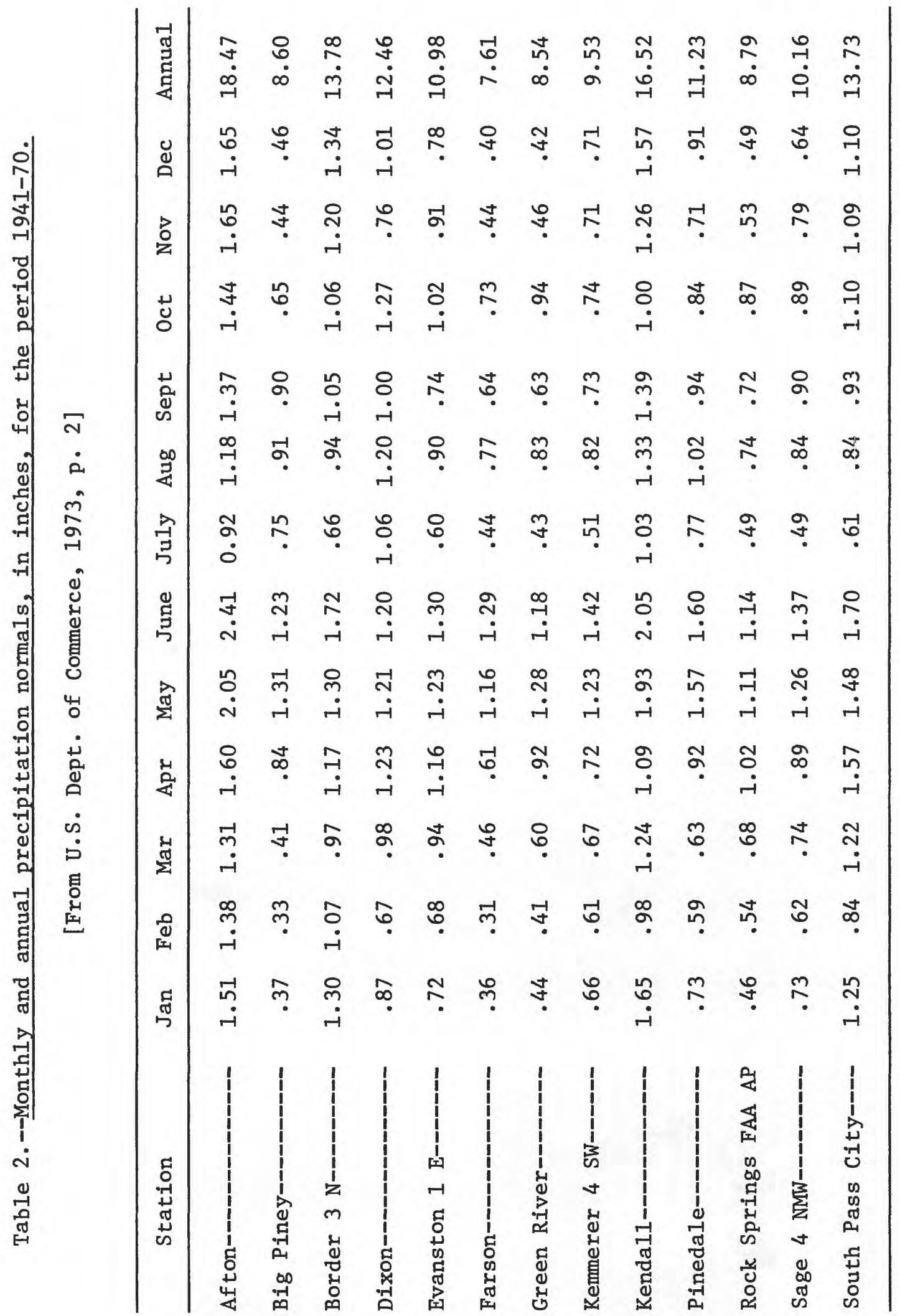




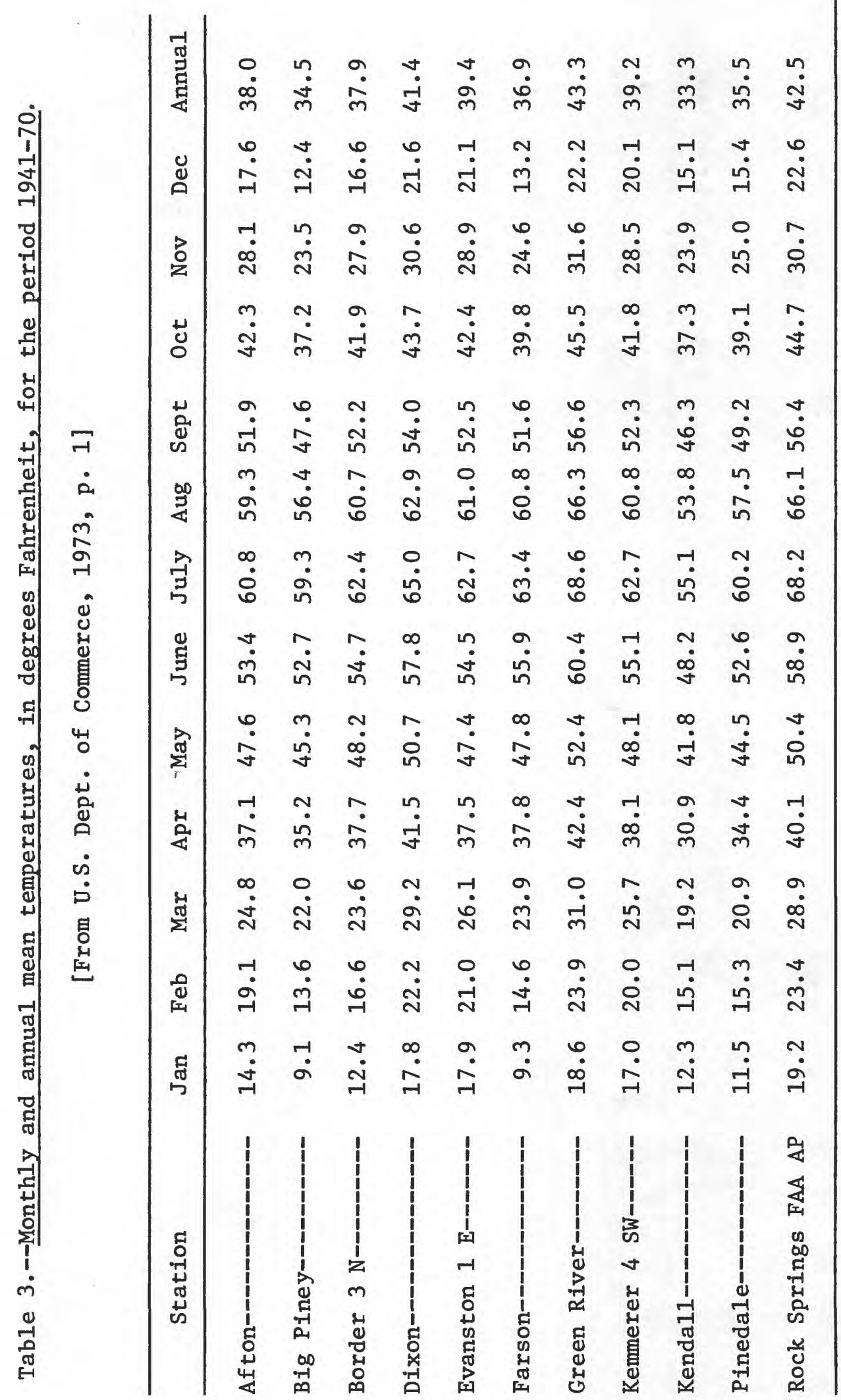




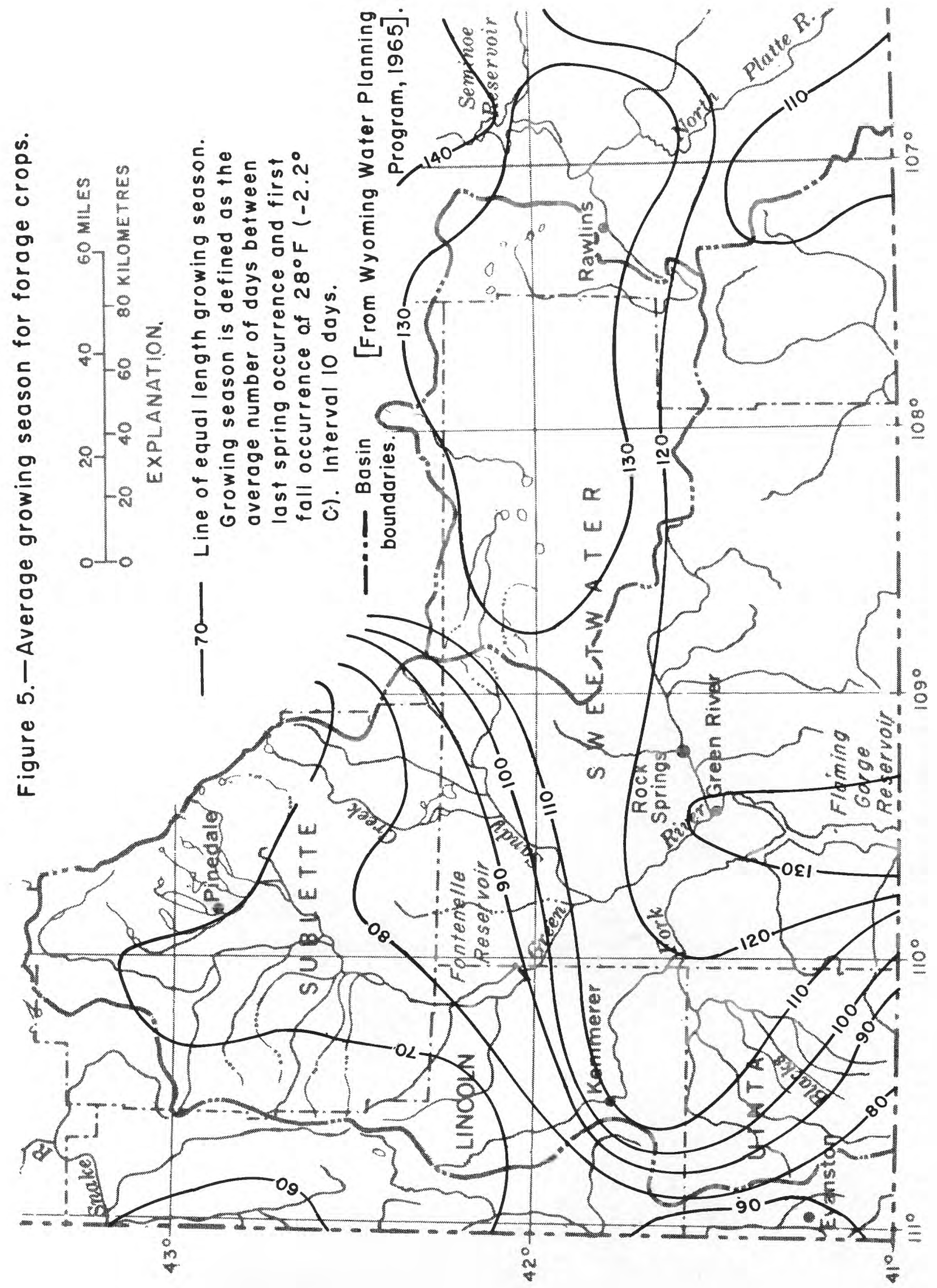




\section{Vegetation}

Figure 6 is a map showing general vegetal cover types in the study area. Vegetal cover types indicate regions having similar plants, soils, and climates.

\section{Land Use}

Population and Economic Base

According to the Bureau of Census (1970), approximately 37,000 people lived in the Green River Basin during 1970 with population concentrated in the cities of Rock Springs, Green River, and Kemmerer. However, significant commercial development with accompanying influx of people has occurred since 1970. An estimated increase of 11,000 people has occurred (S. Young, Sweetwater County Planner, written commun., 1975) in the cities of Rock Springs and Green River since 1970. Kemmerer and other areas have experienced a more limited expansion.

Mining, oil and gas production, power plants, and supporting industries and services account for most of the recent economic growth and population influx. Agriculture, timbering, and tourism are also important industries. Figure 7 shows locations of timber Industries in the study area. Locations of mineral resources are shown later in the report.

\section{Commerce}

Portions of all raw materials are exported to other states by rail, pipeline, and road. Figure 8 shows the major transportation systems. Some products such as timber, beef, oil, gas, and coal are used in the Green River Basin and Statewide. Almost all finished or manufactured products available in the study area are imported from other parts of the State, other states, and other countrles.

\section{Recreation}

The Green River Basin provides numerous and diverse recreational opportunities. These include the rugged mountains on the northern $\mathrm{rIm}$ of the basin with their pristine streams and alpine lakes, the lower desert area that provides a habitat for antelope and mule deer, many miles of fishing streams, Fontenelle Reservoir, and the Flaming Gorge National Recreation Area. Hunting, flshing, boating, camping, hiking, skiing, and snowmobiling are some of the popular activities in the area. 


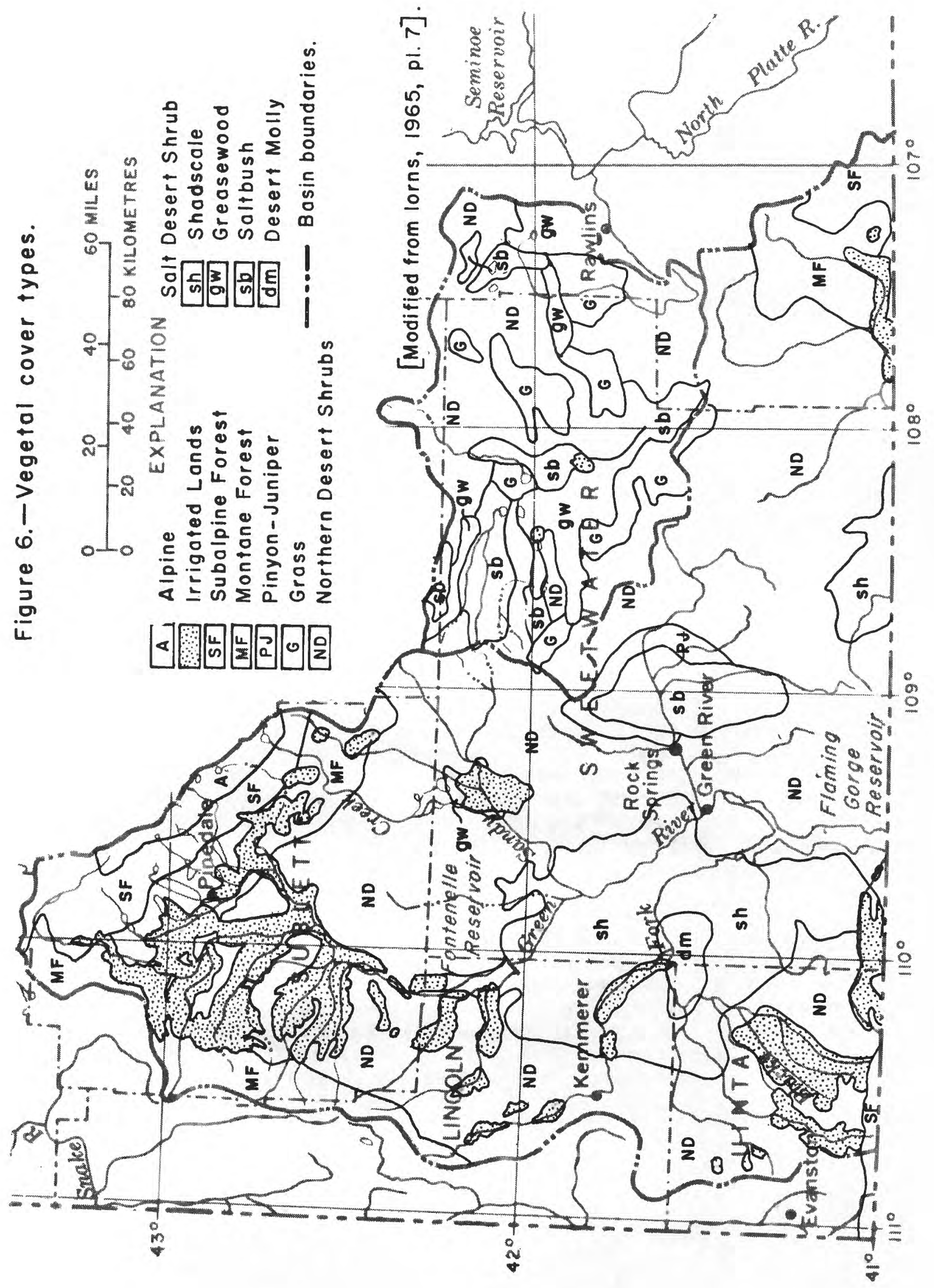




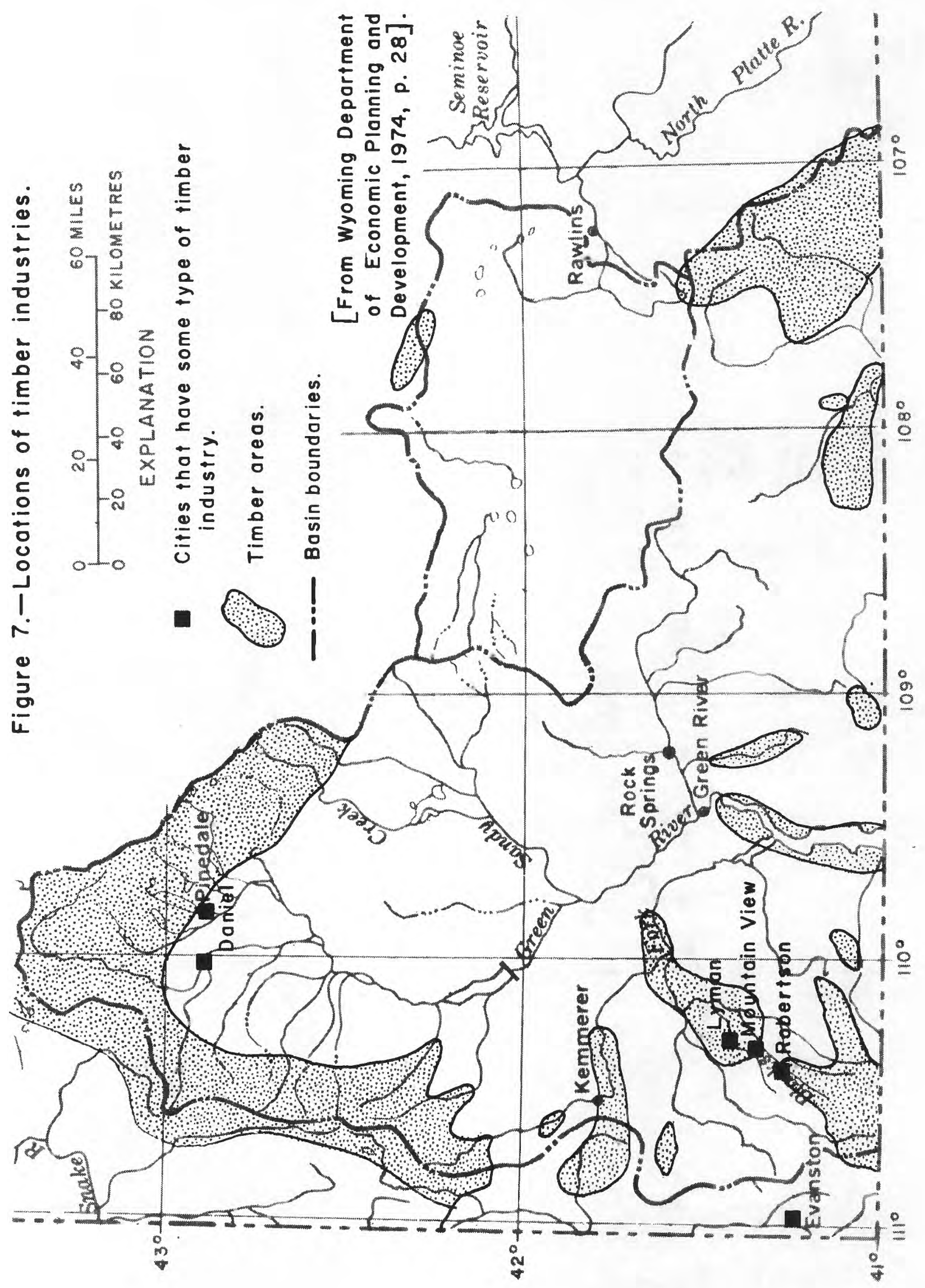




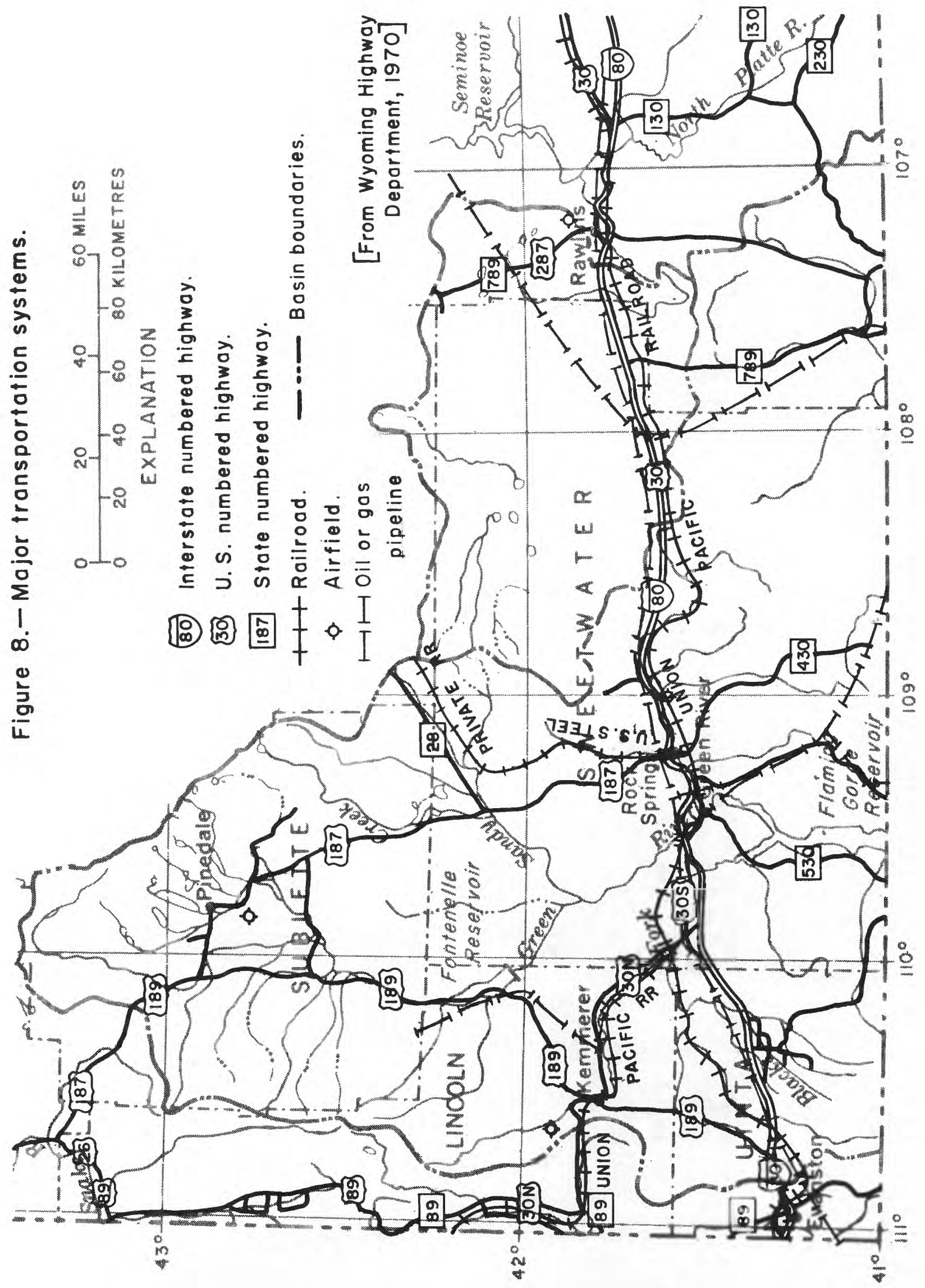




\section{Agriculture}

There are about 4,000 acres $\left(16 \mathrm{~km}^{2}\right)$ of dry cropland and more than 300,000 acres $\left(1,200 \mathrm{~km}^{2}\right)$ of irrigated 1 and in the Green River and Great Divide Basins. Because of a combination of factors including a short growing season and the low water-holding capacity of the shallow soils, nearly two-thirds of the irrigated land is used for pasture and production of native hay. Agriculture is based on the production of livestock, and most of the harvested hay and limited amounts of grain are used 1oca11y.

Irrigated lands are located mostly along stream channels and along the terraces bordering the channels. Soil textures vary from sandy loam on the terraces to clay in some reaches of the river bottoms and are normally underlain with several feet of sand and gravel. Irrigated lands are shown in figure 6.

\section{Energy Minera1 Resources}

Energy mineral resources include oil, natural gas, coal, uranium, and oil shale. Background information concerning reserves and production in this report are from the Wyoming Geological Survey, office of the Wyoming State Engineer, U.S. Bureau of Mines, and the U.S. Geological Survey.

Oil and Gas.--The oil and gas industry in the study area contributes significantly to United States production levels. Figure 9 shows oil and natural gas fields in the study area. The study area currently contributes about 9.1 percent of Wyoming crude-oil production and about 57 percent of Wyoming natural-gas production (Wyoming Water Planning Program, 1970, p. 82).

Coal.--Current estimates place recoverable reserves of coal in the study area at more than 19 billion tons ( 17 billion tonnes). Estimated recoverable, strippable subbituminous coal resources as of January 1 , 1972 were over 900 million tons ( 800 million tonnes) (Glass, 1973, p. 118). The coal mining areas are shown in figure 10.

Coal is currently being mined from three strip mines and two underground mines. Several new strip mines are in the planning stage. (See fig. 10.) Two coal-fired power plants and two coke plants are currently in operation.

In addition to expanded mine facilities, more power, syntheticcoke, synthetic-1iquid and gas-fuel plants may be built in the future. The large individual deposits of subbituminous coal are desirable for processes that convert coal to gaseous and liquid fuels. It is expected that the synthetic-coke industry will expand its facilities as demand increases. 


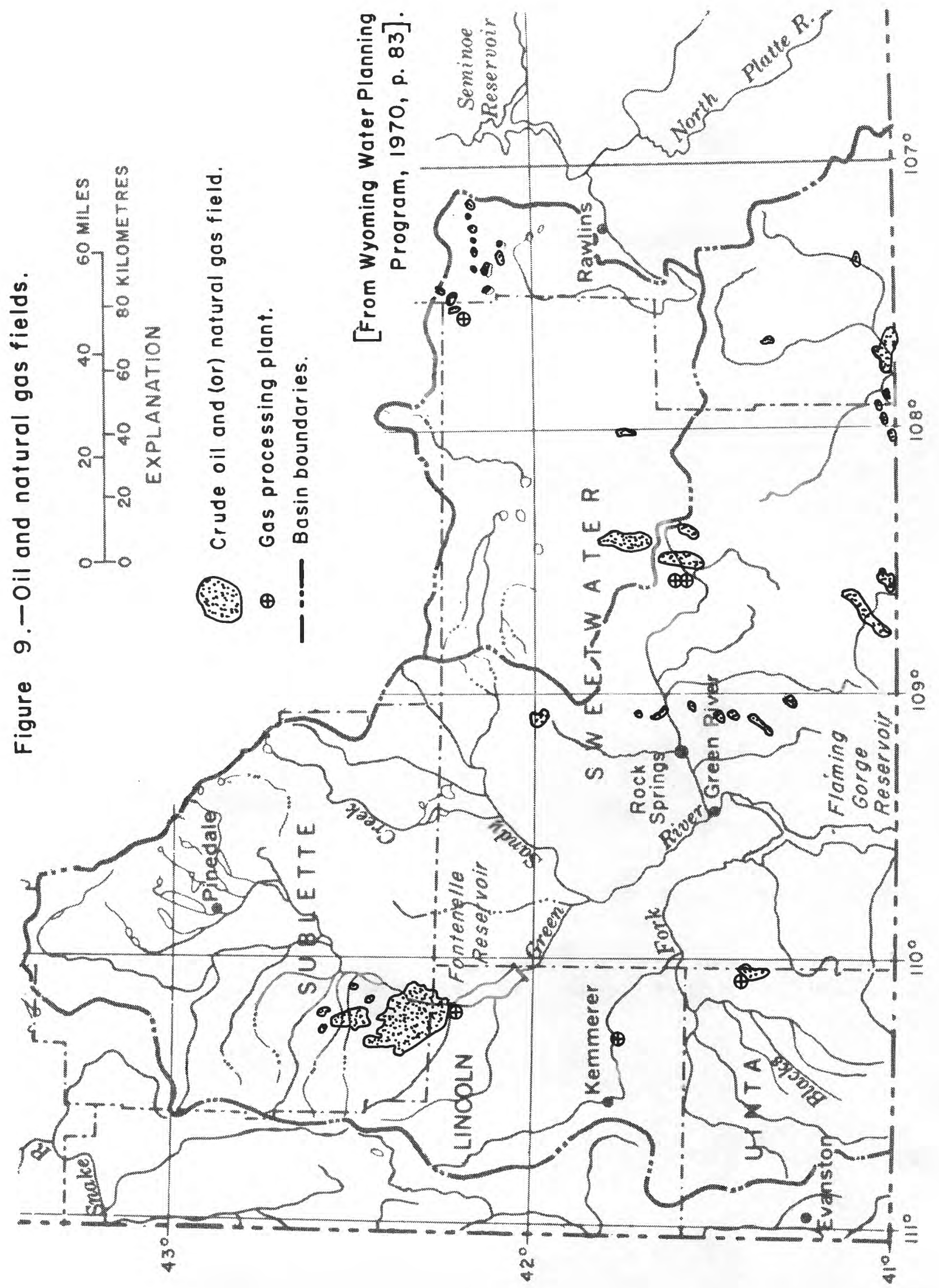




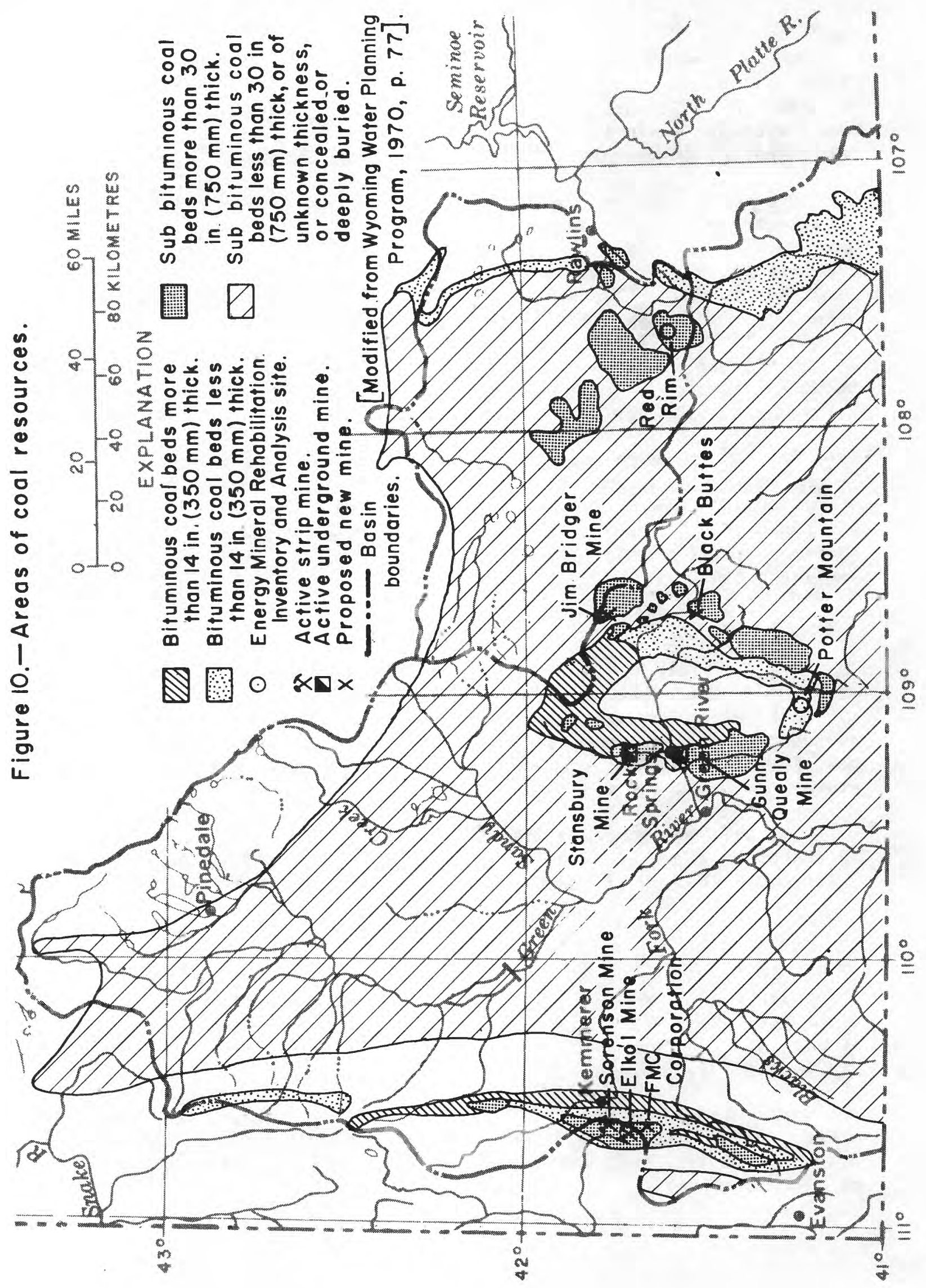


Uranium.--Two uranium mines are currently being operated in the Great Divide structural basin. Figure 11 shows locations of the mines and areas of major uranium exploration. Known deposits of uranium in the study area are generally low grade, but have economic potential because their shallow depths are suitable for surface mining.

Oil shale.--Recent demands for National independence in energy have accelerated the development of technology that would make it economically practical to use oil shale as a source of fuel. The principal oil-shale deposits are in the Green River Formation of Tertiary age in Colorado, Utah, and Wyoming. There are about $25,000 \mathrm{mi}^{2}\left(65,000 \mathrm{~km}^{2}\right)$ of land with underlying oil-shale deposits in Wyoming, Utah, and Colorado (U.S. Dept. of Int., 1973, v. I, p. I-2). About $17,000 \mathrm{mi}^{2}\left(44,000 \mathrm{~km}^{2}\right)$ are underlain by deposits of potential commercial value. There are about 30 billion barrels (over 1.3 trillion gal or 4.8 trillion 1 ) of shale oil in rich oil-shale deposits in Wyoming.

West of the Rock Springs Uplift, the richest oil-shale deposits are in the Wilkins Peak and Tipton Shale Members; in the Washakie Basin, the richest are in the Tipton Shale and Laney Shale Members (Surdam and Wolfbauer, 1973, p. 207). The general locations of surface exposures of three oil-shale bearing members of the Green River Formation are shown in figure 12.

\section{Non-Energy Minerals}

The main non-energy mineral currently mined in the Green River Basin is trona. Trona is a basic material for production of soda ash, sodium bicarbonate, sal soda, and sodium tripolyphosphate. These products are used in many industries such as pulp and paper, glass, textiles, and foods. Soda ash $\left(\mathrm{Na}_{2} \mathrm{CO}_{3}\right)$ is the primary product of the trona in Wyoming and most of this is used outside the State.

The only commercial deposits of trona are in the Green River Formation as shown in figure 13. The deposits are well described by Culbertson (1966, p. 158-164) and by Bradley and Eugster (1969).

\section{Land Ownership}

Figure 14 shows the approximate distribution of land ownership within the study area. Table 4 lists details concerning land ownership as determined by the Upper Colorado Region Comprehensive Framework Study (1971, App. VI, p. 15).

Sixty-eight percent of the land is Federally owned, 7 percent State owned, and 25 percent is in private, municipal, or county ownership. The Union Pacific Railroad owns a "checkerboard" of every other section of land in a strip $20 \mathrm{mi}(32 \mathrm{~km})$ wide on each side of the railroad. 


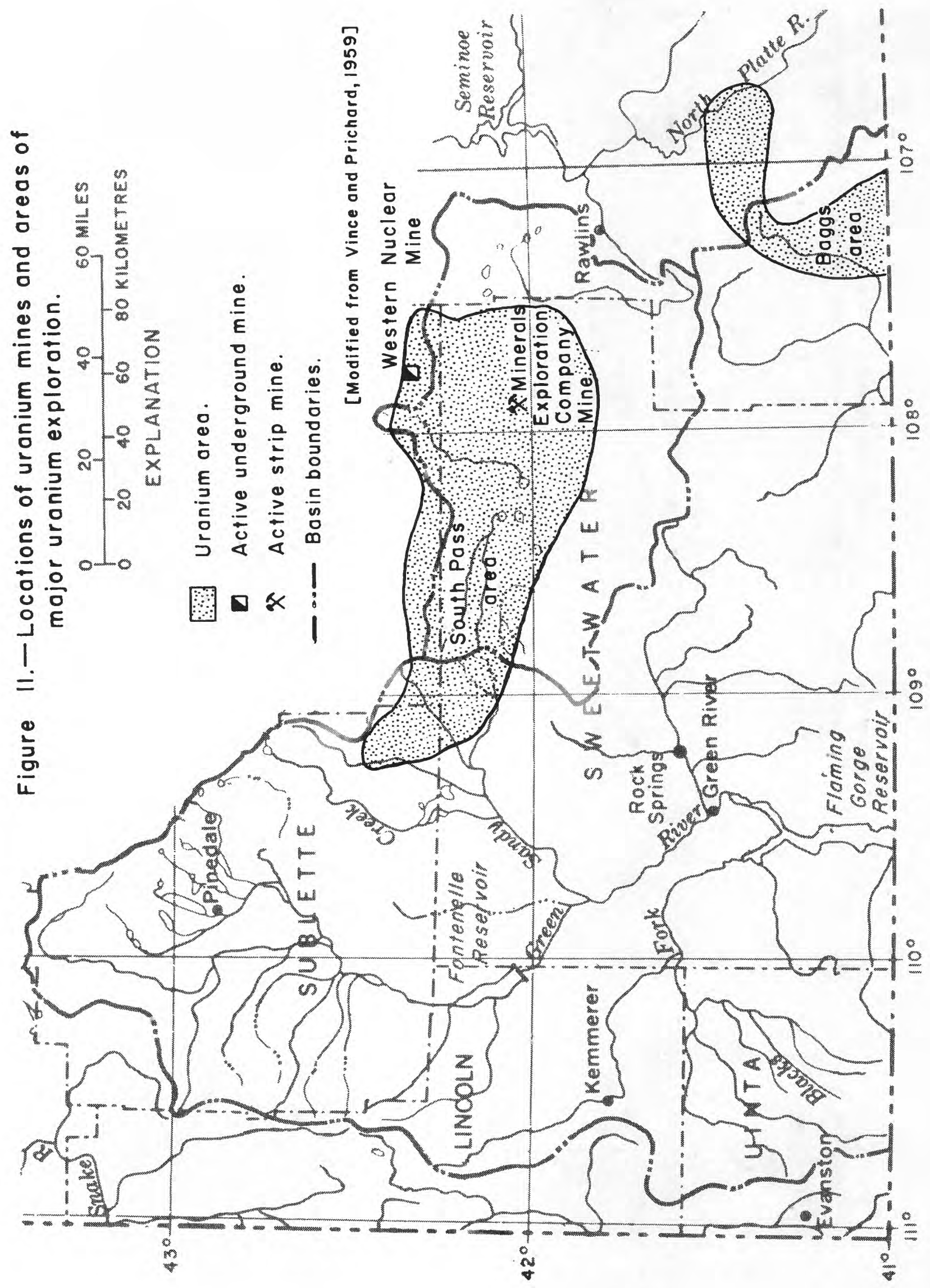




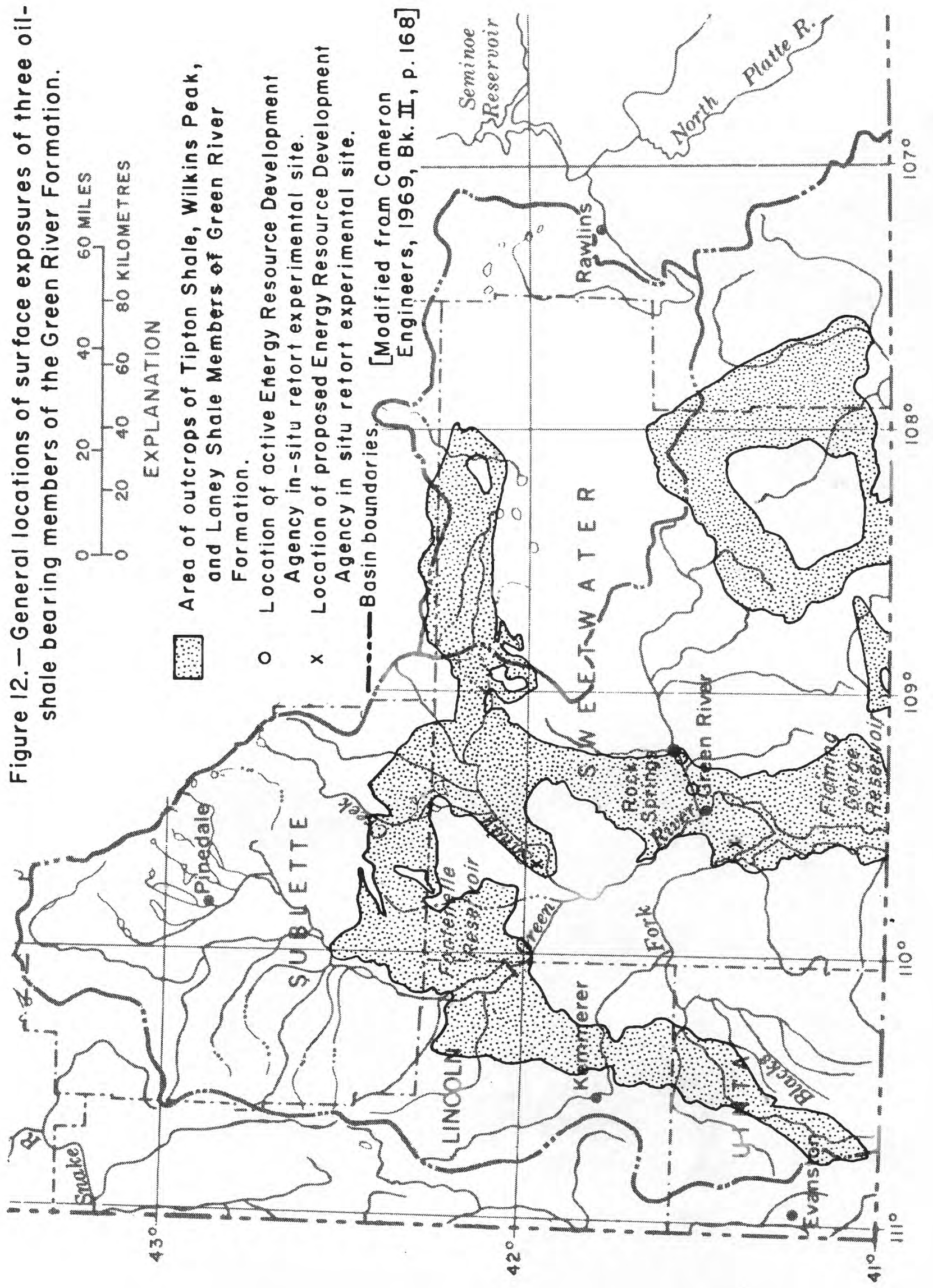




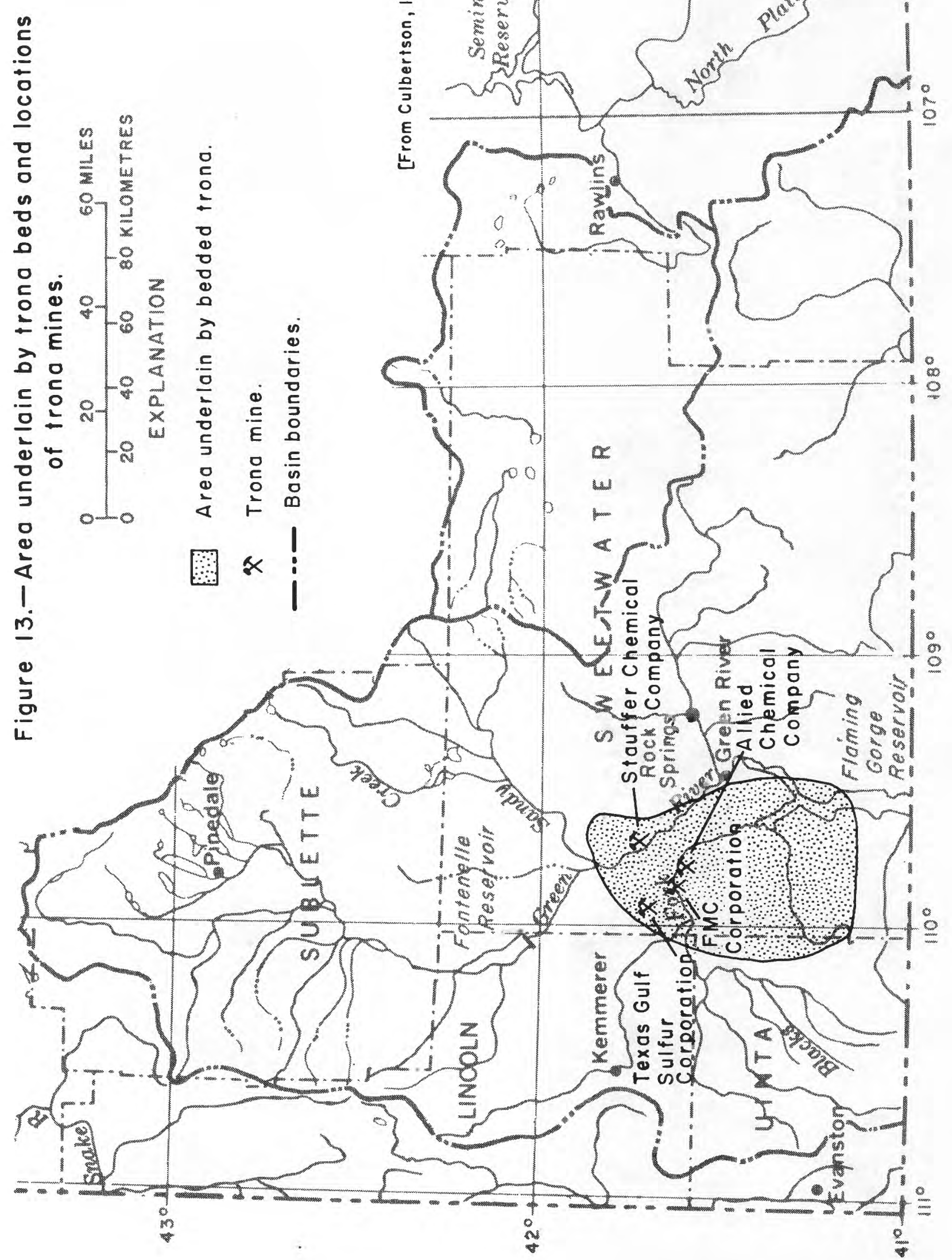




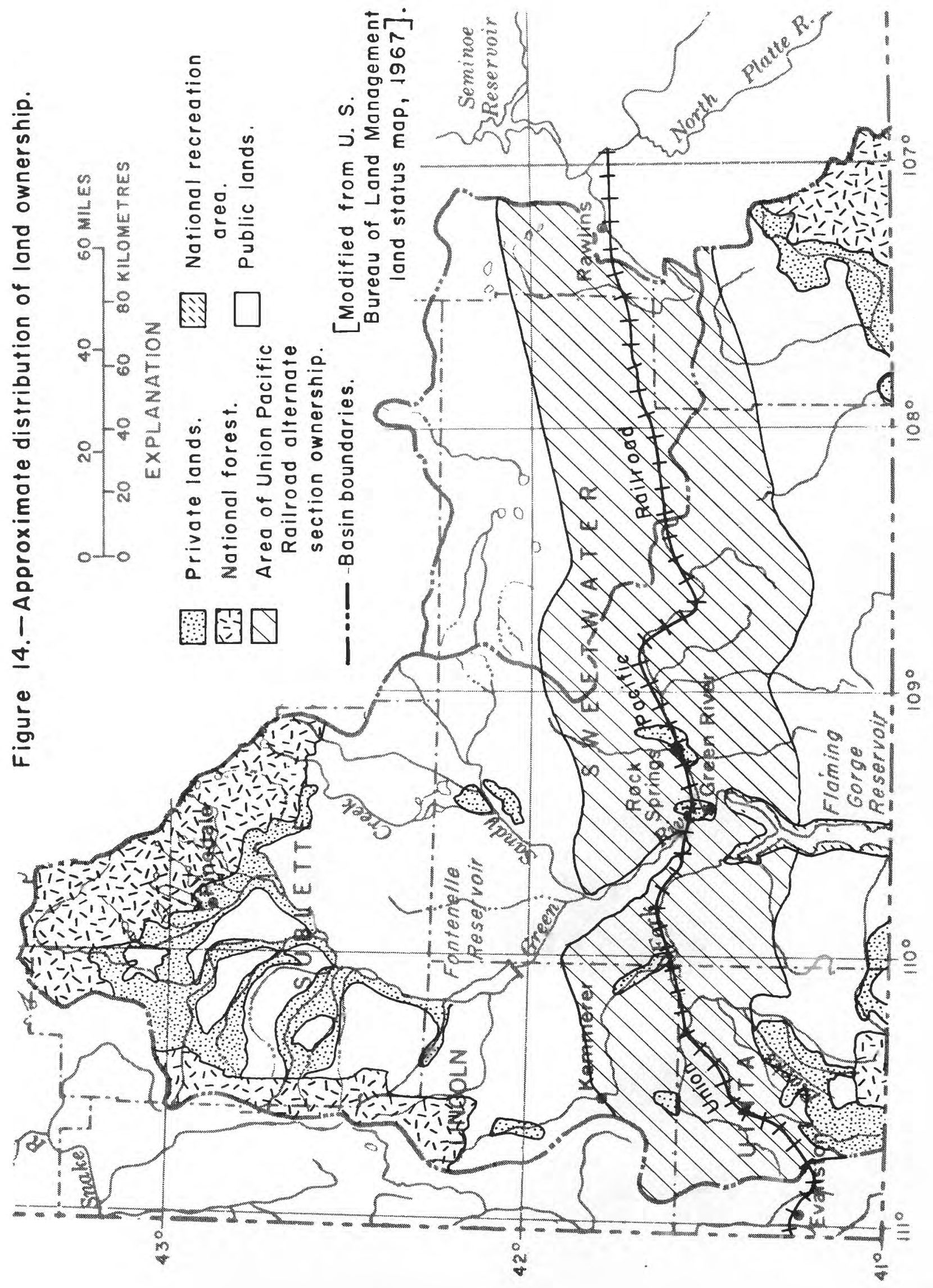


Table 4.--Land ownership in the Green River and Great Divide Basins

\begin{tabular}{ll}
$\begin{array}{l}\text { Area } \\
\text { (acres) }\end{array}$ & $\begin{array}{c}\text { Percentage of } \\
\text { land area }\end{array}$ \\
\hline
\end{tabular}

Federal lands

Forest Service $\quad 1,130,000$

Bureau of Land Management 7,861,000

Fish and Wildlife Service 12,000

Bureau of Reclamation $\quad 45,000$

Subtotal

$9,048,000$

68

State lands

Private, municipal, and

county lands

951,000

7

$3,366,000$

25

Total land area

$13,365,000$

100

Water ar'ea

88,000

Total 1 and and water area $13,453,000$ 


\section{Water Resources}

General Description of the Hydrology

The Green River, the major tributary of the Colorado River, drains the Green River Basin. The Great Divide Basin is topographically closed, and no streams flow out of it.

Most of the perennial streams in the Green River Basin originate in the mountainous areas, where the greatest precipitation occurs and where ground-water inflows sustain base flows.

Streams originating at lower elevations in the Green River Basin and those in the Great Divide Basin are ephemeral or intermittent ant flow mainly in response to direct runoff from rainstorms and snowmelt.

Streams in the Green River Basin that are important as water-supply sources contribute the major part of their annual runoff during spring and early summer as a result of snowmelt. Late summer, fall, and winter flows are mainly the result of ground-water inflow. A hydrograph of a typical perennial stream in the Green River Basin is shown in figure 15. Figure 16 shows a hydrograph of an intermittent stream in the plains area.

The quality of surface waters in the study area is generally gond. Water in the headwaters of streams is normally clear and relatively low in dissolved-solids concentrations. Concentrations increase in lower reaches of the streams as a result of natural sources of dissolved solids and man-made influences. During spring runoff, dissolved-solids concentrations typically fall below $100 \mathrm{mg} / 1$ in headwaters near mountain divides, but later in the season may rise above $200 \mathrm{mg} / 1$. Dissolvedsolids concentration in the Green River near Green River, Wyoming, normally ranges from about 300 to $600 \mathrm{mg} / 1$. During periods of low flow, dissolved-solids concentrations exceed $2,000 \mathrm{mg} / 1$ in water of a few streams that have mean discharges of less than $100 \mathrm{ft}^{3} / \mathrm{s}\left(3 \mathrm{~m}^{3} / \mathrm{s}\right)$.

Ground-water conditions in the study area are the result of climate, topography, geology, and activities of man. Recharge to ground-water reservoirs is mainly by seepage from precipitation and streams. Discharge is mainly by evaporation, seepage to streams and lakes, transpiration, and pumpage from wells. Ground water down to a depth of as much as $300 \mathrm{ft}(91 \mathrm{~m})$ below land surface is generally unconfined over most of the study area. The Green River, Wasatch, Fort Union, and older formations generally contain water under artesian pressure due to impermeable layers above and below the aquifer. The depth to water in wells that tap artesian and unconfined aquifers is generally less than $200 \mathrm{ft}$ $(60 \mathrm{~m})$, but the drilling depth to artesian aquifers exceeds $1,000 \mathrm{ft}$ $(300 \mathrm{~m})$ in the deeper parts of structural basins (Welder, 1968). Ground-water occurrence in the alluvial aquifers along streams is closely related to streamflow. 


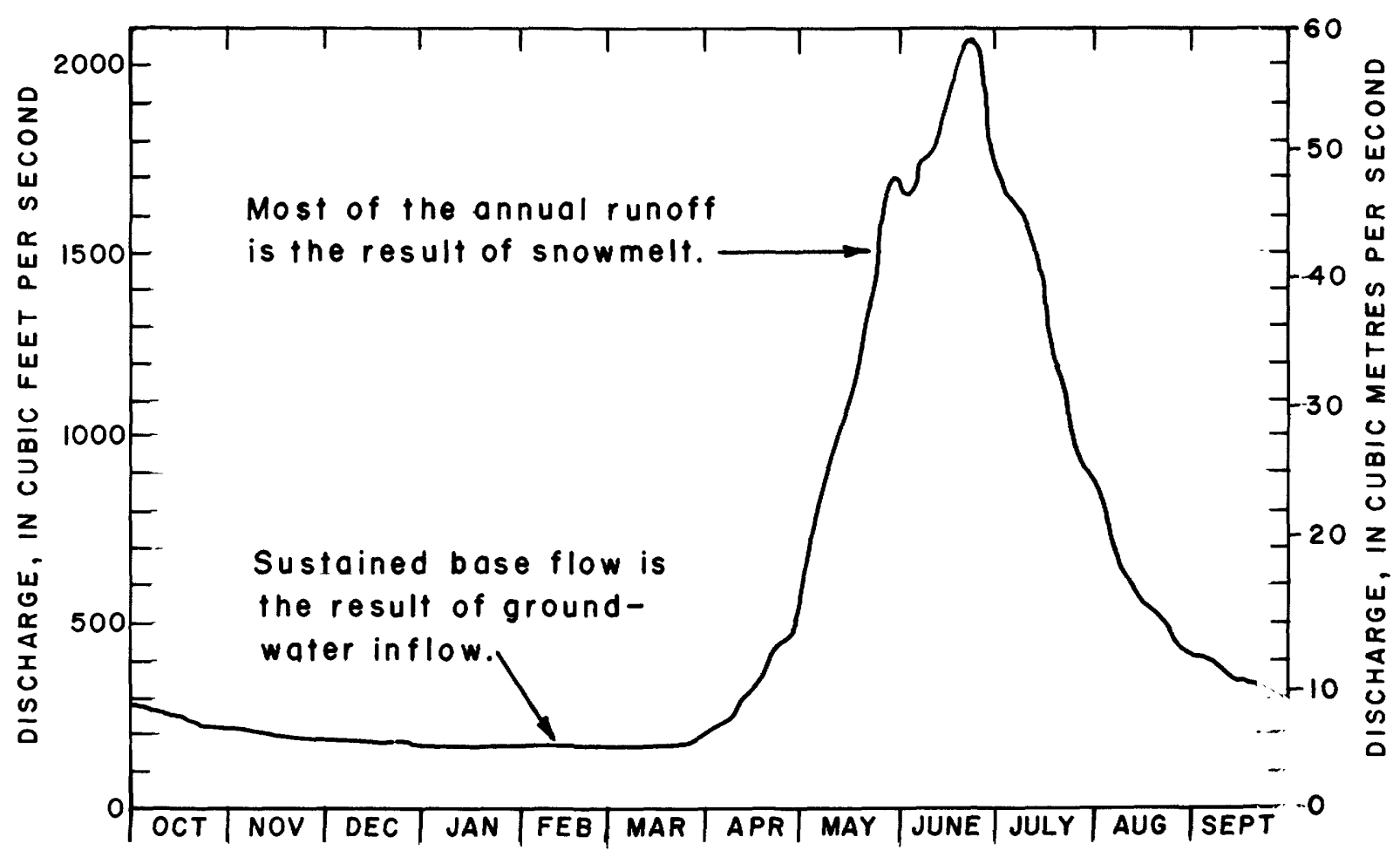

WATER YEARS $|93|-7 \mid$

Figure 15.-Mean daily discharge at station 09188500 Green River at Worren Bridge, near Doniel, Wyoming (overoge of 1931-71 woter years). 
anOJJS YZA

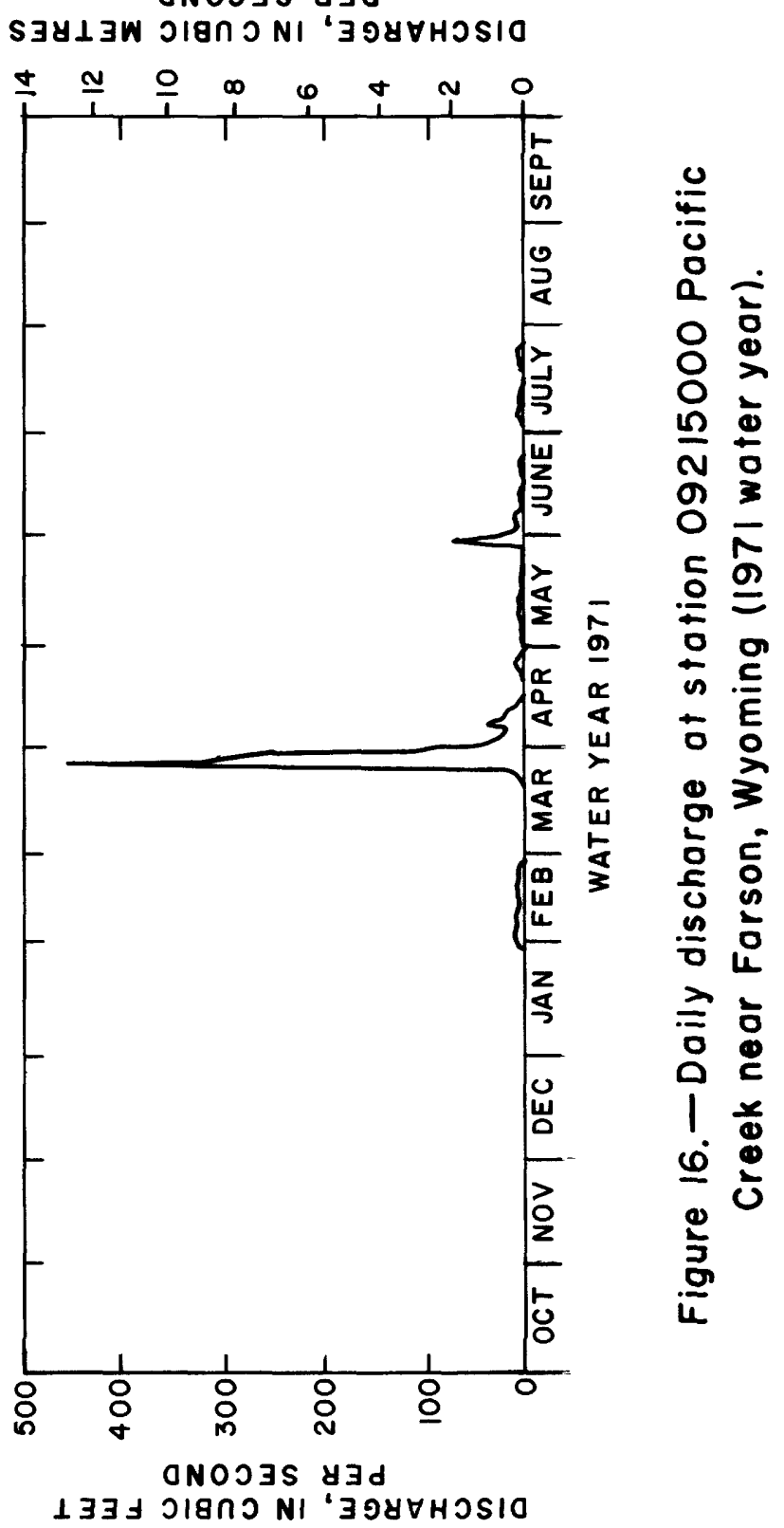


Maximum yields of existing wells in the study area range from about 1 to $500 \mathrm{gal} / \mathrm{min}\left(6 \times 10^{-2}\right.$ to $\left.301 / \mathrm{s}\right)$, but yields of most we $11 \mathrm{~s}$ range from about 10 to $100 \mathrm{ga} / \mathrm{min}(0.6$ to $6 \mathrm{l} / \mathrm{s})$. Yields greater than $500 \mathrm{gal} / \mathrm{min}$ (30 $1 / \mathrm{s})$ could probably be obtained from deep wells $(2,000$ to 5,000 ft or 600 to $1,500 \mathrm{~m}$ ) penetrating thick sandstone sections in the Wasatch and Fort Union Formations, and from shallow wells tapping some of the well-sorted alluvial and gravel deposits near Pinedale.

Water in the alluvial and gravel deposits and in the more permeable sandstone of the Wasatch Formation near the surface in the northern twothirds of Sublette County generally contains less than $500 \mathrm{mg} / 1$ dissolved solids. Ground water containing from 500 to $3,500 \mathrm{mg} / 1$ dissolved solids occurs in at least one aquifer in areas in southern Sublette County and southward. Water containing less than $1,000 \mathrm{mg} / 1$ dissolved solids may be found in about one-third of the area in the Great Divide Basin. In general, dissolved-solids concentrations increase with depth throughout the study area.

\section{Summary of Existing Data}

Water-resources programs of the U.S. Geological Survey consist of the collection of basic information at its hydrologic-data stations, areal hydrologic and interpretive studies, and research projects. The basic data collected, the results of the areal studies, and the research findings are presented mainly in publications of the U.S. Geological Survey and State agencies, but some appear also in technical journals and other publications.

Much of the data collection in the Green River and Great Divide Basins is a cooperative effort in which the planning and financial support are shared by State and local governments and other Federal agencies. Various programs are conducted in cooperation with the Wyoming State Engineer; Wyoming Department of Economic Planning anf Development; Wyoming Department of Agriculture; Wyoming Highway Commission; Wyoming Game and Fish Commission; Wyoming Department of Environmental Quality; U.S. Bureau of Reclamation; U.S. Bureau of Land Management; U.S. Army Corps of Engineers; U.S. Environmental Protention Agency; Federal Insurance Administration; and U.S. Department of Housing and Urban Development.

Hydrologic data collected by the U.S. Geological Survey as part of its basic-data programs include:
a. Streamflow records.
b. Measurements of water levels in wells.
c. Chemical analyses of water from streams and wells.
d. Biologic and bacterial analyses of water from streams.
e. Sediment analyses of water from streams. 
In addition, records of reservoir levels and contents of major reservoirs are collected by the U.S. Bureau of Reclamation and published by the U.S. Geological Survey.

Figures 17-22 show sites where hydrologic data have been collected in the study area. Tables 5-10 1ist pertinent information concerning the data sites. 


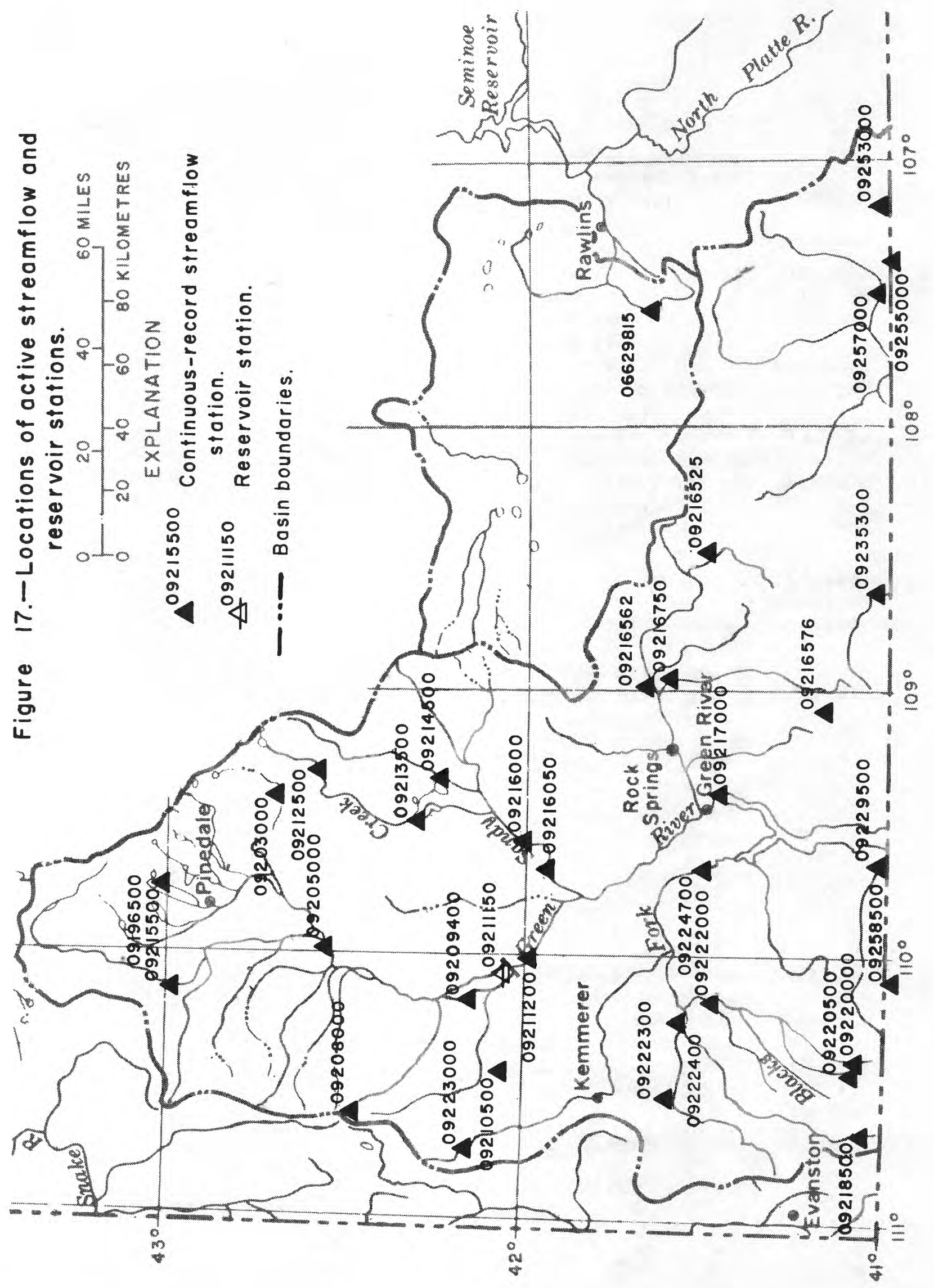


Table 5.--Active streamflow and reservoir stations

\begin{tabular}{|c|c|c|c|}
\hline $\begin{array}{l}\text { Station } \\
\text { no. }\end{array}$ & Station name & $\begin{array}{l}\text { Cooper- } \\
\text { ator }\end{array}$ & $\begin{array}{l}\text { Period of } \\
\text { record }\end{array}$ \\
\hline 06629815 & Separation Creek near Riner & BLM & $1975-$ \\
\hline 09188500 & $\begin{array}{l}\text { Green River at Warren Bridge, } \\
\text { near Daniel }\end{array}$ & WSE & 1931- \\
\hline 09196500 & Pine Creek above Fremont Lake & USGS & 1954- \\
\hline 09203000 & East Fork River near Big Sandy & WSE & 1954- \\
\hline 09205000 & New Fork River near Big Piney & WSE & $1954-$ \\
\hline 09208000 & $\begin{array}{l}\text { La Barge Creek near La Barge Meadows } \\
\text { ranger station }\end{array}$ & USGS & $1940-42,1950-$ \\
\hline 09209400 & Green River near La Barge & WSE & 1963- \\
\hline 09210500 & $\begin{array}{l}\text { Fontenelle Creek near Herschler Ranch, } \\
\text { near Fontenelle }\end{array}$ & USGS & 1951- \\
\hline 09211150 & Fontenelle Reservoir near Fontenelle & & 1964- \\
\hline 09211200 & Green River below Fontenelle Reservoir & BRUC & 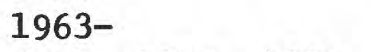 \\
\hline 09212500 & $\begin{array}{l}\text { Big Sandy River at Leckie Ranch, } \\
\text { near Big Sandy }\end{array}$ & WSE & $1910,1911,1939-$ \\
\hline 09213500 & Big Sandy River near Farson & WSE & $\begin{array}{l}1914-17,1920-24 \\
1926-34,1953-\end{array}$ \\
\hline 09214500 & Little Sandy Creek above Eden & BLM & $1954-$ \\
\hline 09216000 & Big Sandy River below Eden & BRUC & 1954- \\
\hline 09216050 & $\begin{array}{l}\text { Big Sandy River at Gasson Bridge, } \\
\text { near Eden }\end{array}$ & BRUC & 1972- \\
\hline 09216525 & Bitter Creek near Bitter Creek & BLM & 1975- \\
\hline 09216562 & $\begin{array}{l}\text { Bitter Creek above Salt Wells Creek, } \\
\text { near Salt Wells }\end{array}$ & BLM & 1975- \\
\hline 09216576 & $\begin{array}{l}\text { Gap Creek below Beans Spring Creek, } \\
\text { near South Baxter }\end{array}$ & BLM & 1975- \\
\hline 09216750 & Salt Wells Creek near Salt Wells & BLM & 1975- \\
\hline 09217000 & Green River near Green River & USGS & 1951- \\
\hline 09218500 & Blacks Fork near Millburne & WSE & 1939- \\
\hline 09220000 & E F of Smith Fork near Robertson & WSE & 1939- \\
\hline 09220500 & W F of Smith Fork near Robertson & WSE & 1939- \\
\hline 09222000 & Blacks Fork near Lyman & BRUC & $1937-57,1962-$ \\
\hline 09222300 & Little Muddy Creek near Glencoe & BLM & $1975-$ \\
\hline 09222400 & Muddy Creek near Hampton & BLM & 1975- \\
\hline 09223000 & Hams Fork below Pole Creek, nr Frontier & USGS & 1952- \\
\hline 09224700 & Blacks Fork near Little America & USGS & 1962- \\
\hline 09228500 & Burnt Fork near Burntfork & WSE & 1943- \\
\hline 09229500 & Henrys Fork near Manila, Utah & USGS & 1928- \\
\hline 09235300 & Vermillion Creek near Hiawatha, Colo. & BLM & $1975-$ \\
\hline 09253000 & Little Snake River near Slater, Colo. & & $1942-47,1950-$ \\
\hline 09255000 & Slater Fork near Slater, Colo. & & $1931-$ \\
\hline 09257000 & Little Snake River near Dixon & WSE & $1910-23,1938-$ \\
\hline
\end{tabular}

a/ Cooperators: BLM Bureau of Land Management.

BRUC Bureau of Reclamation, Upper Colorado Region,

Salt Lake City, Utah.

USGS U.S. Geological Survey.

WSE Wyoming State Engineer. 
을

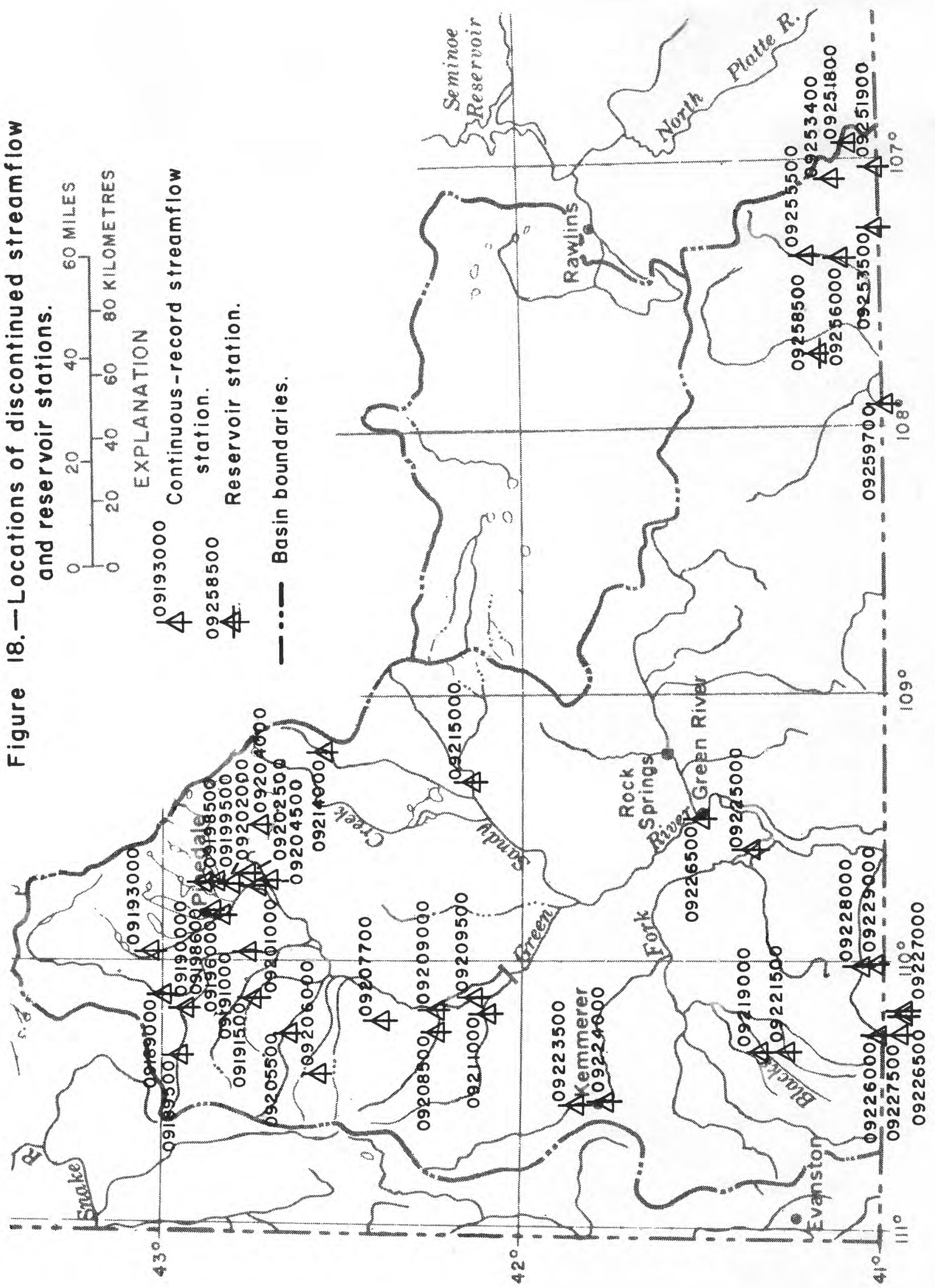


Table 6.--Discontinued streamflow and reservoir stations

(Stations with at least 5 years of record.)

\begin{tabular}{|c|c|c|}
\hline station & Station name & Period of record \\
\hline 09189000 & Beaver Creek near Daniel & $1938-54$ \\
\hline 09189500 & Horse Creek at Sherman ranger station & $1954-73$ \\
\hline 09190000 & Horse Creek near Daniel & $1931-54$ \\
\hline 09191000 & Green River near Daniel & $1912-32$ \\
\hline 09191500 & Cottonwood Creek near Daniel & $1938-54$ \\
\hline 09193000 & $\begin{array}{l}\text { New Fork River below New Fork Lake, } \\
\text { near Cora }\end{array}$ & $1938-72$ \\
\hline 09196000 & New Fork River near Pinedale & $1938-44$ \\
\hline 09198000 & Pine Creek at Pinedale & $1903-04,1914-54$ \\
\hline 09198500 & $\begin{array}{l}\text { Pole Creek below Little Half Moon Lake, } \\
\text { near Pinedale }\end{array}$ & $1938-71$ \\
\hline 09199500 & Fal1 Creek near Pinedale & $1938-71$ \\
\hline 09201000 & New Fork River near Boulder & $1914-69$ \\
\hline 09202000 & $\begin{array}{l}\text { Boulder Creek below Boulder Lake, } \\
\text { near Boulder }\end{array}$ & $1938-73$ \\
\hline 09202500 & Boulder Creek near Boulder & $\begin{array}{l}1903-06,1914-24, \\
1930-32\end{array}$ \\
\hline 09204000 & Silver Creek near Big Sandy & $1938-71$ \\
\hline 09204500 & East Fork at New Fork & $\begin{array}{l}1904-06,1914-24, \\
1930-32\end{array}$ \\
\hline 09205500 & North Piney Creek near Mason & $1915-16,1931-72$ \\
\hline 09206000 & $\begin{array}{l}\text { Middle Piney Creek below South Fork, } \\
\text { near Big Piney }\end{array}$ & $1939-54$ \\
\hline 09207700 & Dry Piney Creek near Big Piney & $1965-73$ \\
\hline 09208500 & La Barge Creek near Viola & $1913-16,1940-49$ \\
\hline 09209000 & La Barge Creek near La Barge & $1931-39$ \\
\hline 09209500 & Green River near Fontenelle & $1946-65$ \\
\hline 09211000 & Fontenelle Creek near Fontenelie & $1931-53$ \\
\hline 09214000 & Little Sandy Creek near E1khorn & $1939-71$ \\
\hline 09215000 & Pacific Creek near Farson & $1954-73$ \\
\hline 09216500 & Green River at Green River & $\begin{array}{l}1891,1894-1906 \\
1914-45\end{array}$ \\
\hline 09219000 & Blacks Fork near Urie & $1913-24,1937-55$ \\
\hline 09221500 & Smith Fork at Mountain View & $1941-57$ \\
\hline 09223500 & Hams Fork near Frontier & $1945-72$ \\
\hline 09224000 & Hams Fork at Diamondville & $1917-33,1945-49$ \\
\hline 09225000 & Blacks Fork near Green River & $1947-62$ \\
\hline 09226000 & Henrys Fork near Lonetree & $1942-72$ \\
\hline 09226500 & Middle Fork Beaver Creek near Lonetree & $1948-70$ \\
\hline 09227000 & East Fork Beaver Creek near Lonetree & $1948-62$ \\
\hline 09227500 & West Fork Beaver Creek near Lonetree & $1948-62$ \\
\hline 09228000 & Henrys Fork near Burntfork & $1942-54$ \\
\hline 09229000 & Burnt Fork at Burntfork & $1929-43$ \\
\hline
\end{tabular}


Table 6.--Discontinued streamflow and reservoir stations--continued

\begin{tabular}{lll}
\hline Station & \multicolumn{1}{c}{ Station name } & Period of record \\
\hline 09251800 & $\begin{array}{c}\text { North Fork Little Snake River near } \\
\text { Encampment }\end{array}$ & $1956-65$ \\
09251900 & $\begin{array}{c}\text { North Fork Little Snake River near } \\
\text { Slater, Colo. }\end{array}$ & $1956-63$ \\
09253400 & Battle Creek near Encampment & $1956-63$ \\
09253500 & Battle Creek near Slater, Colo. & $1942-51$ \\
09255500 & Savery Creek at upper station, near Savery & $1940-44,1952-71$ \\
09256000 & Savery Creek near Savery & $1941-46,1947-72$ \\
09258500 & Little Robber Reservoir & $1954-62$ \\
09259700 & Little Snake River near Baggs & $1961-68$ \\
\hline
\end{tabular}



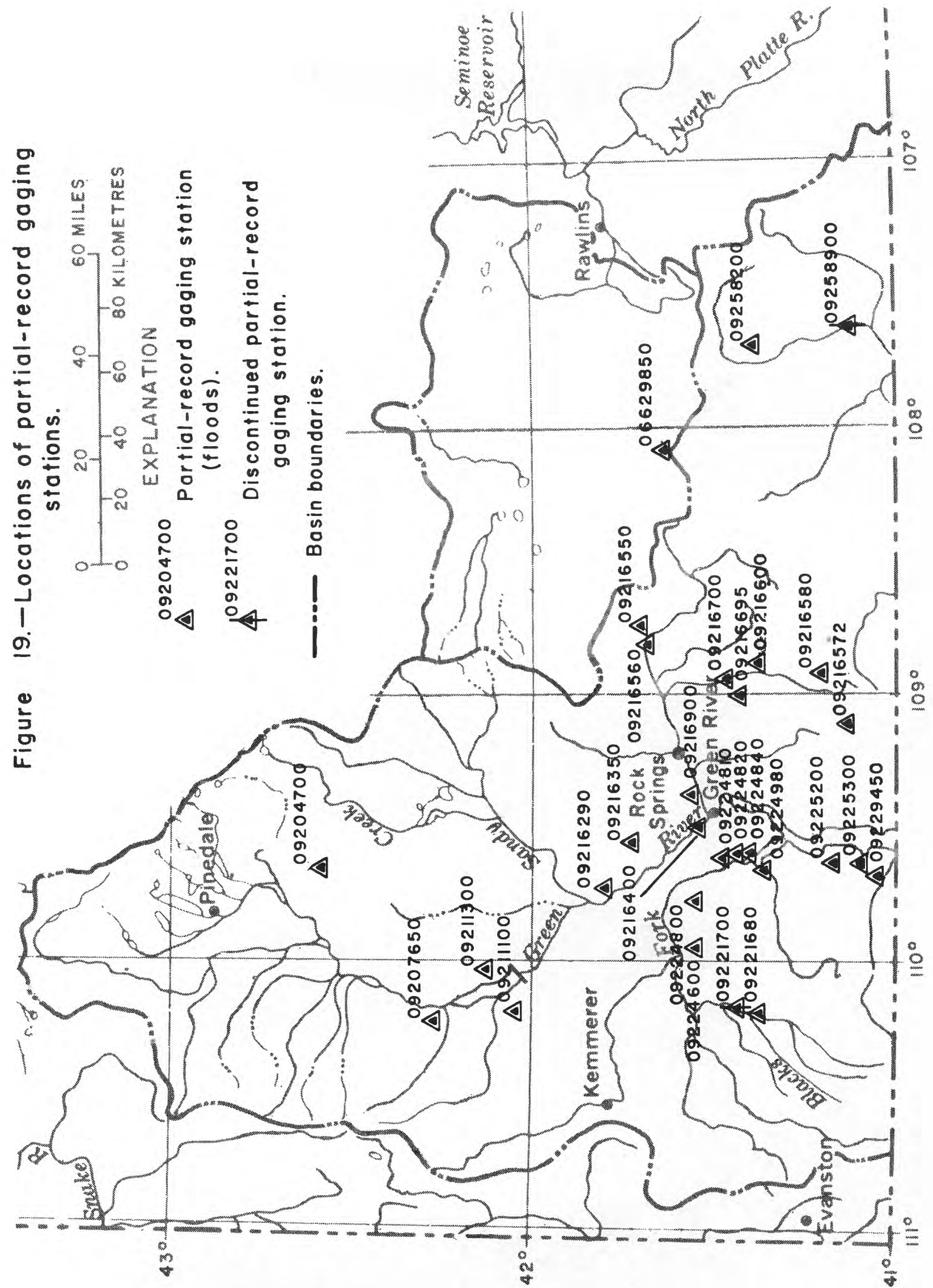
Table 7.--Partial-record gaging stations

\begin{tabular}{|c|c|c|}
\hline $\begin{array}{l}\text { Station } \\
\text { no. }\end{array}$ & Station name & Period of record \\
\hline \multicolumn{3}{|c|}{ Great Divide Basin } \\
\hline 06629850 & Delaney Draw near Red Desert & 1961- \\
\hline \multicolumn{3}{|c|}{ Green River Basin } \\
\hline 09204700 & Sand Springs Draw tributary near Boulder & 1961- \\
\hline 09207650 & Dry Basin Creek near Big Piney & 1971- \\
\hline 09211100 & Green River tributary near Fontenelle & 1961-74 \\
\hline 09211300 & Fourmile Gulch tributary near Fontenelle & $1971-$ \\
\hline 09216290 & E Otterson Wash near Green River & 1970- \\
\hline 09216350 & Skunk Canyon Creek near Green River & $1965,1971-$ \\
\hline 09216400 & Greasewood Canyon near Green River & $1959-$ \\
\hline 09216550 & Deadman Wash near Point of Rocks & 1961- \\
\hline 09216560 & Bitter Creek near Point of Rocks & 1961- \\
\hline 09216572 & Bean Spring Creek near South Baxter & 1975- \\
\hline 09216580 & Big Flat Draw near Rock Springs & $1972-$ \\
\hline 09216600 & $\begin{array}{l}\text { Salt Wells Creek tributary near } \\
\text { Rock Springs }\end{array}$ & $\begin{array}{l}1959-70,1970-72, \\
1972-\end{array}$ \\
\hline 09216695 & No Name Creek near Rock Springs & $1972-$ \\
\hline 09216700 & Salt Wells Creek near Rock Springs & 1959- \\
\hline 09216900 & Bitter Creek tributary near Green River & $1959-$ \\
\hline 09221680 & $\begin{array}{l}\text { Mud Spring Hollow near Church Butte, } \\
\text { near Lyman }\end{array}$ & $1965-73,1973-$ \\
\hline 09221700 & Mud Spring Hollow near Lyman & 1959-71 \\
\hline 09224600 & Blacks Fork tributary near Granger & $1959-$ \\
\hline 09224800 & $\begin{array}{l}\text { Meadow Springs Wash tributary near } \\
\text { Green River }\end{array}$ & $1962-65,1968-$ \\
\hline 09224810 & $\begin{array}{l}\text { Blacks Fork tributary No. } 2 \text { near } \\
\text { Green River }\end{array}$ & 1965- \\
\hline 09224820 & $\begin{array}{l}\text { Blacks Fork tributary No. } 3 \text { near } \\
\text { Green River }\end{array}$ & 1965- \\
\hline 09224840 & $\begin{array}{l}\text { Blacks Fork tributary No. } 4 \text { near } \\
\text { Green River }\end{array}$ & 1965- \\
\hline 09224980 & Summers Dry Creek near Green River & 1965- \\
\hline 09225200 & Squaw Hollow near Burntfork & 1965- \\
\hline 09225300 & Green River tributary No. 2 near Burntfork & $1959,1961-$ \\
\hline 09229450 & Henrys Fork tributary near Manila, Utah & $1965-74$ \\
\hline 09258200 & Dry Cow Creek near Baggs & 1970- \\
\hline 09258900 & Muddy Creek above Baggs & $1958-71$ \\
\hline
\end{tabular}

Cooperator for partial-record stations: Wyoming Highway Department. 


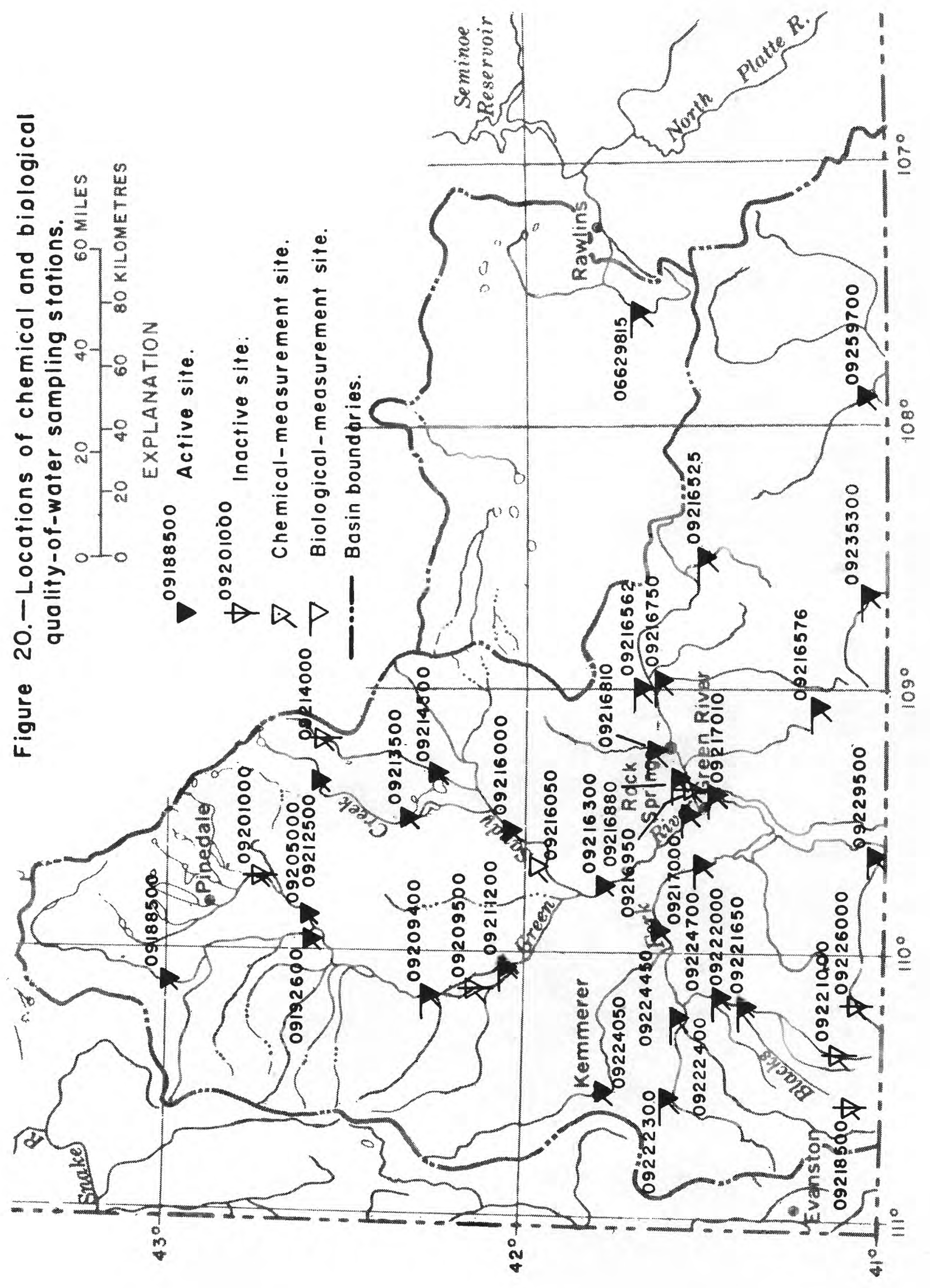


Table 8.--Chemical and biological quality-of-water sampling stations.

\begin{tabular}{|c|c|c|c|c|c|}
\hline Station & Name & $\begin{array}{l}\text { Cooper-a/ } \\
\text { ators }-\end{array}$ & $\begin{array}{l}\text { Param- } \text { b/ } \\
\text { eters }-\end{array}$ & $\begin{array}{l}\text { Period of } \\
\text { record }\end{array}$ & \\
\hline 06629815 & Separation Creek near Riner & BLM & $1,4,5$ & $1975-$ & \\
\hline 09188500 & $\begin{array}{l}\text { Green River at Warren Bridge, } \\
\text { nr Daniel }\end{array}$ & WDEQ & $1,5,6$ & $\begin{array}{l}\text { 1962-64, } \\
1967-73\end{array}$ & 1974- \\
\hline 09192600 & Green River nr Big Piney & WDA & 1 & $1967-$ & \\
\hline 09201000 & New Fork River nr Boulder & ------ & 1 & $1967-71$ & \\
\hline 09205000 & New Fork River nr Big Piney & WDA & 1 & $1965-$ & \\
\hline 09209400 & Green River nr La Barge & WDA, WDEQ & $1,2,3,5,6$ & 1963- & \\
\hline 09209500 & Green River nr Fontenelle & $--\infty-\infty$ & 1 & $1962-63$ & \\
\hline 09211200 & $\begin{array}{l}\text { Green River b1 Fontenelle } \\
\text { Reservoir }\end{array}$ & WDA, & $1,2,3,5,6$ & 1967- & \\
\hline 09212500 & $\begin{array}{l}\text { Big Sandy River } \\
\text { at Leckie Ranch }\end{array}$ & & 1 & $1961-62$, & 1975- \\
\hline 09213500 & Big Sandy River nr Farson & - - - - - & 1 & 1962-64, & 1975- \\
\hline 09214000 & Little Sandy Creek nr E1khorn & -ーーーー-ー & 1 & 1961-62, & 1975- \\
\hline 09214500 & Little Sandy Creek nr Eden & -------- & 1 & $1962-64$ & \\
\hline 09216000 & Big Sandy River b1 Eden & WDA & 1 & 1961-64, & 1967- \\
\hline 09216050 & $\begin{array}{l}\text { Big Sandy River at Gasson } \\
\text { Bridge, near Eden }\end{array}$ & USGS & 1,5 & 1975- & \\
\hline 09216300 & $\begin{array}{l}\text { Green River at Big Island, } \\
\text { nr Green River }\end{array}$ & WDA, WDEQ & $1,5,6$ & 1966- & \\
\hline 09216525 & Bitter Creek nr Bitter Creek & BLM & $1,4,5$ & 1975- & \\
\hline 09216562 & $\begin{array}{l}\text { Bitter Creek ab Salt Wells } \\
\text { Creek, nr Salt Wells }\end{array}$ & BLM & $1,4,5$ & 1975- & \\
\hline 09216576 & $\begin{array}{l}\text { Gap Creek bl Beans Spring Cr, } \\
\text { nr South Baxter }\end{array}$ & BLM & $1,4,5$ & $1975-$ & \\
\hline 09216750 & $\begin{array}{l}\text { Salt Wells Creek near } \\
\text { Salt Wells }\end{array}$ & BLM & $1,4,5$ & 1975- & \\
\hline 09216810 & $\begin{array}{l}\text { Killpecker Creek at } \\
\text { Rock Springs }\end{array}$ & EPA & $1,4,5$ & $1975-$ & \\
\hline 09216880 & $\begin{array}{l}\text { Bitter Creek bel Little Bitter } \\
\text { Creek, nr Kanda }\end{array}$ & EPA & $1,4,5$ & $1975-$ & \\
\hline 09216950 & Bitter Creek nr Green River & $-m-\cdots$ & 1,5 & $1966-72$ & \\
\hline 09217000 & Green River nr Green River & USGS, WDEQ & $1,2,3,5,6$ & $1951-$ & \\
\hline 09217010 & Green River bl Green River & WDEQ & $1,5,6$ & 1974- & \\
\hline 09218500 & Blacks Fork nr Millburne & $-\infty-\infty$ & 1,5 & $1969-70$ & \\
\hline 09221000 & Smith Fork nr Robertson & $-\infty-\infty-\infty$ & 1,5 & $1969-70$ & \\
\hline 09221650 & Smiths Fork nr Lyman & WDEQ & $1,5,6$ & $1974-$ & \\
\hline 09222000 & Blacks Fork nr Lyman & BRUC, WDEQ & $1,2,3,5,6$ & $1962-$ & \\
\hline 09222300 & Little Muddy Creek nr Glencoe & BLM & $1,4,5$ & 1975- & \\
\hline 09222400 & Muddy Creek nr Hampton & BLM & $1,4,5$ & 1975- & \\
\hline 09224050 & Hams Fork nr Diamondville & EPA & $1,2,3,5,6$ & 1975- & \\
\hline 09224450 & Hams Fork nr Granger & WDA & 1 & 1965- & \\
\hline 09224700 & $\begin{array}{l}\text { Blacks Fork nr Little } \\
\text { America }\end{array}$ & USGS, WDEQ & $1,2,3,5,6$ & $1961-$ & \\
\hline 09226000 & Henrys Fork nr Lonetree & $-\cdots$ & 1,5 & $1969-72$ & \\
\hline
\end{tabular}


Table 8.--Chemical and biological quality-of-water sampling stations--continued

\begin{tabular}{llccc}
\hline Station & \multicolumn{1}{c}{ Name } & $\begin{array}{l}\text { Cooper-a/ } \\
\text { ators }\end{array}$ & $\begin{array}{c}\text { Param- } \\
\text { eters } \text { / Period of } \\
\text { record }\end{array}$ \\
09228500 & Burnt Fork nr Burnt Fork & $-1969-70$ \\
09229500 & Henrys Fork nr Manila, Utah & USGS & $1,2,3$ & $1951-$ \\
09235300 & Vermillion Creek nr Hiawatha, & BLM & $1,4,5$ & $1975-$ \\
09259700 & Little Snake River nr Baggs & WDA & 1 & $1965-$
\end{tabular}

a/ Cooperators: BLM U.S. Bureau of Land Management.

WDEQ Wyoming Department of Environmenta1 Quality.

WDA Wyoming Department of Agriculture.

USGS U.S. Geological Survey.

BRUC U.S. Bureau of Reclamation - Upper Colorado Region.

b/ Parameters: 1 Salinity (major constituents).

2 Daily specific conductance.

3 Daily temperature (observed).

4 Bacteria or chemical oxygen demand.

5 Field determinations of: $\mathrm{pH}$, specific conductance,

dissolved oxygen, temperature, and (or) turbidity.

6 Fecal coliform and (or) fecal streptococcus

and total coliform.

NOTE: As part of the Green River Basin project, specific conductance and turbidity will be measured monthly at all active continuousand partial-record gaging stations. 


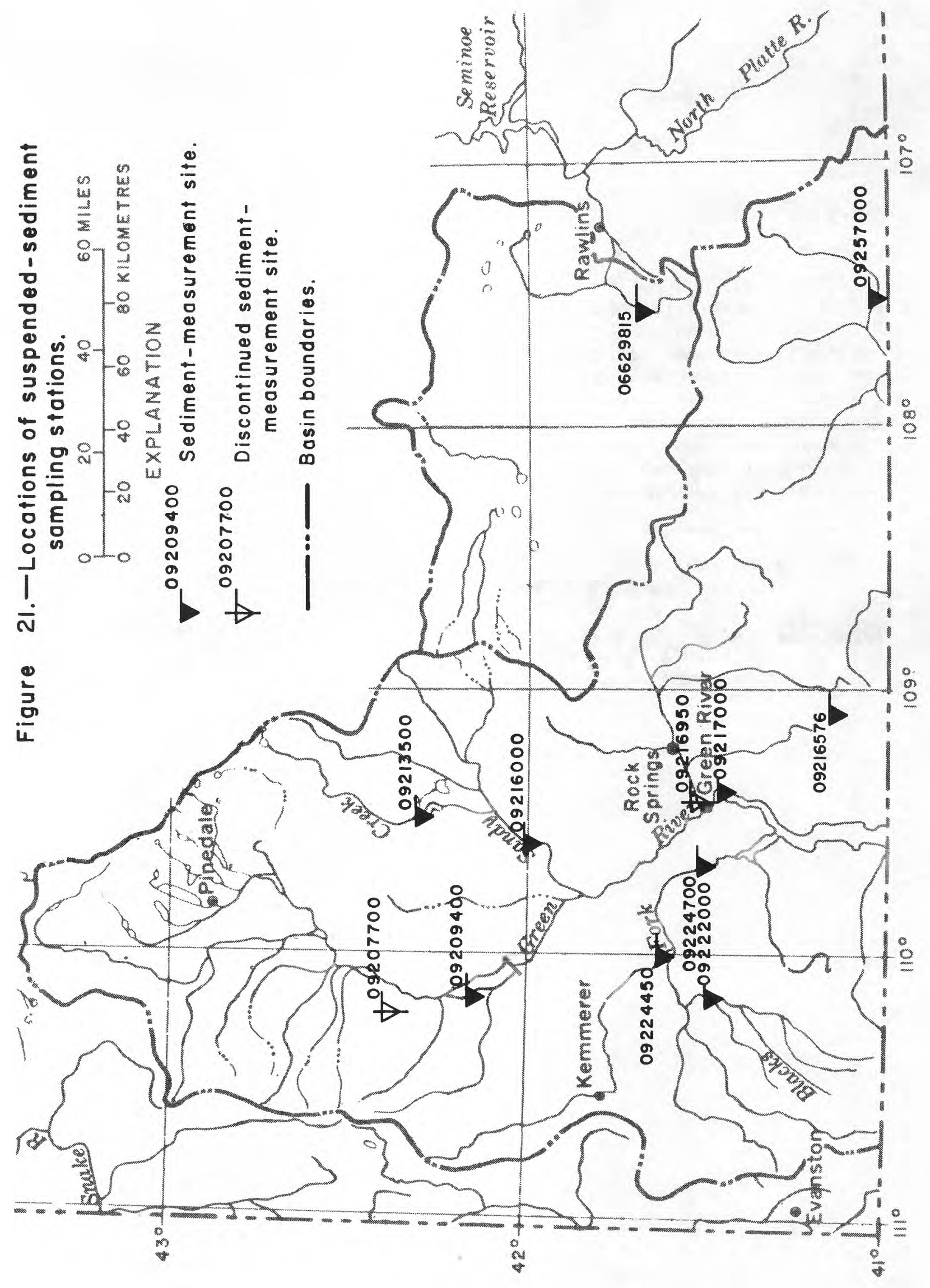


Table 9.-- Suspended-sediment samp1ing stations

\begin{tabular}{|c|c|c|c|}
\hline $\begin{array}{c}\begin{array}{c}\text { Station } \\
\text { no. }\end{array} \\
\end{array}$ & Station name & $\begin{array}{l}\text { Cooper- } \\
\text { ator al }\end{array}$ & $\begin{array}{l}\text { Period of } \\
\text { record }\end{array}$ \\
\hline 09207700 & Dry Piney Creek near Big Piney & & $1966-71$ \\
\hline 09209400 & Green River near La Barge & WSE & 1974- \\
\hline 09213500 & Big Sandy River near Farson & WSE & 1971- \\
\hline 09216000 & Big Sandy River below Eden & WSE & 1971- \\
\hline 09216950 & Bitter Creek near Green River & & $1966-72$ \\
\hline 09217000 & Green River near Green River & USGS & 1951- \\
\hline 09222000 & Blacks Fork near Lyman & WSE & 1971- \\
\hline 09224450 & Hams Fork near Granger & WSE & 1971- \\
\hline 09224700 & Blacks Fork near Little America & WSE & 1967- \\
\hline 09257000 & Little Snake River near Dixon & WSE & 1971- \\
\hline
\end{tabular}

\section{al Cooperators: USGS U.S. Geological Survey. WSE Wyoming State Engineer.}

NOTE: As part of the Green River Basin project, suspended sediment and turbidity will be measured monthly at all active continuousand partial-record gaging stations. 


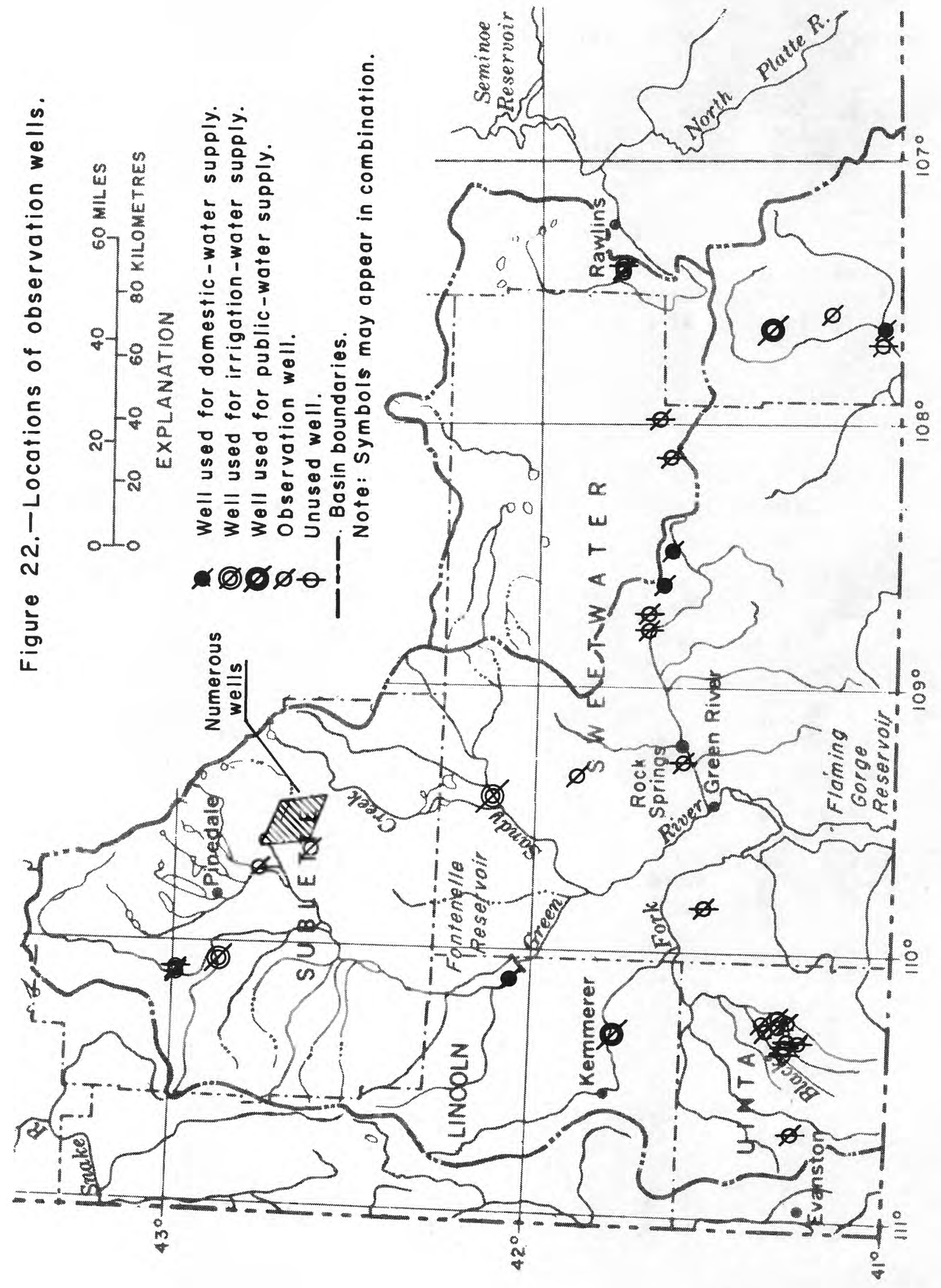


Table 10.--Observation we1ls

\begin{tabular}{clll}
\hline $\begin{array}{c}\text { We11 no. } \\
\text { and } \\
\text { location }\end{array}$ & $\begin{array}{l}\text { We11 } \\
\text { depth } \\
(\mathrm{ft})\end{array}$ & $\begin{array}{l}\text { Use of Geologic } \\
\text { water } \stackrel{\text { al }}{\text { source }} \underline{\mathrm{b}} \text { / }\end{array}$ & $\begin{array}{l}\text { Cooper- } \\
\text { ators } \underline{c} \text { / Records available }\end{array}$ \\
\hline
\end{tabular}

CARBON COUNTY

\begin{tabular}{lrllll}
\hline $12-91-5 \mathrm{dcb}$ & 50 & $\mathrm{H}$ & 111 ALVL & & $1965-69$ \\
$12-92-1 \mathrm{abb}$ & 136 & $\mathrm{U}$ & 111 ALVL & & $1963-64$ \\
$14-92-12 \mathrm{ac}$ & 110 & $\mathrm{~S}$ & 124 WSTC & & $1963-65$ \\
$16-92-17 \mathrm{dbb}$ & 330 & $\mathrm{P}$ & 125 FRUN & $1963-65$ \\
$21-89-22 \mathrm{ada}$ & 156 & $\mathrm{U}$ & 125 FRUN & WSE & $1963,1965-$ \\
$22 \mathrm{bc}$ & 340 & $\mathrm{~S}$ & 125 FRUN & & $1963-64$ \\
\hline
\end{tabular}

LINCOLN COUNTY

\begin{tabular}{llcllll}
\hline $21-114-26 \mathrm{bdb}$ & 180 & $\mathrm{P}$ & 124 LNEY & WSE & $1965-$ \\
$24-112-8 \mathrm{ccb}$ & 150 & $\mathrm{H}, \mathrm{P}$ & 124 LNEY & WSE & $1966-70,1972-$ \\
\hline
\end{tabular}

SUBLETTE COUNTY

\begin{tabular}{rrrlll}
\hline 28-112-19ac & 153 & $\mathrm{U}$ & 124 WSTC & WSE & $1965-70,1972-$ \\
$30-106-2 \mathrm{ccc}$ & 67 & $\mathrm{U}$ & 111 ALVL & & $1966-67$ \\
$3 \mathrm{bbc}$ & 8 & $\mathrm{U}$ & 111 ALVL & & $1966-67$ \\
$4 \mathrm{ddd}$ & 50 & $\mathrm{U}$ & 111 ALVL & & $1965-68$ \\
$10 \mathrm{bcc}$ & 50 & $\mathrm{U}$ & 111 ALVL & & $1966-67$ \\
$10 \mathrm{ccc}$ & 27 & $\mathrm{U}$ & 111 ALVL & & $1965-68$ \\
$12 \mathrm{ad}$ & 102 & $\mathrm{~S}$ & 124 WSTC & & $1966-67$ \\
$13 \mathrm{acc}$ & 62 & $\mathrm{U}$ & 111 ALVL & & $1966-67$ \\
$22 \mathrm{bd}$ & 101 & $\mathrm{~S}$ & 124 WSTC & & $1966-67$ \\
$30-107-6 \mathrm{dd}$ & 153 & $\mathrm{~S}$ & 124 WSTC & WSE & $1964-66,1968-$ \\
$30-108-5 \mathrm{bcd1}$ & 5,200 & $\mathrm{U}$ & 125 FRUN & USGS & $1973-$ \\
$5 \mathrm{bcd} 2$ & 2,300 & $\mathrm{U}$ & 124 WSTC & USGS & $1973-$ \\
$30-111-17 \mathrm{aca}$ & 435 & $\mathrm{P}$ & 124 WSTC & WSE & $1965-$ \\
$31-106-5 \mathrm{cad}$ & 59 & $\mathrm{U}$ & 111 ALVL & & $1965-68$ \\
$6 \mathrm{aad}$ & 30 & $\mathrm{U}$ & 111 ALVL & & $1965-68$ \\
$6 \mathrm{cbb}$ & 47 & $\mathrm{U}$ & 111 ALVL & & $1966-68$ \\
$8 \mathrm{cdc}$ & 37 & $\mathrm{U}$ & 111 ALVL & & $1966-67$ \\
$17 \mathrm{cbc}$ & 72 & $\mathrm{U}$ & 111 ALVL & & $1966-67$ \\
$17 \mathrm{dad}$ & 25 & $\mathrm{U}$ & 111 ALVL & & $1965-68$ \\
$19 \mathrm{bab}$ & 42 & $\mathrm{U}$ & 111 ALVL & & $1966-67$ \\
$20 \mathrm{cbc}$ & 57 & $\mathrm{U}$ & 111 ALVL & & $1965-68$ \\
$20 \mathrm{ddc}$ & 61 & $\mathrm{U}$ & 111 ALVL & & $1965-68$ \\
$28 \mathrm{cdd}$ & 50 & $\mathrm{U}$ & 111 ALVL & & $1966-67$ \\
$32 \mathrm{aba}$ & 50 & $\mathrm{P}$ & 124 WSTC & & $1965-68$ \\
$33 \mathrm{bca}$ & 8 & $\mathrm{U}$ & 111 ALVL & & $1965-68$ \\
$33 \mathrm{daa}$ & 33 & $\mathrm{U}$ & 111 ALVL & & $1965-68$
\end{tabular}


Table 10.--Observation wells--continued

\begin{tabular}{|c|c|c|c|c|c|}
\hline $\begin{array}{l}\text { Well no. } \\
\text { and } \\
\text { location }\end{array}$ & $\begin{array}{l}\text { Well } \\
\text { depth } \\
\text { (ft) }\end{array}$ & $\begin{array}{l}\text { Use of } \\
\text { water } \underline{a} /\end{array}$ & $\begin{array}{l}\text { Geologic } \\
\text { source } b /\end{array}$ & $\begin{array}{l}\text { Cooper- } \\
\text { ators } \text { cl }\end{array}$ & Records available \\
\hline & \multicolumn{5}{|c|}{ SUBLETTE COUNTY--continued } \\
\hline $\begin{array}{r}31-107-1 \mathrm{aaa} \\
1 \mathrm{bbb} \\
1 \mathrm{dcc} \\
2 \mathrm{dab} \\
11 \mathrm{acb} \\
13 \mathrm{baa} \\
23 \mathrm{dc} \\
24 \mathrm{bda} \\
32-106-31 \mathrm{aac} \\
32 \mathrm{dca} \\
32-107-15 \mathrm{dca} \\
22 \mathrm{dcc} \\
23 \mathrm{cda} \\
25 \mathrm{aad} \\
25 \mathrm{add} \\
25 \mathrm{ccc} \\
26 \mathrm{add} \\
35 \mathrm{ccb} \\
32-108-5 \mathrm{ba} \\
34-111-35 \mathrm{cb} \\
35-111-8 \mathrm{adb} \\
8 \mathrm{db} \\
\end{array}$ & $\begin{array}{r}37 \\
60 \\
65 \\
62 \\
33 \\
62 \\
133 \\
32 \\
25 \\
75 \\
29 \\
57 \\
30 \\
85 \\
26 \\
27 \\
32 \\
37 \\
77 \\
117 \\
39 \\
32\end{array}$ & $\begin{array}{l}U \\
U \\
U \\
U \\
U \\
U \\
U \\
U \\
U \\
S \\
U \\
U \\
U \\
U \\
U \\
U \\
U \\
U \\
U \\
P \\
U \\
U\end{array}$ & 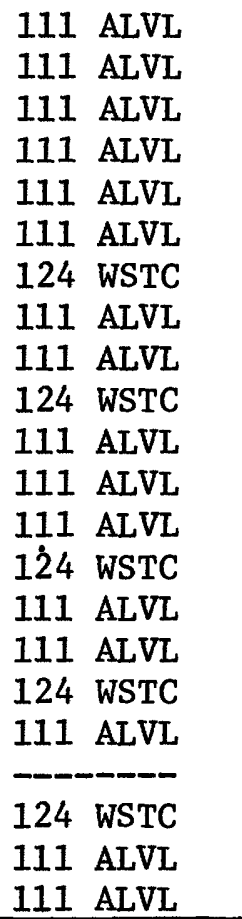 & $\begin{array}{l}\text { WSE } \\
\text { USGS }\end{array}$ & $\begin{array}{l}1965-68 \\
1965-68 \\
1966-67 \\
1965-68 \\
1965-68 \\
1966-67 \\
1966-67 \\
1966-67 \\
1966-67 \\
1966-67 \\
1965-68 \\
1966-67 \\
1966-67 \\
1966-68 \\
1965-67 \\
1965-68 \\
1965-68 \\
1966-67 \\
1965- \\
1966-69 \\
1965- \\
1942-65\end{array}$ \\
\hline \multicolumn{6}{|c|}{ SWEETWATER COUNTY } \\
\hline $\begin{array}{l}18-110-21 \mathrm{dba} \\
19-95-5 \mathrm{dd} \\
19-98-8 \mathrm{ca} \\
19-99-6 \mathrm{dcc} \\
19-105-32 \mathrm{dab} \\
20-94-34 \mathrm{bbd} \\
20-100-30 \mathrm{cc} \\
20-101-27 \mathrm{cbc2} \\
22-105-7 \mathrm{aad} \\
25-106-27 \mathrm{ccd}\end{array}$ & $\begin{array}{r}40 \\
1,100 \\
697 \\
161 \\
152 \\
1,046 \\
166 \\
523 \\
99 \\
60 \\
\end{array}$ & $\begin{array}{l}\text { U } \\
\text { U } \\
H \\
S \\
U \\
U \\
U \\
U \\
S \\
I \\
\end{array}$ & $\begin{array}{ll}111 & \text { ALVL } \\
124 & \text { WSTC } \\
124 & \text { WSTC } \\
125 & \text { FRUN } \\
124 & \text { WSTC } \\
124 & \text { WSTC } \\
211 & \text { ALMD } \\
211 & \text { ERCS } \\
124 & \text { LNEY } \\
124 & \text { LNEY } \\
\end{array}$ & $\begin{array}{l}\text { WSE } \\
\text { WSE }\end{array}$ & $\begin{array}{l}1964- \\
1972- \\
1964-70 \\
1963- \\
1965-69 \\
1964-71 \\
1963- \\
1966-70 \\
1964- \\
1965- \\
\end{array}$ \\
\hline
\end{tabular}


Table 10.--Observation wells--continued

\begin{tabular}{|c|c|c|c|c|c|}
\hline $\begin{array}{l}\text { Well no. } \\
\text { and } \\
\text { location }\end{array}$ & $\begin{array}{l}\text { Wel1 } \\
\text { depth } \\
\text { (ft) }\end{array}$ & $\begin{array}{l}\text { Use of } \\
\text { water } \underline{\text { al }}\end{array}$ & $\begin{array}{l}\text { Geologic } \\
\text { source b/ }\end{array}$ & $\begin{array}{l}\text { Cooper- } \\
\text { ators } \mathrm{c} /\end{array}$ & Records available \\
\hline \multicolumn{6}{|c|}{ UINTA COUNTY } \\
\hline $\begin{array}{r}15-114-3 c b c \\
4 d a a 2 \\
10 c c c \\
15-115-20 c b a \\
21 c b d 2 \\
23 b d d \\
24 b a d \\
15-118-24 b c \\
16-114-27 d d d 2 \\
32 b c b \\
\end{array}$ & $\begin{array}{r}45 \\
25 \\
17 \\
17 \\
103 \\
5 \\
6 \\
80 \\
13 \\
12 \\
\end{array}$ & $\begin{array}{l}\mathrm{U} \\
\mathrm{U} \\
\mathrm{S} \\
\mathrm{U} \\
\mathrm{S} \\
\mathrm{U} \\
\mathrm{U} \\
\mathrm{U} \\
\mathrm{S} \\
\mathrm{U}\end{array}$ & $\begin{array}{ll}124 & \text { BRDG } \\
111 & \text { TRRC } \\
111 & \text { TRRC } \\
111 & \text { TRRC } \\
111 & \text { TRRC } \\
111 & \text { ALVL } \\
111 & \text { ALVL } \\
124 & \text { WSTC } \\
111 & \text { TRRC } \\
111 & \text { TRRC } \\
\end{array}$ & WSE & $\begin{array}{l}1957-69 \\
1957-62 \\
1957-64 \\
1957- \\
1957-64 \\
1957-64 \\
1957-69 \\
1964- \\
1957-69 \\
1957-62, \quad 1964 \\
\end{array}$ \\
\hline
\end{tabular}

al Use of water: H, domestic; I, irrigation; P, public supply;

$S$, stock; U, unused.

b/ Geologic source: 111 ALVL alluvial deposits

111 TRRC terrace deposits

124 BRDG Bridger Formation

124 LNEY Laney Shale Member of

Green River Formation

124 WSTC Wasatch Formation

125 FRUN Fort Union Formation

211 ALMD Almond Formation

211 ERCS Ericson Sandstone or Formation

c/ Cooperators: USGS U. S. Geological Survey.

WSE Wyoming State Engineer. 
Surface waters of the study area have been described previously in U.S. Bureau of Reclamation reports, Upper Colorado Region Framework reports, Wyoming State Planning reports, and U.S. Geological Survey publications. The more comprehensive reports are discussed below.

A comprehensive study of surface-water resources of the Upper Colorado River Basin, which included the Green River Basin in Wyoming, was made by Iorns, Hembree, and Oakland (1965). Their report discusses water quantity and quality and determines the effects of water use on streamflow.

The Wyoming Water Planning Program (1970) prepared a report on water and related land resources in the Green River and Great Divide Basins. The report presents an inventory of present water uses and future water needs. Several plans are presented in which alternative water-development facilities are proposed.

The U.S. Bureau of Reclamation (1972) prepared a special report on plans for development of water in the Green River Basin. A number of alternative plans are presented that could supply water needs for the next 50 years.

The Upper Colorado Region Comprehensive Framework Study (1970) and continuing studies on water quality by the U.S. Department of Interior (1975) include the Green River Basin in their discussions of water problems in the Colorado River Basin.

The ground-water supply has been described previously in Wyoming State Planning reports, and U.S. Geological Survey water-supply pap srs, hydrologic atlases, and a professional paper. These reports discuss ground water at a reconnalssance or descriptive level. Very little data have been gathered or analyzed about water supplies of deep aquifers.

Welder and McGreevy (1966), Welder (1968), and Lines and Glass (1973) describe results of water-resources investigations of large areas in Wyoming that include the study area. Their investigations were made with the purpose of locating potential water supplies for possible future development.

Data concerning ground-water and surface-water conditions in the East Fork River area were reported by O'Conne11 (1969), but no interpretation was made of the data.

A number of researchers have gathered and interpreted data from the Green River Basin to describe various hydrologic relations. Mrny of these studies are concerned with fluvial processes in geomorphology, as discussed by Leopold, Wolman, and M111er (1964). 
An evaluation of the general quality of game and fish resources and effects of water development on these resources was made by Binns (1972) for the Upper Green and New Fork Rivers.

\section{Water Demands and Uses}

Reports by the Wyoming Water Planning Program (1970) and by the U.S. Bureau of Reclamation (1972) provided the background information for the following discussion of water demands and uses.

Existing demands and uses.--Most of the water presently used in the study area is for irrigation. About 303,200 acres $\left(122,700 \mathrm{hm}^{2}\right.$ ) of land are presently being irrigated, and consumptive use of irrigation water is estimated to be 241,600 acre-ft $\left(297.9 \mathrm{hm}^{3}\right)$ per year. Irrigation water is obtained mainly from direct diversion of streamflows. Streamflow is largely the result of runoff from snowmelt, and flows generally diminish by the end of July. Most parts of the study area have inadequate reservoir storage to provide for late-season irrigation demands. Evaporation from reservoirs and stockponds amounts to about 26,000 acre-ft $\left(32 \mathrm{hm}^{3}\right)$ per year.

Industries, including two coal-fueled power plants and four trona processing plants, consume an estimated 30,000 acre-ft $\left(37 \mathrm{hm}^{3}\right)$ of water per year. Municipal water systems, serving about 40,000 persons in 17 communities, consume about 4,000 acre-ft $\left(4.9 \mathrm{hm}^{3}\right)$ per year. Domestic requirements consume about 2,000 acre-ft $\left(2.5 \mathrm{hm}^{3}\right)$ per year, and stockwater depletions amount to about 5,000 acre-ft $\left(6.2 \mathrm{hm}^{3}\right)$ per year.

Surface waters provide most of the above supplies; however, ground water is widely used for domestic and livestock purposes, and locally for municipal and industrial purposes.

Recreational activities, including fishing, hunting, boating, and camping are important nonconsumptive uses of water resources in tho area. About $2,520 \mathrm{mi}(4,050 \mathrm{~km})$ of streams and 70,000 surface acrss $\left(28,000 \mathrm{hm}^{2}\right)$ of lakes and impoundments provide cold-water fishery habitat in the basin. The area also supports some of the most varied and unique wildlife habitat in the United States. Excellent envir?nments exist for several big game species, including antelope, mule deer, $\mathrm{elk}$, and moose.

Future needs.--A review of proposed developments for the study area indicates that water needs will significantly increase. Table 11 lists present and projected water requirements for the various developments. 
Table 11.--Summary of present and projected consumptive water uses in the Green River and Great Divide Basins

[From Wyoming Water Planning Program, 1970, p. 110]

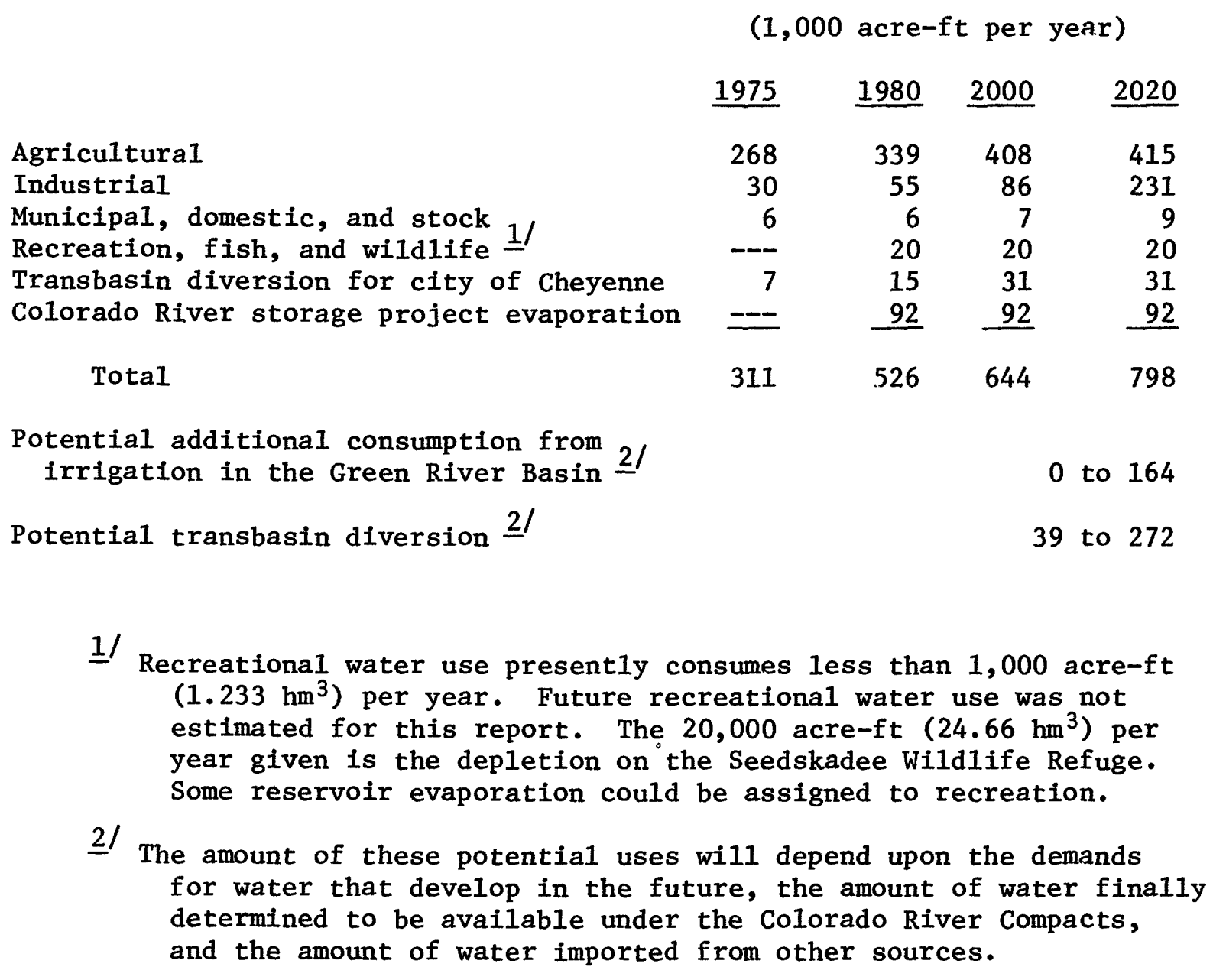


As economic development proceeds, large supplies of water will be needed at widely separated parts of the basins for recovery and utilization of the resources, for municipal supplies, and for recreation. Although surface-water resources are adequate for projected demands, the distribution of demands does not coincide with the distribution of supplies. Economic and environmental considerations may make grountwater supplies more attractive than surface-water supplies. Thus, water supplies may be developed from ground-water sources and from small watersheds near the coal and oil-shale deposits. Some supplies will likely be transferred from one part of the area to other areas within the basins and, possibly, to other water-short areas in the State.

Several methods of developing surface-water supplies in the st'dy area have been proposed by the U.S. Bureau of Reclamation (1972, p. IV-1 to IV-29) and the Wyoming Water Planning Program (1970, p. 115-154). Figure 23 shows locations of these potential water-supply developments. Several reservoir sites exist that could provide water for the study area, as well as for transbasin diversion to the Platte and Powder River basins.

Very important to the development of surface waters in the Grean River Basin are the compact agreements for the Colorado River system. The Colorado River Compact of 1922 and the Upper Colorado River Basin Compact of 1948 apportion the use of waters from the Colorado River system among the seven states involved. Due to differences of interpretation of certain Compact provisions, the amounts of water allocated to individual states are not clear. Depending on the interpretation of the Compact, allocation of water for Wyoming may be as little as 875,00 ) acre-ft $\left(1,080 \mathrm{hm}^{3}\right)$ per year, or as much as $1,043,000$ acre-ft $\left(1,286 \mathrm{hm}^{3}\right)$ per year.

The development of ground waters has not been investigated as thorough1y as surface waters. There is concern that extensive groundwater development would decrease streamflows, and thereby affect surfacewater rights from streams. Deep ground water might be developed in the sedimentary rocks in the northern part of the study area; however, additional data and study are needed to determine water resources of the deep aquifers. 


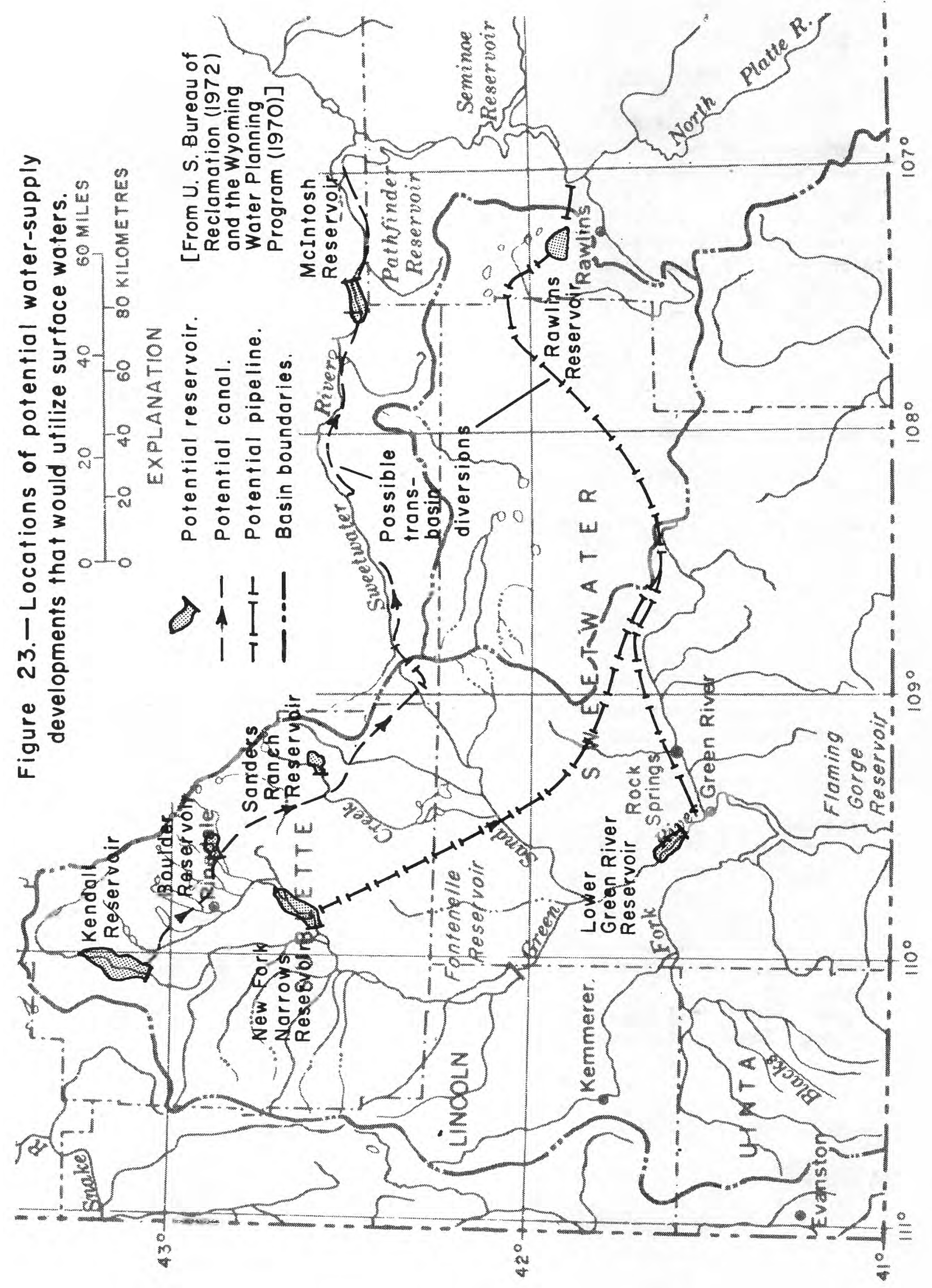




\section{DESCRIPTION OF THE STUDY PLAN}

This section of the report presents a description of the procedures, techniques, and methodologies to be used in fulfilling the project objectives. The overall plan of the study is to determine important hydrologic variables, and to define interxelations that exist between these and other variables. In general, the study would be directed towards providing an overall view of the water and water-related resources in the project area. However, intensive studies would be made at Energy Mineral Rehabilitation Inventory and Analysis (EMRIA) sites, and at a few areas where energy development is already taking place. These intensive studies would be made to determine hydrologic effects of energy development so that a better understanding of these effects will be available for planning of future developments. The EMRIA study sites are under the dixection of the U.S. Bureau of Land Management and involve rehabilitation studies of oil shale and coal strip-mine areas.

The study plan would remain flexible so that it can be modified to fit the particular needs of other Federal, State, and local agencies. The study plan is tentative, and can be changed to fit budgetary, personnel, and travel restrictions, if they occur.

\section{Surface Water}

\section{Streamflow}

A review of surface-water data needs reveals that 35 new gaging stations should be installed on streams in the study area. Many of the new gages should be installed in the plains areas, as 1ittle data presently exist for runoff of ephemeral and intermittent streams. Figure 24 shows approximate locations of the proposed stations. Fifteen continuous-record stations and 20 partial-record stations are proposed for new operation. Selection of the gaged sites was made with both streamflow and quality-of-water data needs in mind.

The operation of the new partial-record stations would be provided for by project funds of the U.S. Geological Survey. The U.S. Bureau of Land Management is providing funds for operation of six of the continuousrecord stations. The remaining nine continuous-record stations would require additional funding; it is hoped that this will be provided for by other Federal and State agencies. 


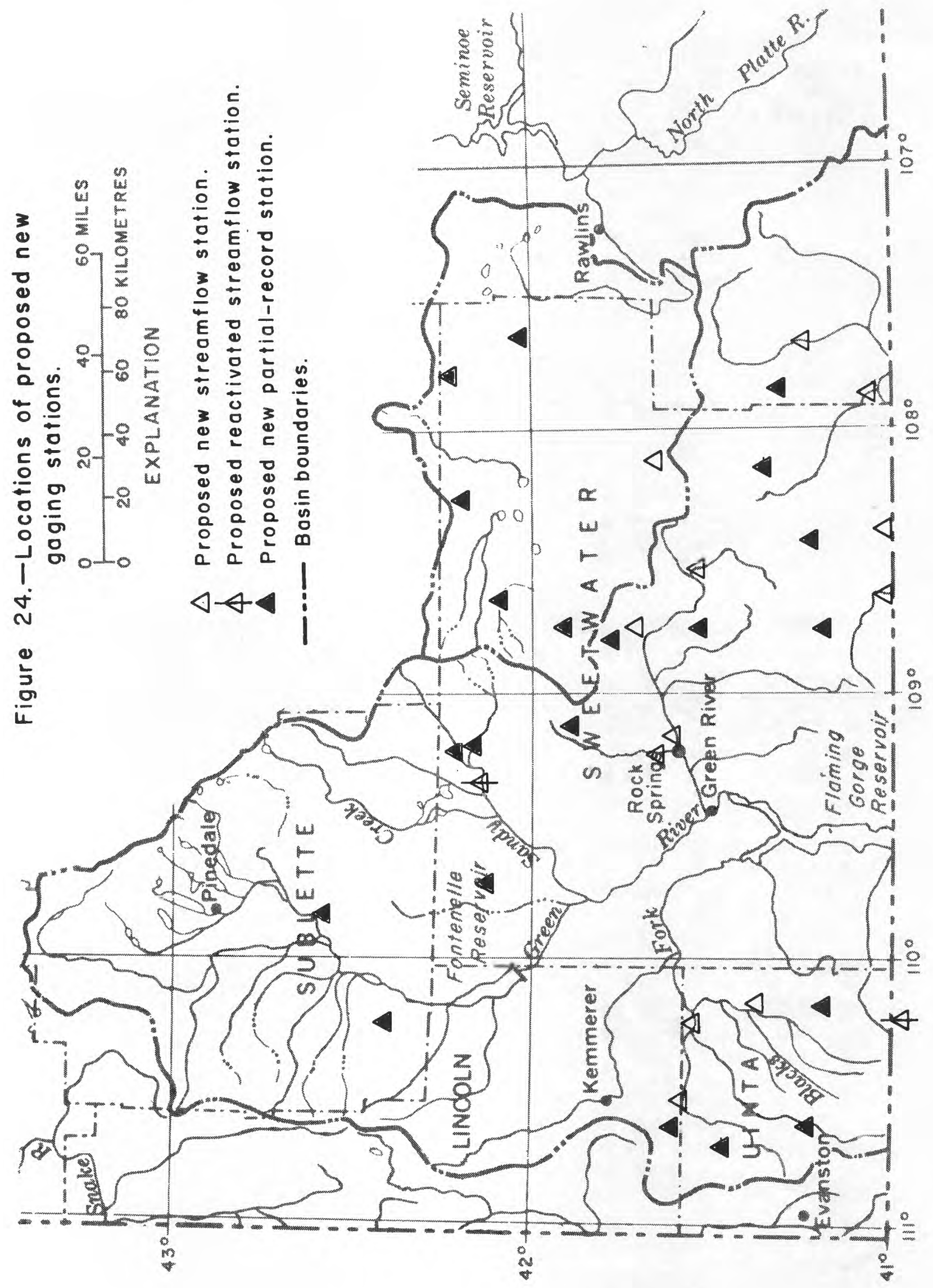


In addition to streamflow records, data would also be obtained from measurements of related variables, which will include:

1. Base-flow (seepage) measurements along selected streams. These measurements would help identify surface waterground water relations.

2. Traveltime and dispersion measurements of main streams. These measurements would be used to identify hydraulic characteristics of the streams in the area, and also would be used to help develop a water-quality solute model (discussed more fully in a later section).

3. Measurements of basin characteristics from maps and field surveys to determine cause-effect relations that exist between basin and streamflow characteristics.

4. Field measurements of channel dimensions, and measurements of streambed material along selected streams to determine relations that exist between channels and their flows. The investigation of channel characteristics is discussed more fully in a later section of the report.

Existing and new surface-water data would be analyzed to determine streamflow characteristics at gaged sites, and to develop improved relations for estimating these characteristics at ungaged sites. Statistical analyses would be made to determine potential water supply, and to determine the relation of surface waters to other aspects of the hydrologic environment. The statistical methods will include trend analyses, probability studies, and correlation analyses.

A streamflow routing model would be tested by personnel of the U.S. Geological Survey on data gathered from a reach of the East Fork River during the spring of 1975. The model is a recent development of James P. Bennett (written commun., 1975) and is being tested as part of a research project in collaboration with William W. Emmett, Carl F. Nordin, and Robert H. Meade. Their plan is to test the usefulness and applicability of the model in routing streamflows, as well as for the determination of total sediment load. If the model proves to be applicable, it could provide the basis for streamflow and water-quality modeling of streams throughout the study area. 
Specific conductance, salinity, and discharge data would be used to determine functional relations, which would be used to describe the chemical quality of surface waters. For example, figure 25 shows the seasonal variation of discharge, dissolved-solids concentration, and dissolved-solids load at station 09188500 Green River at Warren Bridge, near Danie1, Wyoming. The dissolved-solids concentrations and loads at this station were simulated through the use of a functional relation between total-dissolved solids concentration and discharge. Figure 26 shows the relation of daily specific conductance to daily discharge at station 09217000 Green River near Green River, Wyoming for the 1972 water year. This relation was developed through the use of a simple two-variable regression model (Steele, 1970). Refinement of such regression equations ${ }^{1}$ to include seasonal effects, stage gradient, antecedent conditions, or areal variations would be investigated to improve sensitivity of these relations in detecting trends in water quality and their related causes. For example, the hysteresis apparent in figure 26 might be attributed to one or more of the variables mentioned before. Time dependence of this effect is shown in figure 27. Measurement of specific conductance with all discharge measurements would be initiated to increase areal coverage of salinity data with a minimal increase in the data-collection effort. Additional stations, shown necessary by analysis of the data, would be established to identify major sources of salinity and possible changes resulting from development. Special emphasis would be placed on ephemeral and intermittent streams.

Mathematical models would be investigated as an ald in predicting salinity in the Green River and its major tributaries. Stresses imposed on the model(s) would include construction and operation of new reservoirs, diversions, increased irrigation, discharge of wastes, and shallow groundwater development. Because it is necessary that the stresses be applied and effects simulated both above and below Fontenelle Reservoir, a mathematical model may also be required.for the reservoir.

Chemical-quality data, other than salinity, are virtually nonexistent in the study area. Preliminary data concerning trace elements, radioactive elements, and organics would be collected at selected waterquality stations. Variables to be measured and frequency of sampling would be determined from this reconnaissance in order to efficiently allocate the data-collection effort.

$1 A Q=K$ or $A+B K=C$; where $A$ and $B$ are regression coefficients, $\mathrm{Q}=$ discharge, $\mathrm{C}=$ constituent concentration, and $\mathrm{K}=$ specific conductance at $25^{\circ} \mathrm{C}$. 
$\wedge \forall O \forall \exists d$ S

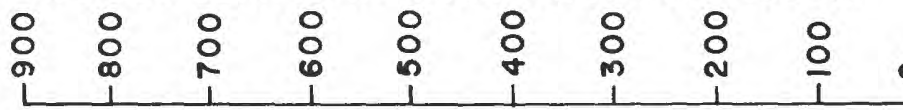

ONOJ

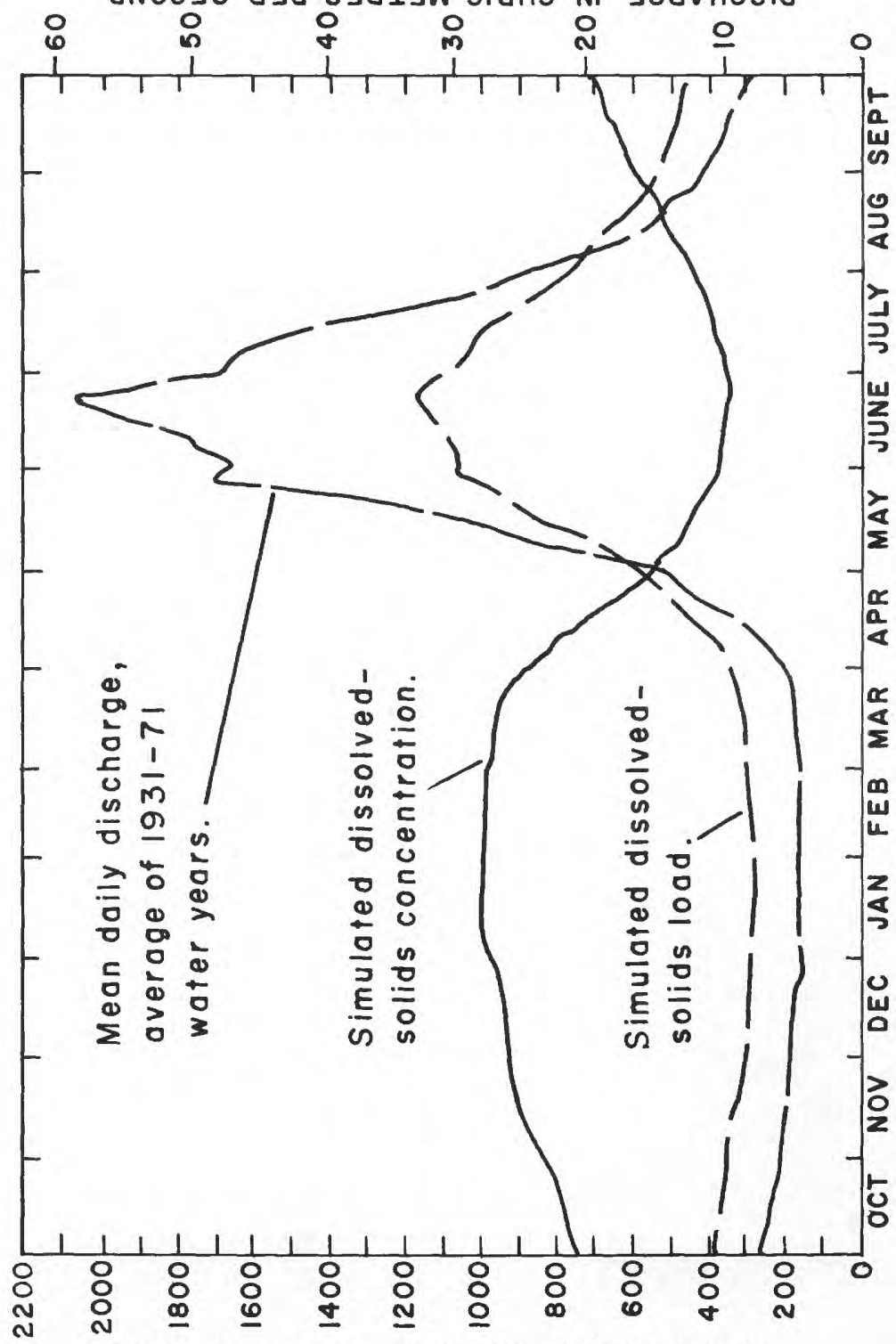

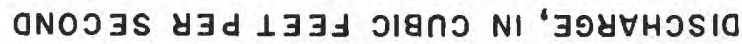

\begin{tabular}{lllllllllll}
\hline & 1 & 1 & 1 & 1 & 1 & 1 & 1 \\
0 & 0 & 8 & 0 & 0 & 0 & 0 & 0 & 0 \\
0 & 0 & 0 & 0 & 0 & 8 & 0 & 0
\end{tabular}

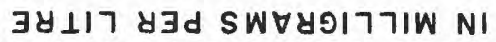

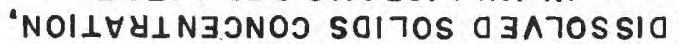

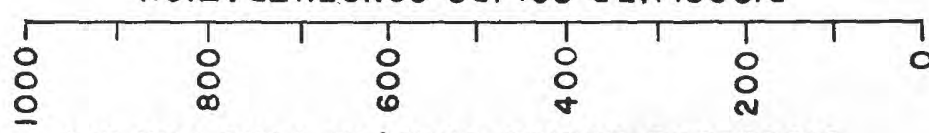

$\stackrel{0}{0}$

थ

- $\frac{E}{E}$

$\stackrel{0}{\geq}$

운 3

$\frac{n}{0} \div$

읃

○ 0

ㄷํㅇ రั

$\div c$

¿

e. 으

它

0

인

으은

í

응

ํㅣㅇ

a

$\frac{1}{0}$

i

on

$\div 0$

ㄴ.

is 0

ชั

$\geq \infty$

응

등드

$\sum$

$1 \div$

กั ธ

농응

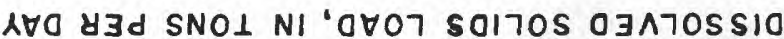




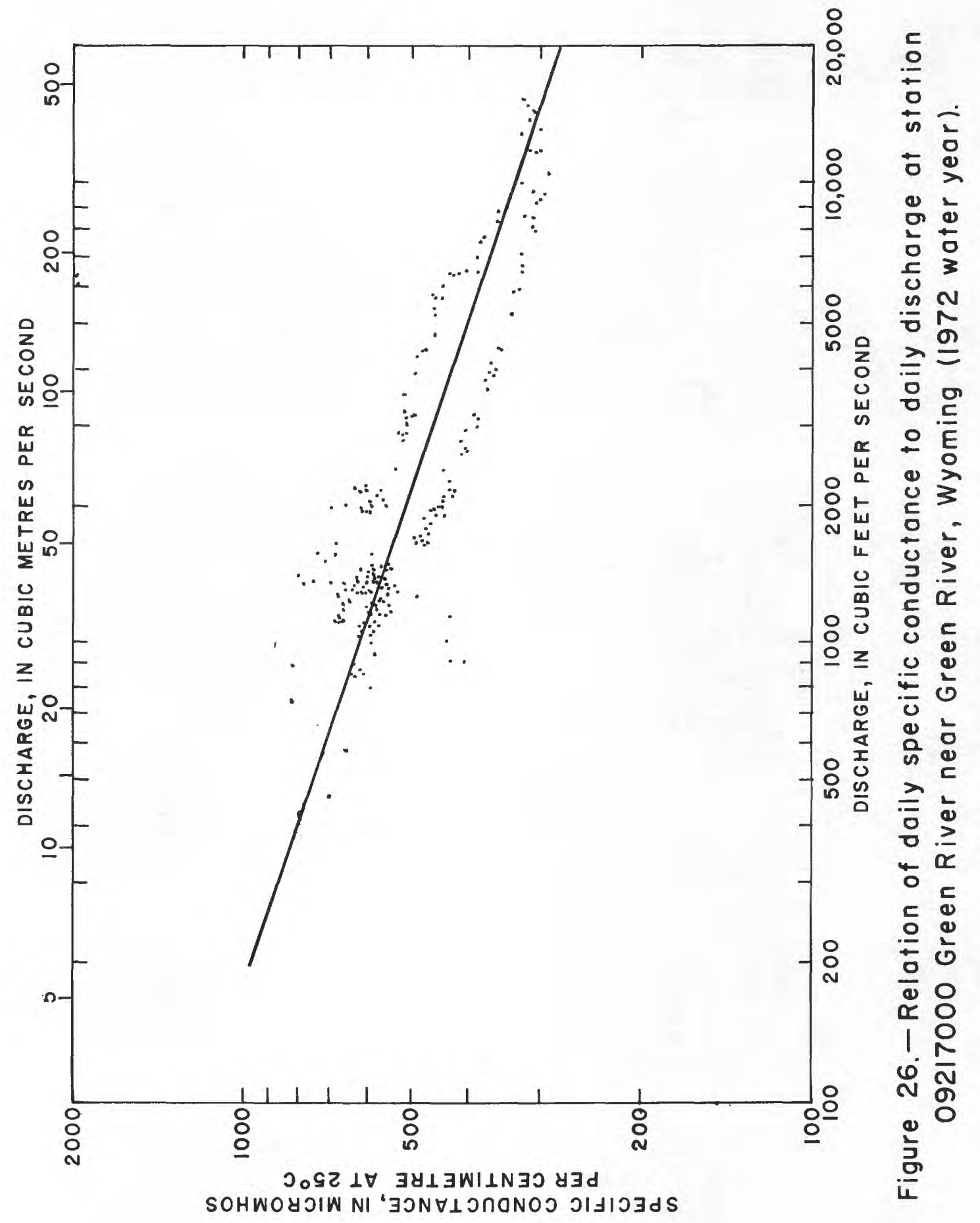




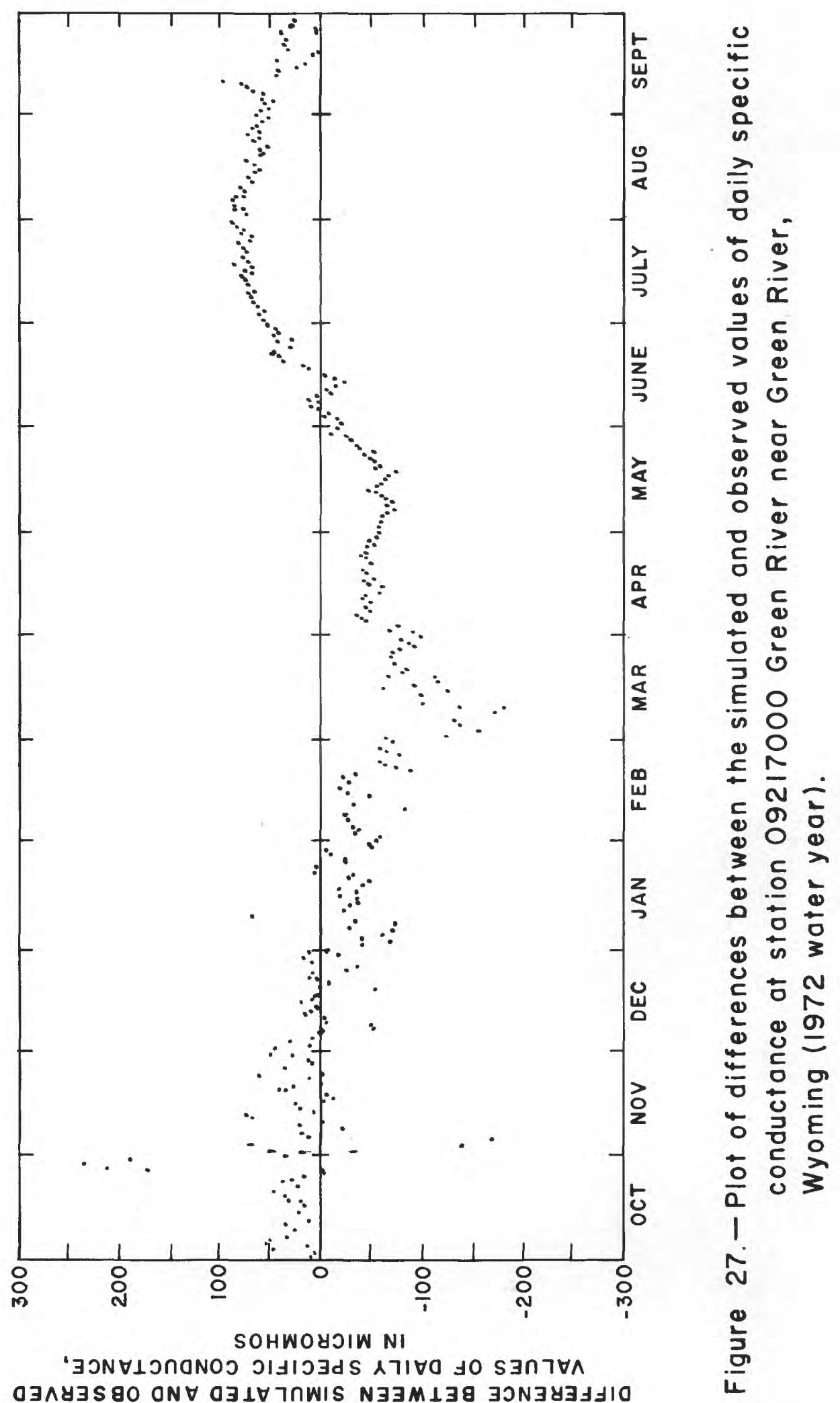




\section{Biological Quality}

Water users and planners are becoming increasingly aware of the relation between the biologic community and the qualitative and physical characteristics of surface water. Aquatic organisms respond continually to the environment, and reflect in their numbers and kinds the interactions of chemical, physical, and biological factors. Changing land use and industrial development can significantly affect aquatic biology. With proper understanding of these relations, water developments can often be planned in such a way as to improve, rather than degrade, the environment.

Existing information concerning the aquatic biology of the study area is limited. Previous studies have been concerned primarily with fish and only passing reference has been made to benthic organisms and plankton as a source of fish food.

Increased data-collection activity would be implemented during the first year of the study. Nine water-quality stations have been selected for biological assessment. (See fig. 28.) Samples at each station would be collected in such a way as to represent total populations of the stream reach. In addition, periodic samples would be obtained on major lakes and reservoirs of the area to determine baseline conditions. Random samples of other streams and lakes would be collected to supplement data obtained at the regular stations and to define areal variability.

A11 members of an aquatic community should be defined in a biological study. Limitations in time and money would generally restrict the study to a monthly sampling schedule that would include bacteria, fish, plankton, periphyton, macroinvertebrates, macrophytes, and algal growth potential.

A preliminary analysis of the data would be made after the first year of data collection. Biologic variables would be related to chemical and physical variables, and to each other. A speciesdiversity index would be determined at each sampling site.

\section{Temperature}

Water temperatures are important to many water users. They are important to the sportsman, as they are a vital factor affecting fish 1ife. They are important to agricultural users, as temperature of irrigation water can affect crop production. Industrial water users often utilize water for cooling purposes, and must consider temperature in plant design and operation. The physical, chemical, and biological properties of water are closely related to temperature as it affects sediment transport, rates of chemical reactions, and biological processes. As part of the study, a compilation of periodic water-temperature data at streamflow stations has been made (Lowham, Kircher, and Boner, 1975 ). 


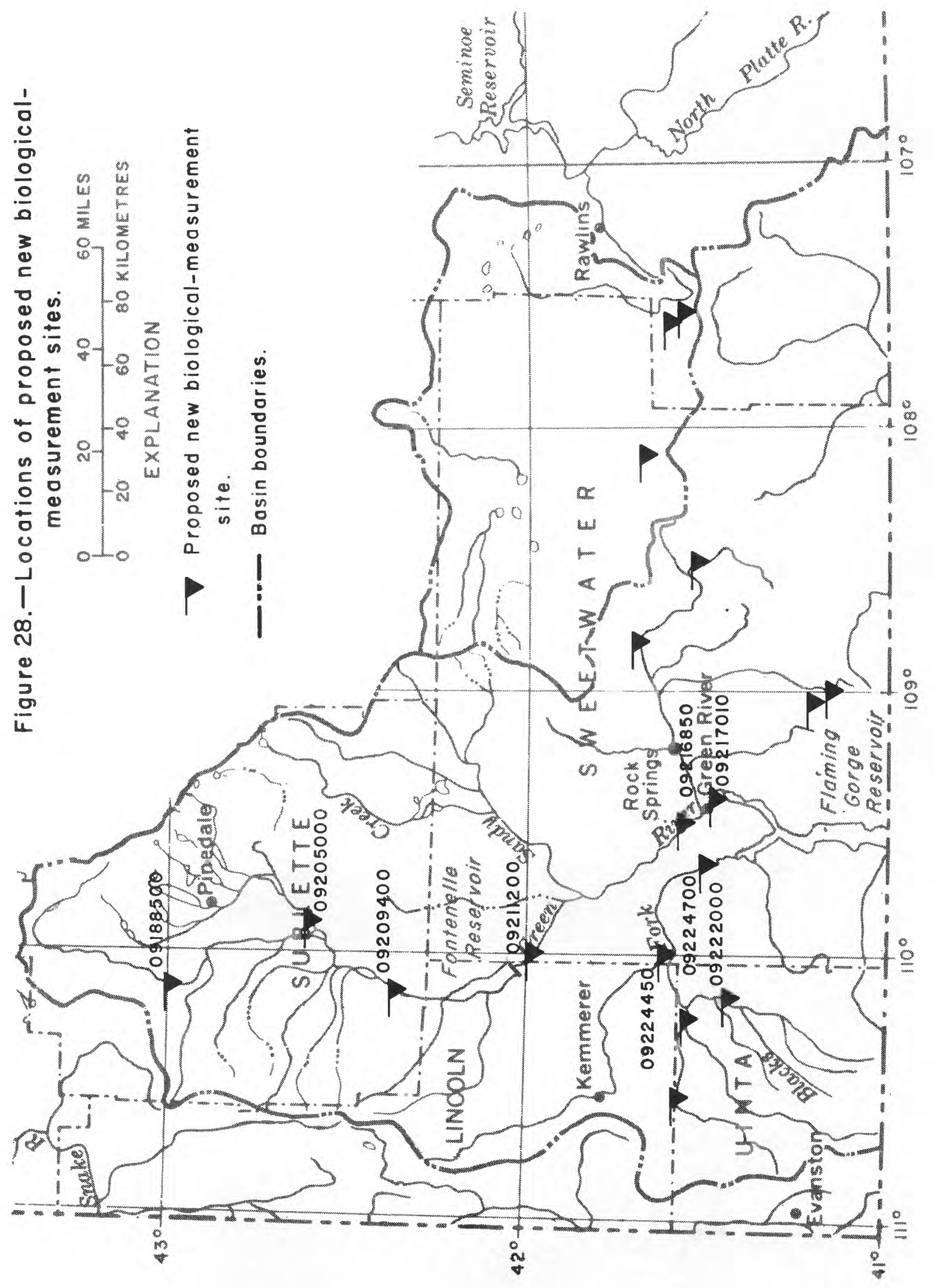


An analysis would be made to determine stream-temperature characteristics on a regional basis. Continuous and periodic water-temperature data would be analyzed by using a simple harmonic curve-fitting procedure (Steele, 1974, p. 1-6). Regional values of the harmonic coefficients would then be analyzed by regression with basin and climatic variables. Results of the analyses would be published along with typical examples (case studies) so that the relations determined may be helpful to water managers in making their decisions and plans.

\section{Sediment}

Sediment is an important factor of water quality in the study area. Sediment concentration can affect the use of water and design of structures. Sediment also affects turbidity, which is important to aesthetic value and certain biological relations.

A study of available data concerning sediment reveals that much additional data is needed, particularly for the smaller streams. Datacollection activities have thus been expanded to include the collection of suspended-sediment samples at all continuous- and partial-record gaging stations whenever discharge measurements are made. In addition, single-stage samplers have been installed at all gage sites on ephemeral and intermittent streams.

Many variables affect sediment discharge, and no simple method exists for accurately describing sediment concentrations or yields for an area of diverse physiographic and hydrologic conditions; however, approximate relations can be developed that would serve the purposes of most users. For example, figure 29 shows the relation of suspendedsediment concentration versus discharge at station 09213500 Big Sandy River near Farson, Wyoming. Similar relations would be developed for all continuous-and partial-record gaged sites, and a sediment-yield map would be prepared with the aid of these relations.

Supply of sediment to a stream is largely dependent upon erosion of the drainage-basin surface. Rates of erosion would be determined by establishing reference marks and periodically surveying grid sections at several locations throughout the study area. These data would aid in defining sediment yields.

Research on bedload transport has been done on the East Fork River near Pinedale (Leopold, L. B., and Emmett, W. W., 1976) for about the past 10 years. Data collected for these research activities will provide useful information concerning bedload transport of the streams of the area. 


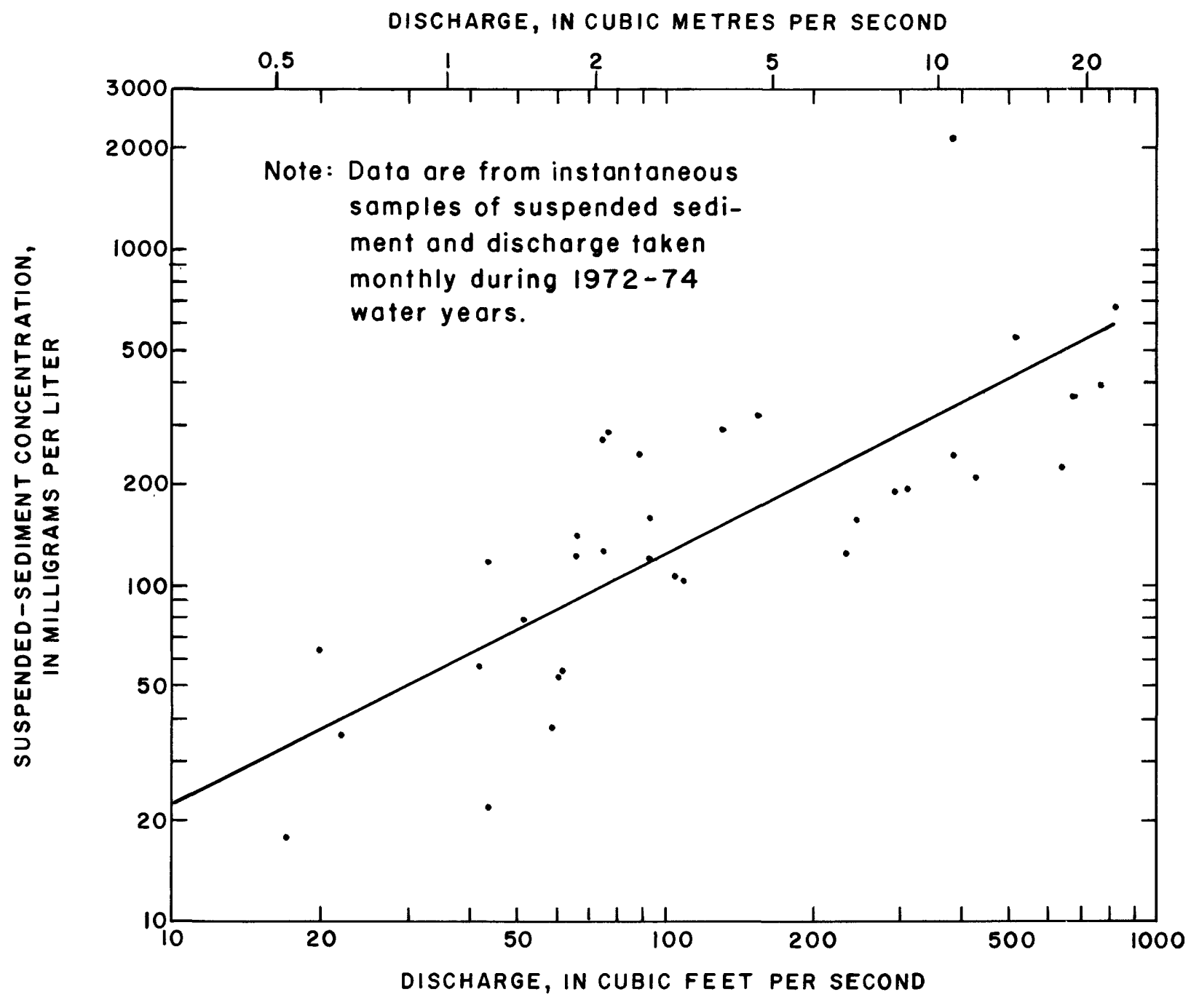

Figure 29.-Relation of suspended-sediment concentration to discharge at station 09213500 Big Sandy River near Farson, Wyoming. 


\section{Channel Characteristics}

The physical characteristics of a stream channel are highly related to its flow and sediment discharge. Depending on the flow regime and available sediment load, a stream naturally strives toward a state of equilibrium by aggrading or degrading. Many aspects of the environment, such as aquatic biology, are in turn dependent upon the physical characteristics of the stream channel. Thus, a change in the flow regime or sediment discharge will result in changes to the physical characteristics of the channel, which can in turn affect certain aspects of plant and animal life.

Man's activities may produce major changes in a stream both locally and along a reach of channel. Proper planning of developments requires an understanding of the basic relations that exist between streamflow variables and other aspects of the environment.

The hydraulic properties of the streams of the area would be defined in a manner similar to studies conducted by Leopold and Maddock (1953), and Emmett (1972, 1975). Data obtained at gaging stations would be used to define the hydraulic characteristics at the gaged sites. These characteristics would then be used to develop regional relations so that hydraulic characteristics at ungaged sites may be inferred. Relations of width, mean depth, mean velocity, and flow area as functions of discharge have already been defined for 42 gaged sites in the study area. Figure 30 is a typical example of these relations, showing changes in width, mean depth, and mean velocity with discharge at station 09205500 North Piney Creek near Mason.

Regional relations, which utilize the hydraulic characteristics defined at the 42 gaged sites, have been developed to compare hydraulic characteristics of streams throughout the study area. It is planned to gather additional data to further refine these relations; however, preliminary examples of the regional relations are shown in figure 31 .

The relations shown in figures 30 and 31 utilized data from currentmeter discharge measurements made at the gaged sites. Discharge measurements are generally made at various sections of a stream reach near the gage. Prior to measuring, the hydrographer selects a good measuring section for the particular discharge and does not choose the same section each time. The hydraulic data thus contain some inconsistencies due to variabilities inherent to the measurement process. More consistent relations could be developed if the data were derived fron a particular cross section of the stream. Data of this type would be obtained for this part of the study. 
DISCHARGE, IN CUBIC METRES PER SECOND
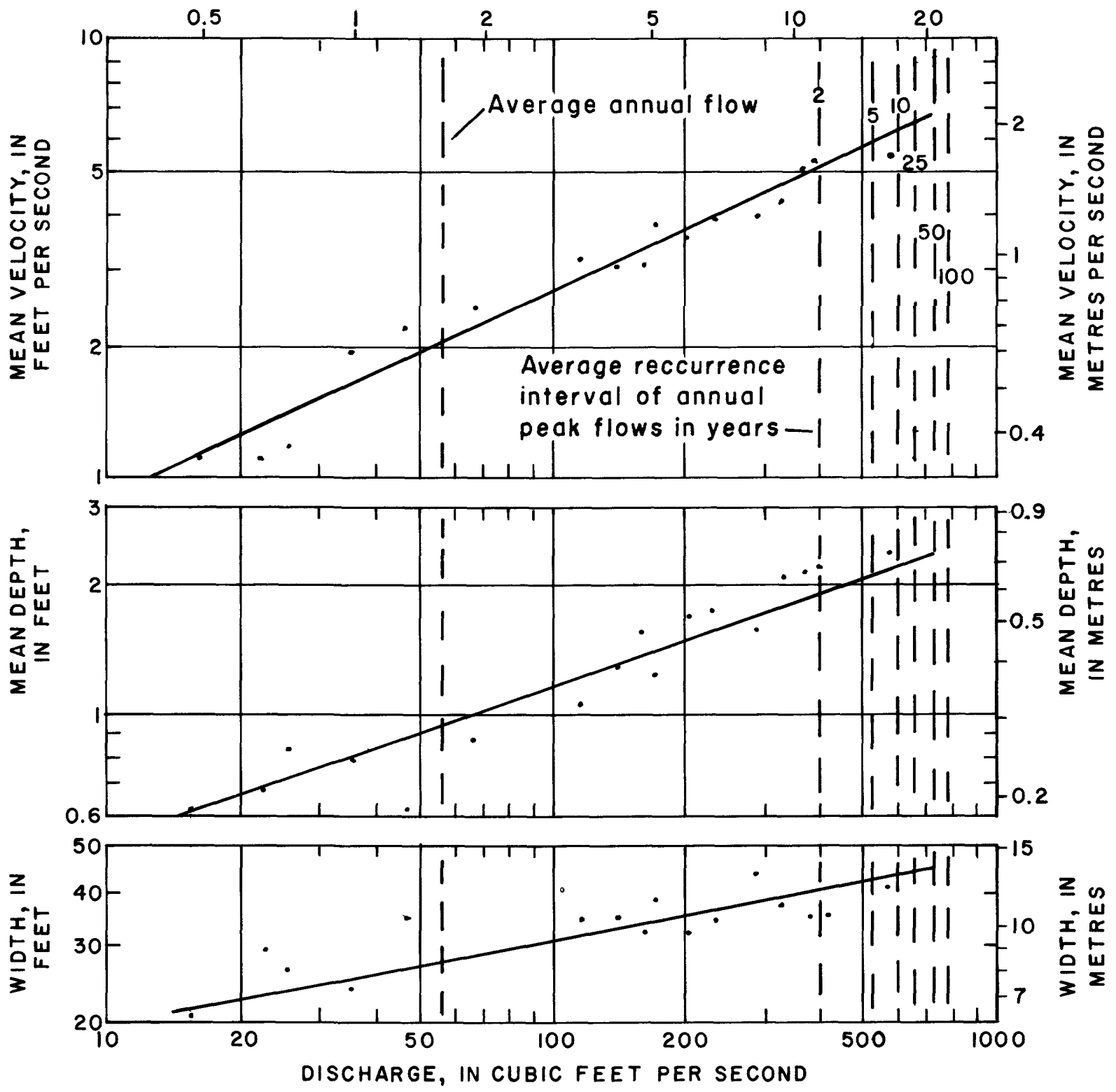

Figure 30.-Changes of width, mean depth, and mean velocity with discharge of a channel cross section, station 09205500 North Piney Creek near Mason, Wyoming. 
TWO-YEAR PEAK DISCHARGE, IN CUBIC METRES PER SECOND
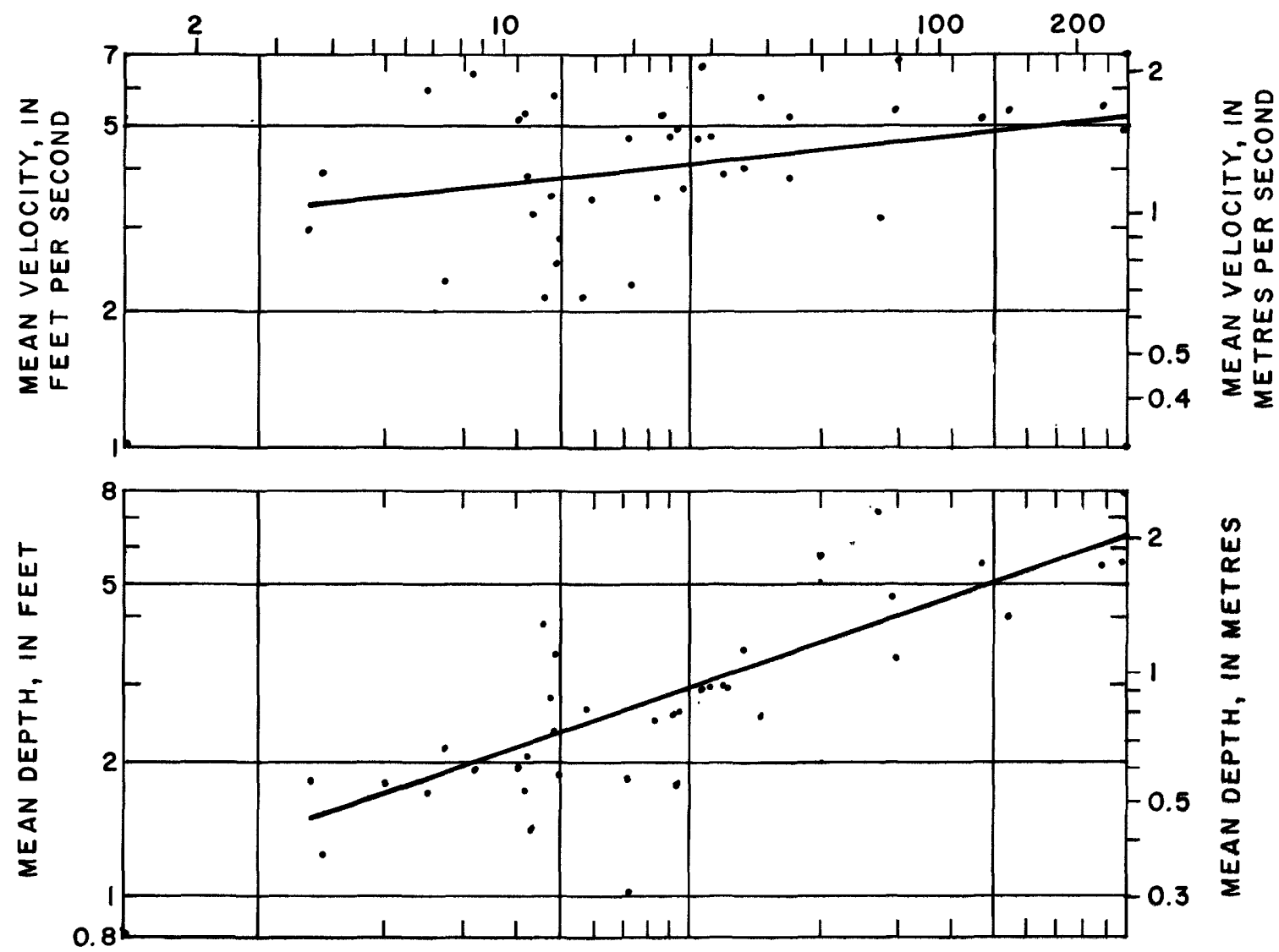

H.

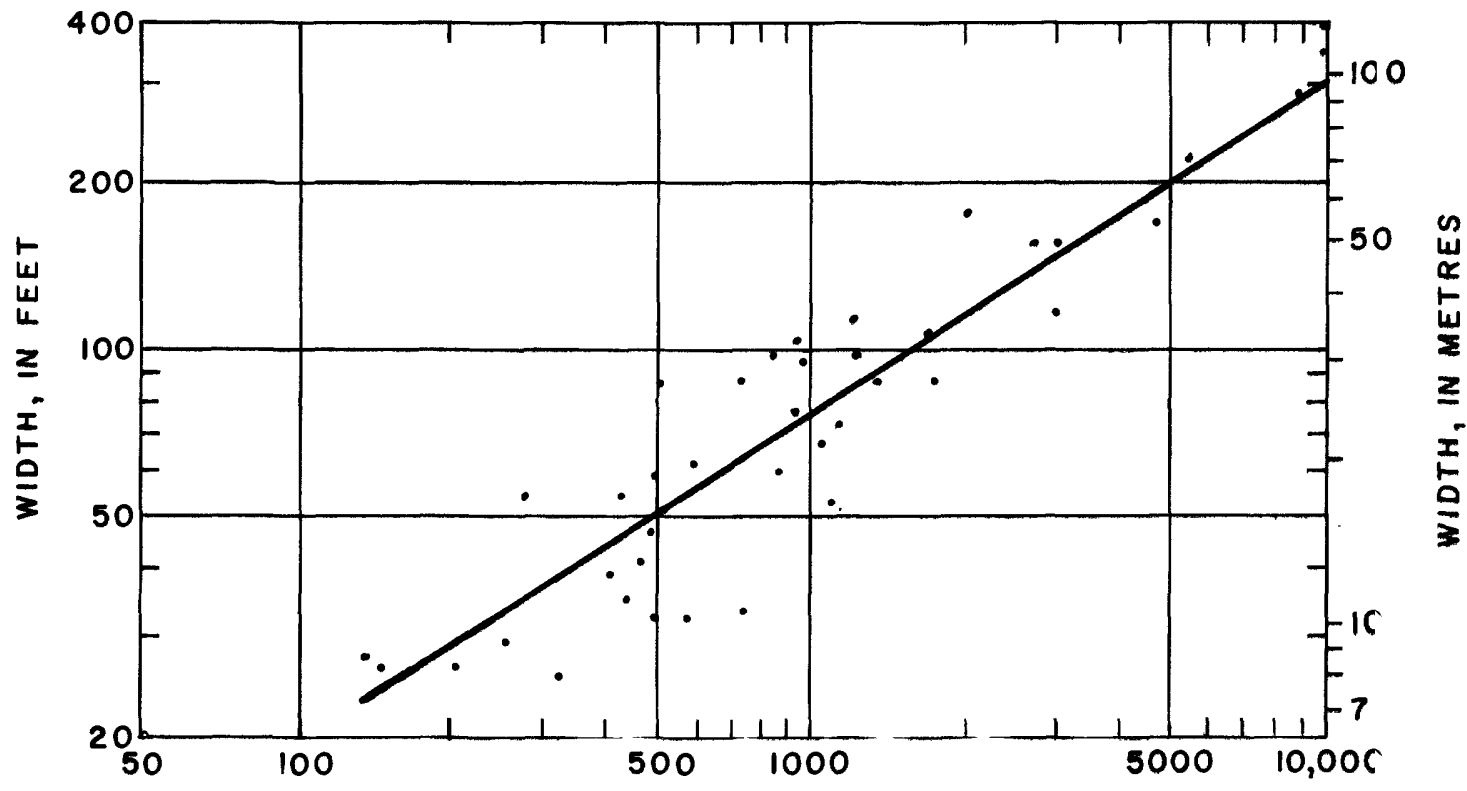

TWO-YEAR PEAK DISCHARGE, IN CUBIC FEET PER SECOND

Figure 31.-Stream width, mean depth, and mean velocity in relation to 2-year peak discharge os discharge increases downstream, Green River ond tributaries, Wyoming. 
Because the physical properties of a channel are representative indices of the prevailing streamflow and sediment discharge, the establishment of a number of cross sections on stream channels throughout the study area is an excellent way to determine baseline conditions and to detect changes in these conditions. Several cross sections have alr?ady been surveyed, and reference marks were established so that subsequent surveys may be made to detect possible changes or trends in the hydrologic environment. Figure 32 shows the results of one such survey made on Delaney Draw near Red Desert. This is an ephemeral stream whose channel has recently downcut as a result of changes in its upstream drainage. Subsequent surveys of the cross section will help determine whether the stream has reached a new equilibrium profile, or whether some changes are still occurring.

Data concerning other channel characteristics such as slope, sinuosity, and bed material would also be collected and related to the hydrologic environment. It is planned to conduct a number of surveys along selected streams to determine relations in respect to increasing discharge in the downstream direction, and in particular to determine the effects of surface geology and land use on these relations.

\section{Ground Water}

\section{Determination of Potential Supply}

As developments proceed, large supplies of water will be needed at widely separated parts of the study area for recovery and utilization of the resources, for municipal supplies, and for recreation. Althougt present surface-water resources are adequate in quantity, distribution in space and time do not fit projected demands. Economic and envirc nmental considerations may make ground-water supplies more attractive than surface-water supplies. Thus, as often happens in a developing aree, attention is focused on the potential of ground water to supply the new water demands. Ground water in the study ${ }^{\circ}$ area is relatively undevejoped and very little quantitative information is available on this resource.

The evaluation of a potentlal ground-water supply requires date. concerning both the chemical quality and yield of underlying aquifers. Particular uses of water have certain standards; for example, grounc water from a particular aquifer could have fluoride concentrations that would prohibit its use for domestic purposes, but it could still be used for many industrial purposes. An aquifer may not have the capability to yield large supplies of water for a long period of time without the ground-water level being serlously lowered, but it may yield small supplies of good quality water for domestic use. Information on both chemical quality and water availability is thus very important in planning ground-water development, and the study would be directed towards determining these items. 


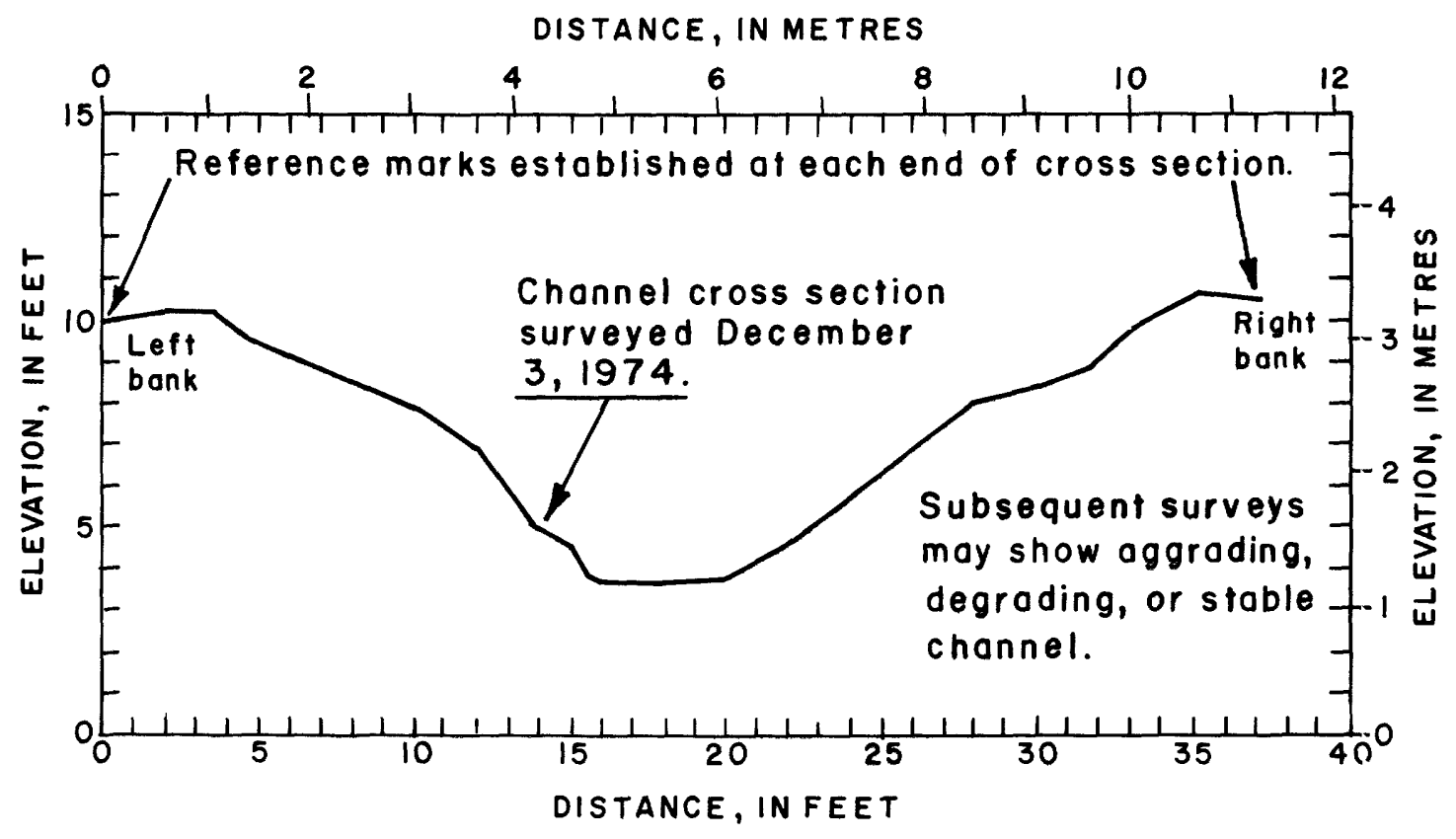

Figure 32.-Cross section of Delaney Draw near Red Desert, Wyoming. 
Emphasis of study would be on aquifers of Holocene, Tertiary, and Late Cretaceous ages. (See fig. 3.) The formations with the greatest ground-water potential are gravel deposits near the Wind River Range, some alluvial deposits, the North Park(?) Formation, the South Pass Formation, the Browns Park Formation, the Pass Peak Conglomerate, the Battle Spring Formation, the Green River Formation, the Wasatch Formation, the Fort Union Formation, the Ericson Formation, and the Rock Springs Formation (Welder, 1968; and Welder and McGreevy, 1966). Some of these aquifers, such as the North Park(?) Formation along the eastern edge of the study area, are very limited in extent. Also, some of the formations have good ground-water potential in some, but not all, of their members. For example, the ground-water potential of the Laney and Tipton Shale Members of the Green River Formation is good, but the potential is poor for the Wilkins Peak Member.

First efforts of the study would be directed toward compiling and evaluating data that are already available. These data would be obtained from basic-data reports (Ringen, 1973, 1974) and from a well inventory conducted during the early part of the project. Records of chemical analyses of water and yields of wells would be compiled for each aquifer studied. Water samples would be analyzed for common chemical constituents, trace elements, and radiochemicals.

To quantitatively evaluate aquifer characteristics such as transmissivity and storage coefficient, aquifer tests would be conducted wherever practical. Numerous test methods may be used such as reccrery, slug, bailer, constant discharge, constant drawdown, and specific capacity methods. The method used would depend on the condition of the well, the availability of observation wells, and knowledge of the geology and hydrology of the aquifer. Specific capacities would be. used for estimating transmissivities if the wells are known to be properly constructed. Lithologic logs, the results of drill-stem tests perf ormed by industry, and geophysical logs would provide supplementary data on aquifer characteristics.

Water levels would be measured in a11 avallable we1ls. Where more long-term information is needed, observation wells would be installed. Chemical analyses would be compiled and, if sufficient data exist, maps would be prepared that show how chemical quality varies areally and vertically in different aquifers. Water-level measurements would to used for drawing potentiometric maps. Potentiometric-surface maps, used with topographic and structure maps, would show direction of grouncwater movement, depth to water, and saturated thicknesses. In arees of development, water-level measurements may be used to draw water-lerel change maps. Water-level hydrographs may also be drawn to illustrate normal variability or regional trends. Maps of transmissivity would be drawn where possible. Storage coefficients and transmissivities calculated from aquifer tests would be used with chemical analyses to describe the potential of the aquifers as sources of ground water. 


\section{Effects of Economic Development}

As economic development accelerates in the study area, ground water may be affected in many complex ways. If ground-water withdrawals exceed recharge, water levels will decline. If leakage between saline and non-saline aquifers is increased, water quality will change. Mining activities, waterflooding in oil and gas fields, and oil-stale retorting could affect the ground-water system.

Because of the large size of the study area, this work would begin with a reconnaissance of areas of potential impact. This would irmlude examination of development in mining areas and oil and gas fields. Both active and abandoned sites would be studied. In addition, tro reconnaissance phase would evaluate areas most likely to have oil-shale development. A system for gathering background data and monitorirs effects of future oil-shale development would be established.

Intensive study would take place at the EMRIA (Energy Minera] Rehabilitation Inventory and Analysis) sites and at other sites whore development may take place.

In coal mining areas, the ground-water conditions would be eramined at a reconnaissance level, with more intensive study as needed. Study would be oriented towards such activities as mine dewatering, spoj.1 banks, flooding in abandoned mines, and current and planned reclanation.

Underground trona mines have had flooding problems with grourt water from the Tipton Shale Member of the Green River Formation. The trona-bearing rocks in the Wilkins Peak Member of the Green River Formation overlie the Tipton Shale Member. The steps that industry has taken to relieve this problem would be studied. This information would be important because the oil shale that may be developed in this ares is in the same formation members.

Waterflooding as part of oil and gas production may affect groundwater chemistry and supply. A reconnaissance study of available company records would be used to evaluate areas where more intensive study may be needed. Particular attention would be given to the aquifer characteristics, the chemical quality of water, and the potentiometric surfaces of both the source aquifer and the injected unit.

Currently (1976), there are no oil-shale leases in Wyoming. The study of the relation between ground water and oil-shale development would be at a reconnaissance level. An important part of the study would involve obtaining background data on current ground-water conditions in areas of potential oil-shale development. Data coljection would be intensified in areas where development is planned. 


\section{Well and Spring Inventory}

Except for a small part of the study area investigated by Lines and Glass (1973), there has been no inventory of the wells and springs in the area since those done by Welder (1968) and Welder and McGreevy (1966). Many wells have since been developed.

A well and spring inventory would be made during the first few years of the project. A record of all registered wells would be obtained from the Wyoming State Engineer's office. Requests would be made to industry and local landowners for information on additional wells that have been drilled recently.

Observation wells would be selected from the well inventory in areas where aquifer tests and water-quality samples are needed. Wells would also be selected along major streams for use in studying surfaceand ground-water interrelations.

\section{Borehole Geophysics}

Techniques of borehole geophysics including geophysical well logs, temperature logs, and vertical seismic profiling, can provide valuable information about ground-water resources. Oil companies have used these techniques extensively in the study area; however, they have not been previously used for water-resource investigations.

Geophysical logs can provide information concerning primary and secondary porosities, rock density, rock velocity, thickness, and structure. For example, figure 33 shows results of geophysical logs cross correlated by computer analysis for porosity and 1ithology. Temperature data can be interpreted to show ground-water movement and anomalies reflecting aquifer characteristics. Vertical seismic profiles can be correlated with surface seismic data to extend borehole information on lithology, porosity, and fluid content. Geophysical logs would be obtained at all new test holes and observation wells drilled as part of the project study. Temperature data would be collected from commercial logging sources and through new logging.

\section{Surface Geophysics}

Surface geophysical methods, including resistivity, gravity, and seismic measurements, can provide efficient and inexpensive exploration of shallow aquifers. 


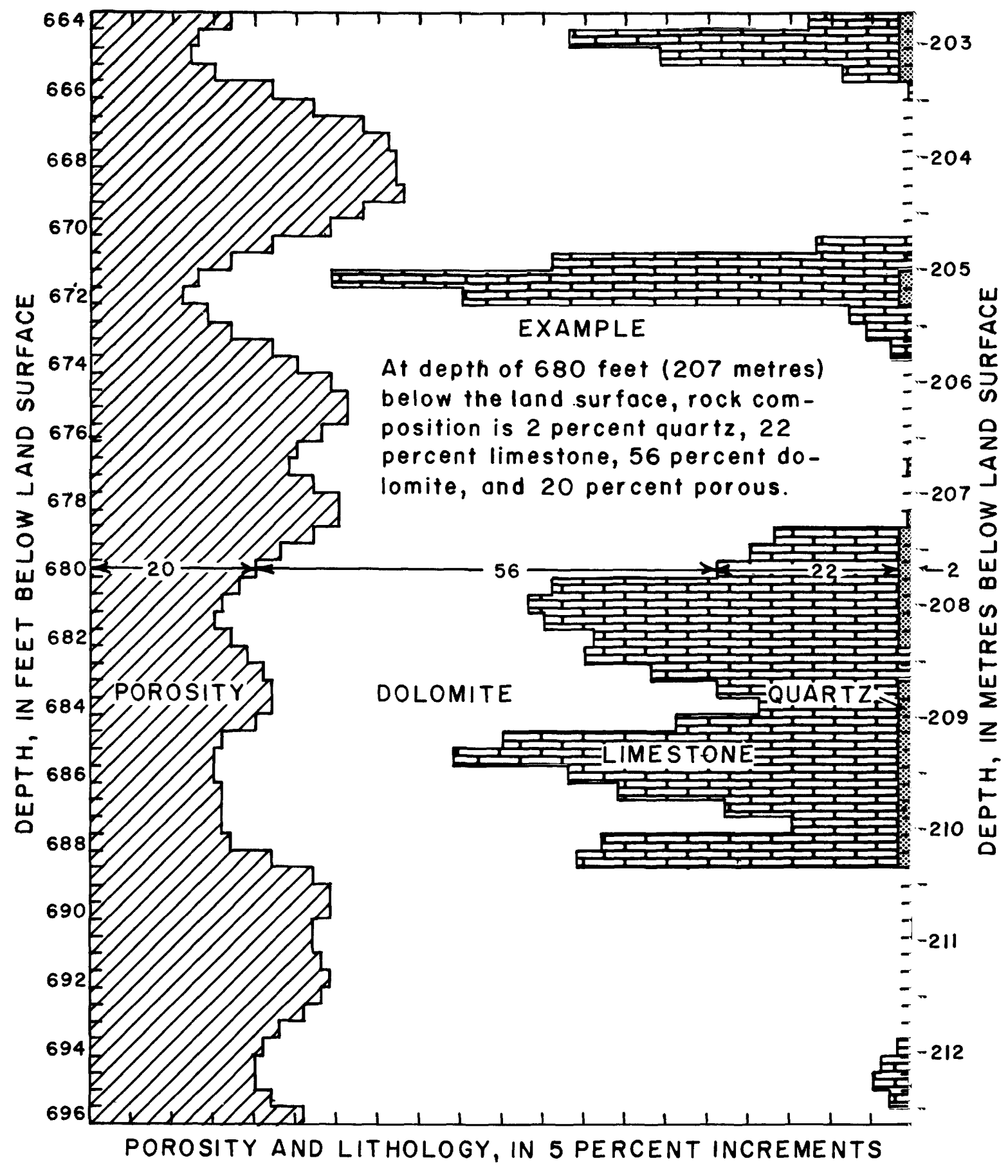

Figure 33.-Porosity and lithology os determined from an onalysis of geophysical well logs. 
Techniques of surface geophysics have not been widely used in the past for water-resource investigations due to the expensive equipment and special technical knowledge required. The Wyoming District of the U.S. Geological Survey has recently acquired the necessary equipment and expertise for conducting certain types of these studies, and these methods would be utilized for ground-water investigations in the study area.

Direct-current resistivity measurements can define the areal extent and vertical thickness of shallow aquifers, the porosity, waterlevel changes, and water-quality changes. Figure 34 is an example of interpreted resistivity measurements in alluvium. This figure show the interpreted resistivity values of a depth sounding in comparison with a gamma $10 \mathrm{~g}$ and with a geologic section made from drill-hole data. Figure 35 shows results of interpreted resistivity measurements in till where the extent, composition of the till, and a filled stream channel were defined (Frohlich and Head, 1972). Porosity can be estimated using resistivity of the formation and resistivity of the ground water (Schlumberger Limited, 1972).

Proposed sites for resistivity measurements are shown in figure 36. Sites in alluvial aquifers along major streams would be measured to aid in the determination of surface- and ground-water interrelations.

Measurements at EMRIA study sites would aid in the definition of groundwater supply and effects of mining on ground-water resources. Measurements in glacial deposits along the south side of the Wind River Range would aid in determining potential supply as well as interrelations with surface water. Gravity measurements at coal gasification and oil-shale retort sites could be used in estimating specific yield and the extent of cones of depression by measuring the change in mass near a well resulting from the withdrawal of fluids. The method has been described by E. L. Montgomery (written commun., 1971).

Surface seismic methods would be used to study deep aquifers. Interpretations of velocity analyses, amplitude analyses, reflectioncoefficient analyses and other routines can provide information concerning structure, thickness, and depth of geologic units. Figure 37 shows a typical velocity analysis of interpreted seismic data. Combining surface seismic data with borehole information allows for quantified interpolation between well control points where hydrologic and geologic parameters (porosity, lithology, etc.) are known. Seismic models would be defined in terms of hydrologic parameters and compared with borehole data. Seismic techniques would be used primarily between areas where well control exists or where well development is planned. 


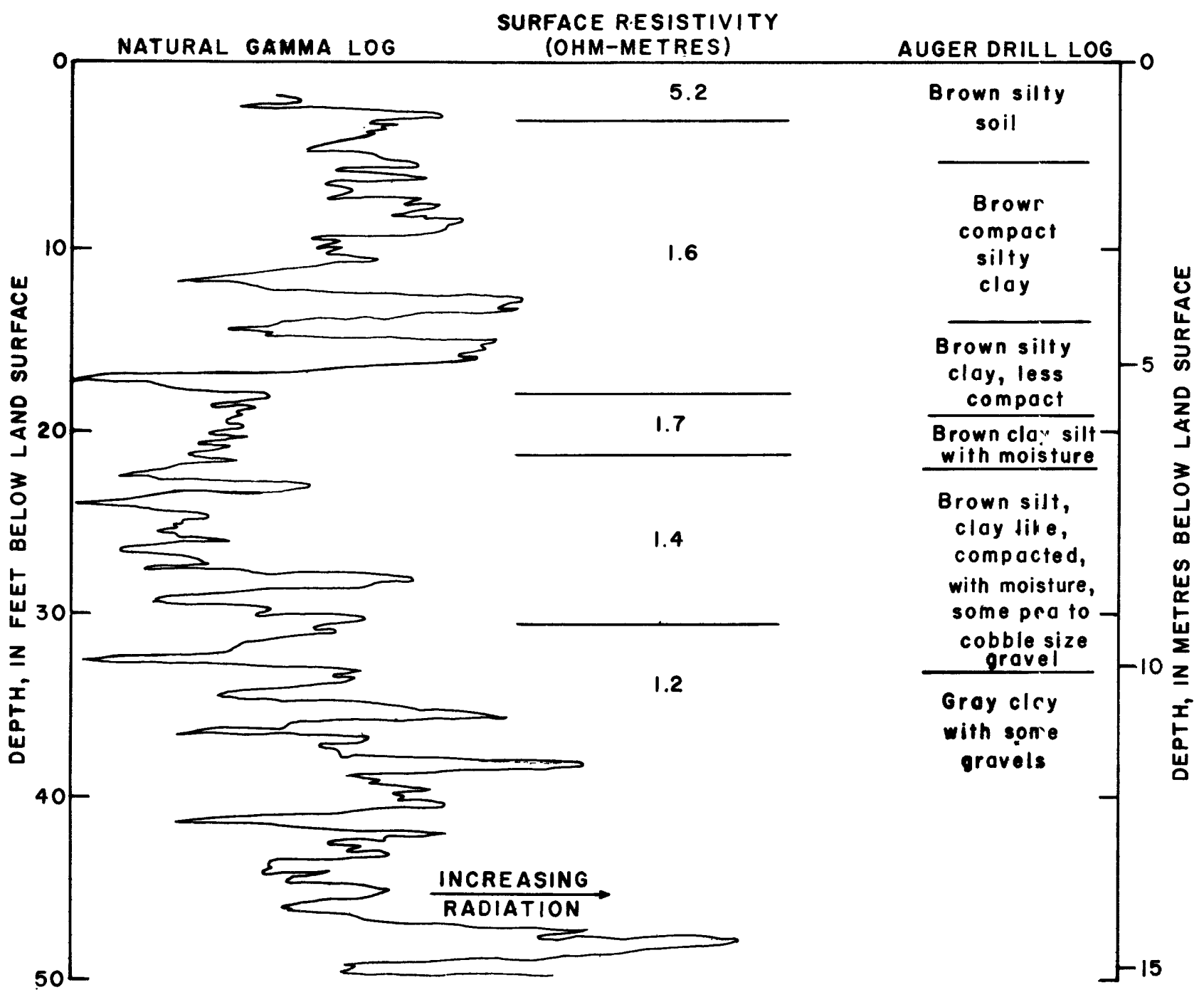

Figure 34. - Example of surface-resistivity measurements in alluvium compared to drill log and gamma log of a nearby hole. 


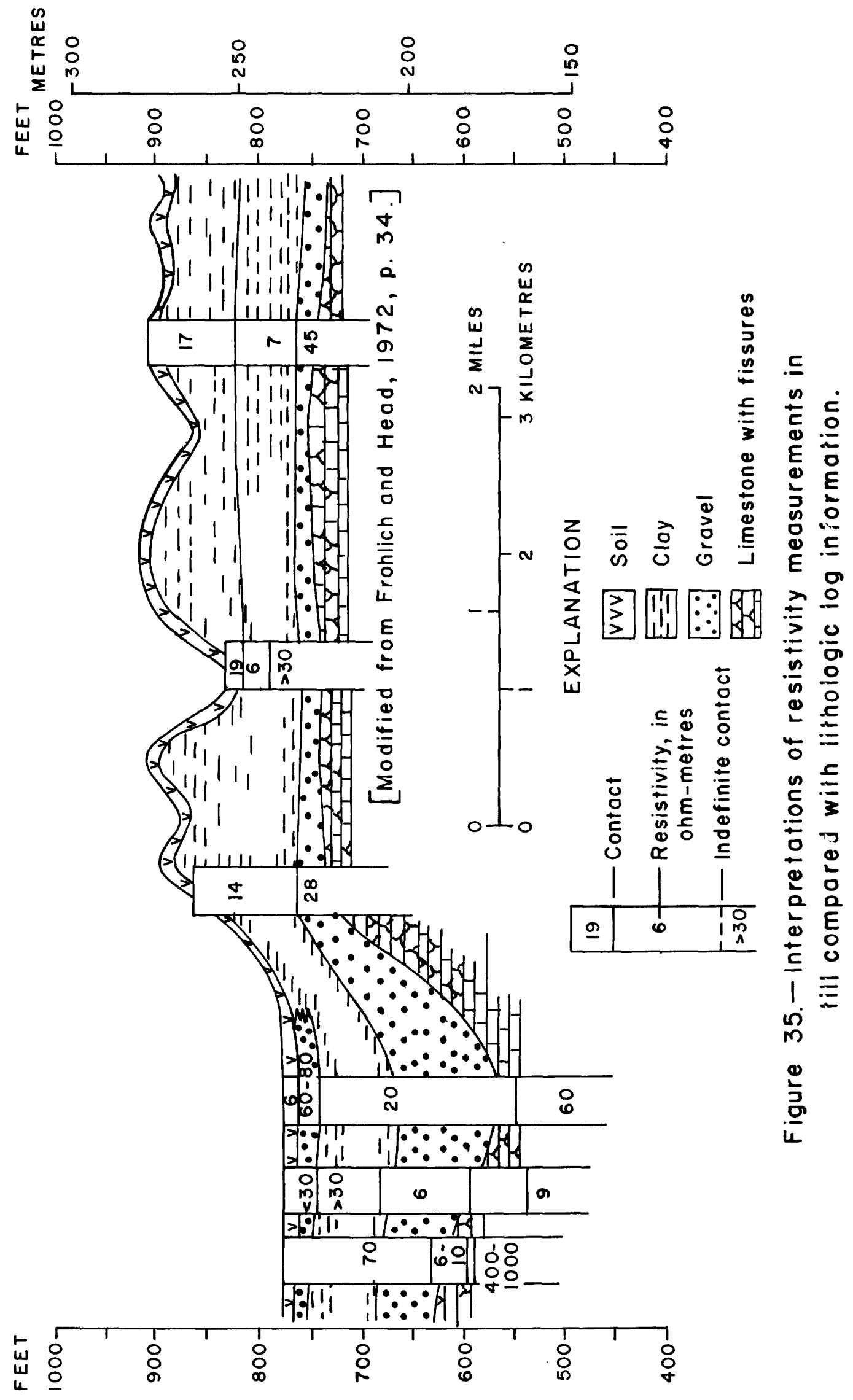




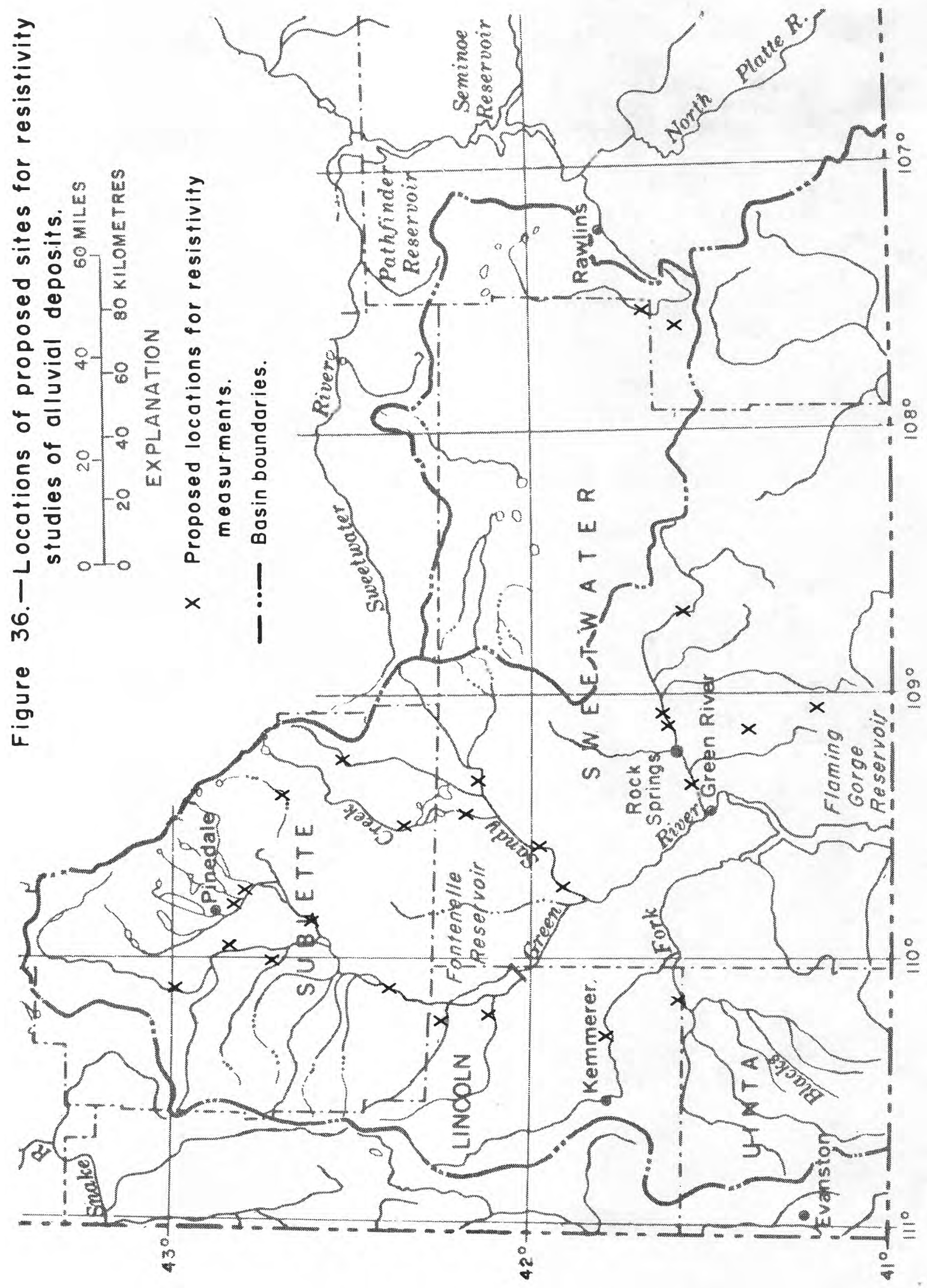




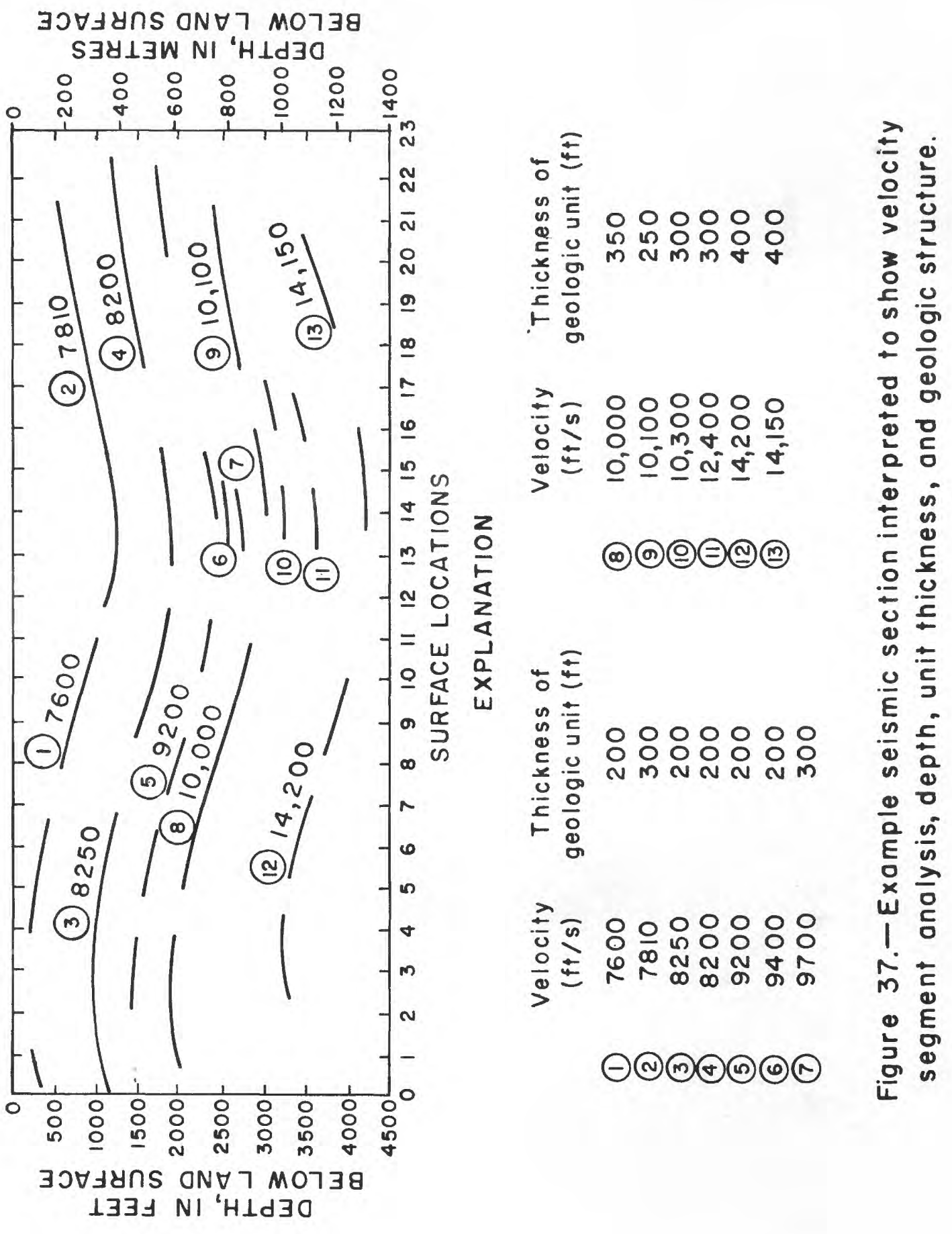


When the well inventory has been completed, a review would ro made of data deficiencies for the ground-water investigations. Hydrologic information would be obtained in data-deficient areas by geophysical and geochemical methods when possible. Where additional data are needed, existing drill holes would be developed for observation purposes. The oil and gas industries have abandoned many of their wells and tert holes, some of which could be developed as observation wells.

The U.S. Geological Survey has an extensive drilling effort planned in connection with coal development in the Great Divide Basin. The study group would obtain borehole data and establish observation wells in connection with this exploration study.

The trona companies have drilling operations as part of their flood-control program, as well as for exploratory drilling. Som? of these holes may be cased and used as observation wells.

A few shallow test holes would be drilled to provide control for the geophysical studies. The U.S. Geological Survey might occasionally participate in deepening an existing well or purchase rig time diring a drilling operation to deepen a well. 


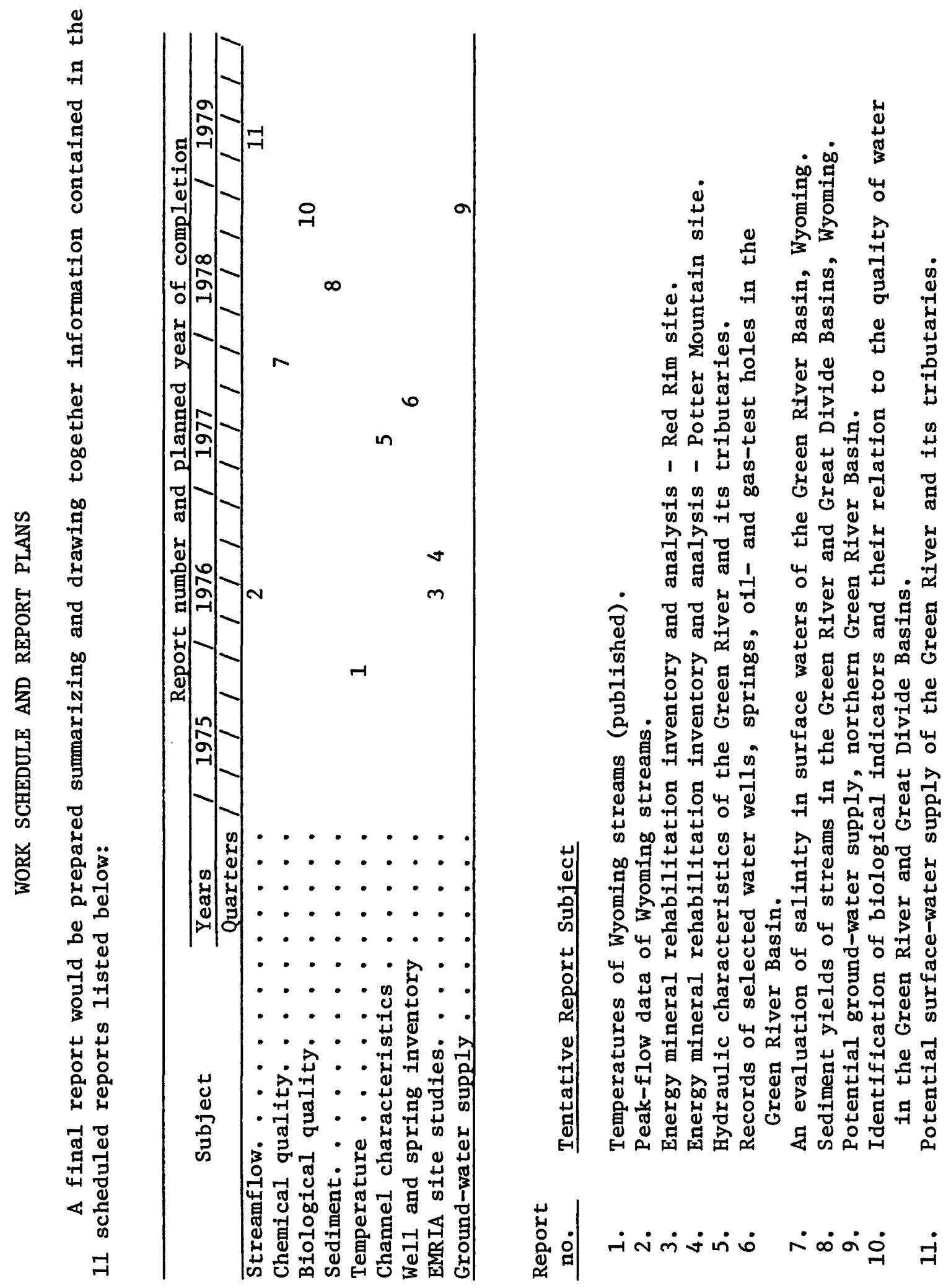




\section{REFERENCES}

American Public Health Association and others, 1971, Standard methods for the examination of water and wastewater [13th ed.]: New York, Am. Public Health Assoc., 874 p.

Anderman, G. G., 1956, Subsurface stratigraphy of the pre-Niobrara formations in the Green River Basin, Wyoming, in Wyoming stratigraphy: Casper, Wyoming Geol. Assoc., p. 49-68, 1 pl.

Balance, W. C., and Freudenthal, P. B., 1975, Ground-water levels in Wyoming, 1974; U.S. Geo1. Survey open-file rept., 186 p.

Berry, D. W., 1960, Geology and ground-water resources of the Rawlins area, Carbon County, Wyoming: U.S. Geo1. Survey Water-Supp1!r Paper 1458,74 p., 1 p1., 5 figs.

Binns, N. A., 1972, An inventory and evaluation of the game and fish resources of the Upper Green River in relation to current and proposed water development programs: Water Resources Research Institute rept., $196 \mathrm{p}$.

Boner, F. C., 1976, Water-resources investigations of the U.S. Geological Survey in the major coal and oil-shale areas of Wroming, 1975-76: U.S. Geol. Survey open-file rept. 48 p.

Bradley, W. H., 1945, Geology of the Wasahakie Basin, Sweetwater and Carbon Counties, Wyoming, and Moffat County, Colorado: U.S. Geol. Survey Oil and Gas Inv. Prelim. Map 32.

1961, Geologic map of a part of southwestern Wyoming and adjacent States: U.S. Geol. Survey Misc. Geol. Inv. Map I-332.

1964, Geology of Green River Formation and associated Eocene rocks in southwestern Wyoming and adjacent parts of Colorado and Utah: U.S. Geo1. Survey Prof. Paper 496-A, 86 p.

Bradley, W. H., and Eugster, H. P., 1969, Geochemistry and paleolimnology of the trona deposits and associated Authigenic minerals of the Green River Formation of Wyoming: U.S. Geo1. Survey Prof. Paper 496-B, 71 p., 2 pls.

Brown, D. L., 1971, Techniques for quality-of-water interpretation from calibrated geophysical logs, Atlantic coastal area: Ground rater, v. 9, July-Aug., p. 14 .

Burk, C. A., 1956, Stratigraphic summary of the pre-Niobrara formations in Wyoming, in Wyoming Stratigraphy, Part 1, Subsurface stratigraphy of the pre-Niobrara formations in Wyoming: Wyoming Geol. Assoc., p. 91-97. 


\section{REFERENCES--continued}

Cameron Engineers, 1969, Review and forecast, Wyoming mineral industries: Prepared for the Wyoming Natural Resource Board and the State Water Planning Program, 3 vols.

Crews, G. C., Barlow, J. A., Jr., and Haun, J. D., 1973, Natural gas resources, Green River Basin, Wyoming: Wyoming Geol. Assoc. Guidebook, 25th Ann. Field Conf., 1973, p. 103-113.

Culbertson, W. C., 1966, Trona in the Wilkins Peak Member of the Green River Formation, southwestern Wyoming: U.S. Geol. Survey Prof. Paper 550-B, p. B159-B164.

Dana, G. F., and Smith, J. W., 1973a, Black trona water, Green River Basin: Wyoming Geol. Assoc. Guidebook, 25th Ann. Field Conf., 1973, p. 153-156.

1973b, Artesian aquifer, New Fork Tongue of the Wasatch Fcrmation, Northern Green River Basin: Wyoming Geol. Assoc. Guidebook, 25th Ann. Field Conf., 1973, p. 201-208.

Dolene, M. R., 1973, The ecological considerations of Project Wagc 7 Wheel: Wyoming Geol. Assoc. Guidebook, 25th Ann. Field Conf., 1973, p. 215-223.

Emmett, W. W., 1972, The hydraulic geometry of some Alaskan streams south of the Yukon River: U.S. Geol. Survey open-file report, $102 \mathrm{p}$.

1975, The channels and waters of the upper Salmon River area, Idaho: U.S. Geol. Survey Prof. Paper 870-A, 116 p.

Frohlich, R. K., and Head, W. J., 1972, Methods of determining aquifer storage capacity and fresh-saline water interfaces by geoelectrical investigations: Missouri Water Resources Research Center prcject rept. A-046-Mo, p. 39.

Gilkey, N. M., and Stotelmeyer, R. B., 1967, Water requirements ard uses in Wyoming mineral industries: U.S. Bur. Mines Inf. Circ. $8 \approx 28$.

Glass, G. B., 1973, Summary of coal mining in Wyoming: Wyoming Geol. Assoc. Guidebook, 25th Ann. Field Conf., 1973, p. 115-129.

Gudim, C. J., 1956, Subsurface stratigraphy of the pre-Niobrara fcrmations along the eastern margin of the Great Divide and Washakie Basins, Wyoming, in Wyoming Stratigraphy, Part 1, Subsurface stratigraphy, of the pre-Niobrara formations in Wyoming: Wyoming Geol. Assoc., p. 69-75, 1 p1. 


\section{REFERENCES--continued}

Haun, J. D., 1961, Stratigraphy of post-Mesaverde Cretaceous rocks, Sand Wash Basin and vicinity, Colorado and Wyoming, in Symposium on Late Cretaceous rocks of Wyoming: Wyoming Geol. Assoc. Guidebook 16th Ann. Field Conf., p. 116-124.

Hansen, W. R., 1965, Geology of the Flaming Gorge area, Utah-ColoradoWyoming: U.S. Geo1. Survey Prof. Paper 490, 196 p.

Interagency 0il Shale Planning Pane1, 1975, Accelerated oil shale in situ research, a national program: U.S. Dept. of Int., 47 p.

Iorns, W. V., Hembree, C. H., and Oakland, G. L., 1965, Water resnurces of the Upper Colorado River Basin--Technical report: U.S. Geo1. Survey Prof. Paper 441, 370 p.

Klots, E. B., 1966, The new field book of freshwater 1ife: New York, G. P. Putnam's Sons, 398 p.

Leopold, L. B., and Emmett, W. W., 1976, Bedload measurements, East Fork River, Wyoming: [U.S.] Natl. Acad. Sci. Proc., v. 73, no. 4, p. 1000-1004.

Leopold, L. B., Wolman, M. G., and Miller, J. P., 1964, Fluvial processes in geomorphology: San Francisco and London, W. H. Freeman and Co., $522 \mathrm{p}$.

Leopold, L. B., and Maddock, Thomas, Jr., 1953, The hydraulic geonetry of stream channels and some physiographic implications: U.S. Geol. Survey Prof. Paper 252, 57 p.

Lines, G. C., and Glass, W. R., 1973, Water resources of the thrust belt of western Wyoming: U.S. Geol. Survey open-file rept. [HA-539].

Love, J. D., 1961, Definition of Green River, Great Divide, and Washakie Basins, southwestern Wyoming: Am. Assoc. Petroleum Geologists Bull., v. 45, no. 10, p. 1749-1755.

Lowham, H. W., Kircher, J. E., and Boner, F. C., 1975, Temperatures, of Wyoming Streams: Wyoming State Engineer's office, Wyoming Water Planning Program rept. no. 15.

Madison, R. J., and Wadde11, K. M., 1973, Chemical quality of surface water in the Flaming Gorge Reservoir area, Wyoming and Utah: U.S. Geo1. Survey Water-Supply Paper 2009-C, 18 p.

McKee1, B. K., 1973, Uranium in the Great Divide Bas1n, Wyoming: Wyoming Geo1. Assoc. Guidebook, 25th Ann. Field Conf., 1973, p. 131-137. 


\section{REFERENCES--continued}

Miller, D. N., Jr., 1973, Wyoming's resources--Green River Basin: Wyoming Geol. Assoc. Guidebook, 25th Ann. Field Conf., 1973, p. 23-26.

Montgomery, E. L., 1971, Determination of specific yield using gravity measurements: Am. Geophysical Union, Apr. 1971, p. 4.

0'Connell, D. L., 1969, Surface-water discharge and ground-water levels in the East Fork River area, Sublette County, Wyoming: U.S. Geol. Survey open-file rept., $77 \mathrm{p}$.

Oriel, S. S., 1969, Geology of the Fort Hill quadrangle, Lincoln County, Wyoming: U.S. Geo1. Survey Prof. Paper 594-M, 40 p. 2 pl.

Osterwald, F. W., Osterwald, D. B., Long, J. S., and Wilson, W. H., 1959, Mineral resources of Wyoming: Wyoming Geol. Survey Bu11. 50, 259 p.

Pipringos, G. N., 1968, Correlation and nomenclature of some Triassic and Jurassic rocks in south-central Wyoming: U.S. Geol. Survey Prof. Paper 594-D, 26 p.

Price, Donald, and Arnow, Theodore, 1974, Summary appraisals of the Nation's ground-water resources--Upper Colorado Region: U.S. Geol. Prof . Paper 813-C, 40 p., 2 pl.

Ringen, B. H., 1973, Records of ground-water levels in Wyoming, 1940-71: Wyoming State Engineer's office, Wyoming Water Planning Program rept. no. 13 .

Ringen, B. H., 1974, Records of ground-water levels in Wyoming, 1972-73: Wyoming State Engineer's office, Wyoming Water Planning Program rept. no. 13 , supplement no. 1 .

Robinove, C. J., and Cummings, T. R., 1963, Ground-Water resources and geology of the Lyman-Mountain View area, Uinta County, Wyoming: U.S. Geol. Survey Water-Supp1y Paper 1669-E, 43 p.

Root, F. K., Glass, G. B., and Lane, D. W., 1973, Sweetwater County, Wyoming, geologic map atlas and summary of economic mineral rasources: Geo1. Survey of Wyoming County Resource Series no. 2.

Schlumberger Limited, 1972, Log interpretation, v. 1--princ1ples: New York, $113 \mathrm{p}$.

Schwoerbel, J., 1972, Methods of hydrobiology--fresh water biology: Toronto, Pergamon Press., 1st ed., 200 p. 
Slack, K. V., Averett, R. C., Greeson, P. E., and Lipscomb, R. G., 1973, Methods for collection and analysis of aquatic biological and microbiological samples: U.S. Geol. Survey Techniques Water-Resources Inv., book 5, chap. A4, 165 p.

Smith, J. H., 1965, A summary of stratigraphy and paleontology, upper Coloradan and Montanan Groups, south-central Wyoming, northeastern Utah, and northwestern Colorado: Wyoming Geol. Assoc. Guidelook, 19th Ann. Field Conf., 1965, p. 13-26, p1. 4.

Steele, T. D., 1970, A study of the chemical quality of streamflor in Arkansas--Phase I: U.S. Geol. Survey open-file report, 89 p.

1974, Harmonic analysis of stream temperature: Reston, Virginia, U.S. Geo1. Survey Computer Contribution, December 1974, $246 \mathrm{p}$.

Surdam, R. C. and Wolfbauer, C. A., 1973, Origin of oil shale in the Green River Formation, Wyoming: Wyoming Geo1. Assoc. Guidebnok, 25th Ann. Field Conf., 1973, p. 207-208.

U.S. Bureau of Census, 1970, Census of Population, Number of Inhalitants, rept. no. PC(1)--A52 Wyoming, $19 \mathrm{p}$.

U.S. Bur. of Reclamation, Region 4, 1972, Alternative plans for water resources developments, Green River Basin, Wyoming: Special rept.

1975, Sublette Project investigation, resource base appendix.

U.S. Dept. of Commerce, 1973, Monthly normals of temperature, precipitation, and heating and cooling degree days 1941-70; Climatography of the U.S. No. $81,8 \mathrm{p}$.

U.S. Dept. of the Interior, 1973, Final environmental statement for the prototype oil-shale leasing program: Washington, U.S. Govt. Printing office, $6 \mathrm{v}$.

1975, Quality of water, Colorado RIver Basin:

Progress rept. no. 7, $195 \mathrm{p}$.

Upper Colorado Region Comprehensive Framework Study, 1971, Main report: 18 app.

Vince, J. D., and Prichard, G. E., 1959, Geology and uranium occulrences in the Miller Hill area, Carbon County, Wyoming: U.S. Geol. Survey Bu11. 1074-F, p. 201-239, pls. 14-20, f1gs. 10-14. 
Weber, C. I., 1973, Biological field and laboratory methods for measuring the quality of surface waters and effluents: Cincinnati, National Environmenta1 Research Center, 186 p.

Weimer, R. J., 1965, Stratigraphy and petroleum occurrences, Almord and Lewis Formations (Upper Cretaceous), Wamsutter Arch, Wyoming: Wyoming Geol. Assoc. Guidebook, 19th Ann. Field Conf., 1965, p. 65-80.

Welder, G. E., 1968, Ground-water reconnaissance of the Green River Basin, southwestern Wyoming: U.S. Geol. Survey Hydrol. Inv. Atlas PA-290.

Welder, G. E., and McGreevy, L. J., 1966, Ground-Water reconnaissance of the Great Divide and Washakie Basins and some adjacent areas, southwestern Wyoming: U.S. Geol. Survey Hydrol. Inv. Atlas HA-21S.

West, S. W., 1975, The role of ground water in resource planning in the western United States: Western U.S. Water Plan open-f1le rept. no. 74-125, $177 \mathrm{p}$.

Wyoming Dept. of Economic Planning and Development, 1974, Wyoming Timber Industries Directory: $28 \mathrm{p}$.

Wyoming Highway Dept, 1970, State of Wyoming: Highway map, 1 shee.t.

Wyoming Water Planning Program, 1965, Average growing season for forage crops in Wyoming: Wyo. State Engr. map, 1 sheet.

1965, Mean annual precipitation of Wyoming

as of 1965: Wyo. State Engr. map, 1 sheet.

1970, Water and related land resources of

the Green River Basin, Wyoming: Wyoming State Engineer's office, Rept, no. 3 and addendum, $167 \mathrm{p}$. 